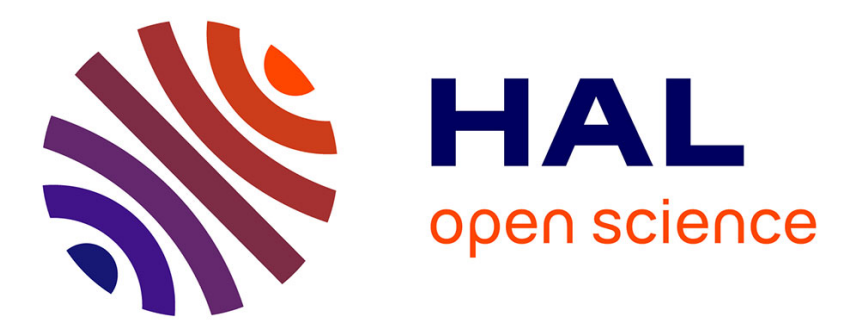

\title{
Erufosine (ErPC3) Cationic Prodrugs as Dual Gene Delivery Reagents for Combined Antitumor Therapy
}

Boris Gaillard, Cendrine Seguin, Jean-serge Remy, Françoise Pons, Luc Lebeau

\section{- To cite this version:}

Boris Gaillard, Cendrine Seguin, Jean-serge Remy, Françoise Pons, Luc Lebeau. Erufosine (ErPC3) Cationic Prodrugs as Dual Gene Delivery Reagents for Combined Antitumor Therapy. Chemistry A European Journal, 2019, 25 (68), pp.15662-15679. 10.1002/chem.201903976 . hal-02361375

\section{HAL Id: hal-02361375 https://hal.science/hal-02361375}

Submitted on 25 Nov 2020

HAL is a multi-disciplinary open access archive for the deposit and dissemination of scientific research documents, whether they are published or not. The documents may come from teaching and research institutions in France or abroad, or from public or private research centers.
L'archive ouverte pluridisciplinaire HAL, est destinée au dépôt et à la diffusion de documents scientifiques de niveau recherche, publiés ou non, émanant des établissements d'enseignement et de recherche français ou étrangers, des laboratoires publics ou privés. 


\title{
Erufosine (ErPC3) Cationic Prodrugs as Dual Gene Delivery Reagents for Combined Antitumor Therapy
}

\author{
Boris Gaillard, Cendrine Seguin, Jean-Serge Remy, Françoise Pons, and Luc Lebeau *[a]
}

\begin{abstract}
Sixteen cationic prodrugs of the antitumor alkylphospholipid (APL) erufosine were rationally synthesized to provide original gene delivery reagents with improved cytotoxicity profile. The DNA complexation properties of these cationic lipids were determined and associated transfection rates were measured. Besides, the self-assembly properties of the pro-erufosine compounds were investigated and their critical aggregation concentration was determined. Their hydrolytic stability under $\mathrm{pH}$ conditions mimicking the extracellular environment and the late endosome milieu was measured. Hemolytic activity and cytotoxicity of the compounds were investigated. The results obtained in various cell lines demonstrate that the prodrugs of erufosine display antineoplastic activity similar to that of the parent antitumor drug but are not associated with hemolytic toxicity, a dose-limiting side effect of APLs and a major obstacle to their use in anticancer therapeutic regimen. Furthermore, using lipoplexes prepared from a prodrug of erufosine and a plasmid DNA encoding a pro-apoptotic protein (TRAIL), evidence was provided for selective cytotoxicity towards tumor cells while non-tumor cells were resistant. This study demonstrates that the combination approach involving well tolerated erufosine cationic prodrugs and cancer gene therapy holds significant promise in tumor therapy.
\end{abstract}

\section{Introduction}

Alkylphospholipids (APLs) constitute a new class of antitumor drugs which do not interact directly with DNA but target the cell membrane where they accumulate and interfere with lipid metabolism and signaling pathways, thereby affecting the growth, cell cycle progression, and survival of tumor cells. ${ }^{[1]}$ APLs originally derived from lysophosphatidylcholines (lysoPCs), ${ }^{[2]}$ endogenous cell membrane components that result from hydrolysis of phosphatidylcholines (PCs) by phospholipases. Since lysoPCs are not stable and become inactivated, either by

[a] Dr. B. Gaillard, C. Seguin, Dr. J.-S. Remy, Prof. Dr. F. Pons, Dr. L. Lebeau

Laboratoire de Conception et Application de Molécules Bioactives UMR 7199 CNRS - Université de Strasbourg

Faculté de Pharmacie, 74 route du Rhin - BP 60024

67401 Illkirch (France)

E-mail: llebeau@unistra.fr

Supporting information for this article is given via a link at the end of the document. the action of acyltransferase into PCs, or by lysophospholipases into glycerophosphocholine, efforts have been devoted to the synthesis of metabolically stable analogs to act as modulators of signaling pathways and alter biochemical routes (Figure 1). Edelfosine (1-O-octadecyl-2-O-methyl-rac-glycero-3-phosphocholine), the first molecule of this drug class was described in the late 60 s. $^{[3]}$ Though it was proven effective in in vitro and in vivo antiproliferative assays, clinical use was limited mainly due to metabolic instability, high hemolytic activity, and gastrointestinal toxicity. ${ }^{[4]}$ Ilmofosine (1-hexadecylthio-2-methoxymethyl-racglycero-3-phosphocholine), a thio-ether analog was proposed but, although it revealed as an effective inhibitor of cell proliferation, the chemical modification did not alter significantly its metabolic stability or cytotoxic effect. ${ }^{[5]}$ In the late $80 \mathrm{~s}$, miltefosine (HePC, hexadecylphosphocholine), a new analog lacking the glycerol moiety, was discovered and brought APLs to a clinical important level. ${ }^{[6]}$ Similarly to the earlier APLs, miltefosine presented appreciable in vitro antiproliferative activity but was found highly hemolytic and provoked marked gastrointestinal toxicity. Consequently, the clinical use of miltefosine has been limited mainly to the topical treatment of skin metastases in patients with breast cancer. To improve the therapeutic potency of APLs, replacement of the choline moiety in miltefosine by a dimethyl piperidinium group resulted in perifosine (octadecyl-1(dimethylpiperidinio-4-yl)-phosphate). ${ }^{[7]}$ Stability and half-life of the compound were significantly increased, preventing rapid metabolic degradation.$^{[8]}$ However, hemolytic activity still was high and toxicity profile after oral administration was similar to that of miltefosine with no successful outcome in the treatment of various

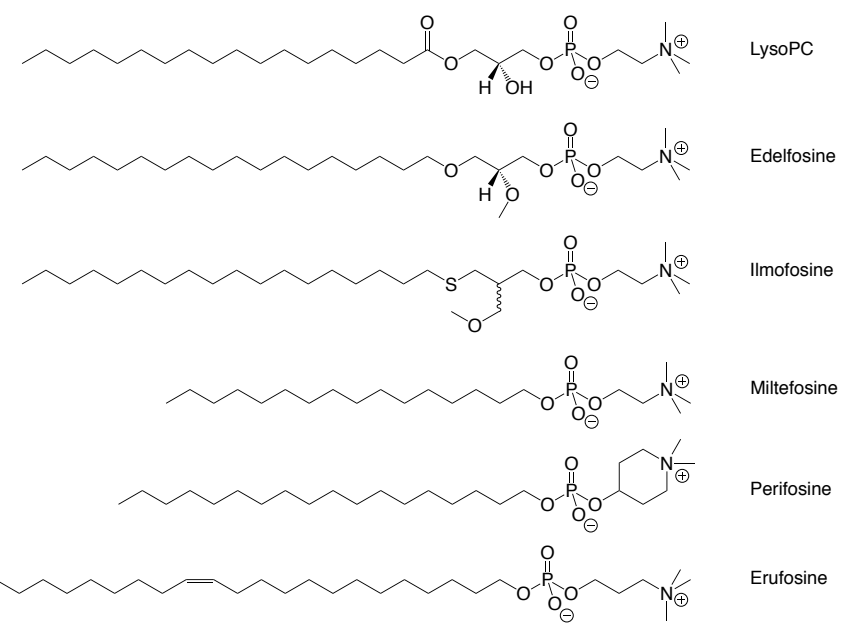

Figure 1. Structure of 18:0 lysoPC and APLs. 
cancers. ${ }^{[9]}$ As a member of the fourth generation of APLs, erufosine (erucylphosphohomocholine) resulted from the simultaneous introduction of an $\omega$-9-cis-unsaturated alkyl chain with 22 carbon atoms and a homocholine moiety on the phosphate group of the APL. Extension of the hydrophobic chain decreased aqueous solubility of the molecule that likely selfassembles into lamellar structures instead of micelles, as was claimed for a closely related structural analog. ${ }^{[10]}$ As a consequence the hemolytic potential was significantly reduced, which enabled intravenous (iv) administration that was not feasible with previous APLs. ${ }^{[11]}$

Due to their particular mechanism of action targeting the cell membrane, APLs may be useful in combination with other chemotherapy agents and radiation therapy. Several clinical studies have reported significant benefits of combining APLs with diverse antineoplastic agents (cytarabine, gemcitabine, capecitabine, idarubicin, doxorubicin, etoposide, docetaxel, staurosporine, sorafenib, lenalidomide-dexamethasone, bortezomibdexamethasone, temsirolimus....). ${ }^{[12]}$ Besides, some of the pathways by which APLs lead to cytotoxicity have been shown to influence radiosensitivity or radioresistance of tumor cells, which resulted in successful clinical outcome of the combination of APLs with radiotherapy. ${ }^{[13]}$ On the other hand, there are only very few reports on the combination of APLs with cancer gene therapy. In 2003, Zeisig et al. described gene transfer with liposomal formulations incorporating APLs as helper lipids, ${ }^{[14]}$ assuming that APLs may promote the transmembrane transport of the plasmidlipid complex (lipoplex) into the target cell due to their "detergentlike properties". Introduction of $2 \%$ tetradecylphosphocholine (TPC), a lower carbon homologue of miltefosine, in the lipoplexes improved transfer efficiency of the LacZ gene into HCT15 and HCT116 human colon carcinoma cells up to $43 \%$. Similarly, Settelen et al. reported the intratumoral co-administration of naked DNA with miltefosine. ${ }^{[15]}$ Though this non condensingplasmid formulation failed to promote transgene expression in vitro, it showed a ten-fold increased reporter gene expression with increasing miltefosine concentration in Renca tumor following intratumor injection, as compared to plasmid alone. More recently, perifosine was used in combination with siRNA lipoplexes silencing C-FLIP, an inhibitory protein that blocks the extrinsic pathway of apoptosis by preventing caspase- 8 activation by death receptors. ${ }^{[16]}$

In the course of our research towards developing new nucleic acid carriers, we were attracted by APLs as they can be conveniently transformed into cationic lipids, i.e., molecules that may be potentially powerful nucleic acid condensing reagents. Therefore, the transformation of an APL into a phosphotriester derivative generates a net positive charge on the molecule. This derivative can thus establish electrostatic interactions with negatively charged nucleic acid and promote its condensation into discrete particles as required for cell uptake and intracellular delivery through endocytosis.[17] Furthermore, when the transformation of the APL compound is reversible and sensitive, e.g., to a pH or enzyme stimulus as met along the endo-lysosome pathway, in situ regeneration of the zwitterionic APL may be expected. Intermolecular electrostatic interaction between the ammonium headgroup of the newly unmasked APL molecule and nucleic acid phosphates then becomes thermodynamically disfavored, as compared to intramolecular zwitterionic interaction. This process thus triggers and facilitates nucleic acid decondensation, which is required for nucleic acid processing by the cell translation machinery. Besides, from the sorting endosomes, most amphiphilic molecules enter the endocytic recycling pathway. ${ }^{[18]}$ Lipid recycling at the plasma membrane is a highly dynamic and effective process, ${ }^{[19]}$ and antiproliferative APL produced in situ from the nucleic acid carrier is prone to trafficking at the plasma membrane where it can operate intrinsic apoptotic activity. ${ }^{[20]}$ Starting from erufosine, one of the most promising APLs to date, original lipid constructs were thus imagined for simultaneously implementing gene therapy and chemotherapy. A series of 16 biolabile cationic lipids have been designed which can regenerate erufosine in situ under a chemical or enzyme stimulus. The properties of these erufosine prodrugs as gene delivery reagents have been investigated using a luciferase reporter gene assay, and their intrinsic cytotoxicity has been determined. Finally, using a plasmid DNA encoding the tumor necrosis factor-related apoptosis-inducing ligand (TRAIL), the in vitro synergistic antiproliferative effect of TRAIL and erufosine prodrugs has been examined.

\section{Results and Discussion}

\section{Design of erufosine prodrugs as gene carriers}

Erufosine is currently the most promising APL, essentially due to its structure with a 22-carbon long chain and an $\omega$-9-cis-double bond that imposes formation of lamellar instead of micellar structures in aqueous solution. This results in a significant decrease in hemolytic activity as compared to other APLs and allows intravenous administration at clinically relevant high doses. ${ }^{[21]}$ Transformation of erufosine into a cationic species with nucleic acid complexation ability can be straightforwardly achieved through esterification into phosphotriester compounds. However, non-selective hydrolysis of such compounds into phosphodiesters would produce a mixture of erufosine together with two other phosphodiesters resulting from the alternate leaving of the homocholine or heneicosenol phosphate substituent. Consequently, to favor formation of the parent APL upon hydrolysis of these phosphotriesters, it is valuable to introduce a (bio)labile substituent at the phosphate that may be preferentially removed under a chemical or enzyme stimulus. Based on previous reports on the development of DOPC-based phosphoacetals as labile cationic lipids for gene delivery, ${ }^{[22]}$ we aimed to extend this methodology to produce potent prodrugs of erufosine (Figure 2). Consequently, erufosine was derivatized to incorporate various $n$-carbon alkyl chains connected to the phosphate group, directly or through a mixed acetal moiety. Compounds were developed both in the ester (compounds noted $\mathbf{E}_{\mathrm{En}_{n}}$ ) and carbonate (compounds noted $\mathbf{E}_{\mathrm{cn}}$ ) mixed phosphoacetal series to modulate their hydrolytic stability which presumably at least partly determines their potency as gene delivery reagents and the rate of erufosine release in situ. Pursuing the same idea, a methyl substituent was introduced on the acetal bridge (compounds noted $E_{E^{\prime} n}$ and $E_{C^{\prime} n}$ ) as it was recently demonstrated 


Erufosine

extracellular and late endosome environment, i.e., $\mathrm{pH} 7.4$ and 4.5, respectively. This was achieved through ${ }^{31} \mathrm{P}-\mathrm{NMR}$ measurements. As phosphotriesters and phosphodiesters display ${ }^{31} \mathrm{P}$ chemical shifts differing by ca. 5-6 ppm, it is possible to precisely monitor the quantity of both species in a sample and thus determine the hydrolysis rate of a phosphotriester in solution. The pro-APLs were formulated into liposomes by using an injection technique, ${ }^{[23]}$ at $\mathrm{pH} 7.4$ and 4.5 , and incubated at $25^{\circ} \mathrm{C}$. Periodical acquisition of the ${ }^{31} \mathrm{P}-\mathrm{NMR}$ spectra using a 4-sec pulse cycle (enabling for quantitative determination of the phosphorylated species through the integration of their resonance signal) was carried out and the rate of hydrolysis was determined (Table 1). Whatever the compound investigated, only one single ${ }^{31} \mathrm{P}$ resonance did appear during the course of the experiments. This signal did correspond to that of erufosine and no other phosphodiester could be detected. This confirmed that hydrolysis selectively occurred at the phosphoacetal center. Consistently, phosphotriester $\mathbf{E}_{12}$ lacking acetal moiety revealed fully stable both under neutral and acidic conditions, even after an incubation period of 31 days. All the other erufosine derivatives were sensitive to hydrolysis. As a general trend, hydrolysis was quicker at $\mathrm{pH} 7.4$ than at $\mathrm{pH}$ 4.5. This indicates that mixed acetals of carboxylic or carbonic and phosphoric esters display a reactivity that is different from that of dialkyl acetals which are highly labile species in acidic media, and is consistent with results reported for other phosphoacetals. ${ }^{[22 e, f]}$

Figure 2. Synthetic route to and structure of the 16 erufosine prodrugs investigated in this work.

that it can significantly improve the hydrolysis rate of phosphoacetal compounds. ${ }^{[22 f]}$ All these compounds were producedaccording to the same protocol, reacting erufosine with a large excess of electrophilic reagent (8 eq.) in boiling anhydrous chloroform for $24 \mathrm{~h}$. The reaction yields were highly variable (6 to $97 \%$ ) and did depend on the reactivity of the electrophilic reagents and on the stability of the reaction products, especially for compound $\mathbf{E}_{2}$. Due to the presence of two stereogenic centers, compounds displaying a methyl-substituted acetal bridge $\left(\mathbf{E}_{\mathrm{E}^{\prime} 12}, \mathbf{E}_{\mathrm{C}^{\prime} 12}, \mathbf{E}_{\mathrm{E}^{\prime} 18: 1}\right.$, and $\left.E_{C^{\prime} 18: 1}\right)$ were produced as a mixture of four diastereomers. When possible, the couples of enantiomers were separated for analytic purpose, but evaluations (vide infra) were performed on the original mixture of the four isomers.

\section{Hydrolytic stability of the erufosine prodrugs}

Aqueous formulation of the erufosine prodrugs results in the formation of nanosized lipid aggregates that most likely are internalized by cells through the endocytic route. To express the expected intrinsic antitumor activity (vide infra), these compounds need to be transformed back into erufosine which is the bioactive species. Hydrolysis of the erufosine prodrugs may occur under a chemical stimulus, e.g., acidification of the environment as observed in the endosome during its maturation process, or may be under the control of hydrolytic enzymes that are abundantly introduced into the endosome compartment upon fusion with lysosomes. To get an insight into regeneration of erufosine from its prodrugs, we determined the hydrolytic stability of the proerufosine compounds under $\mathrm{pH}$ conditions mimicking the

Table 1. Hydrolytic stability of the pro-erufosine compounds. Compounds formulated into liposomes were incubated at $25^{\circ} \mathrm{C}$ and hydrolysis at $\mathrm{pH} 7.4$ and 4.5 was monitored by quantitative ${ }^{31} \mathrm{P}-\mathrm{NMR}$ measurements. $\mathrm{H}_{120}$ refers to the extent of hydrolysis (\%) after incubation over $120 \mathrm{~h}$. When possible, time required for $50 \%$ hydrolysis $\left(t_{1 / 2}\right)$ was calculated from the theoretical curve fitting with the experimental data.

\begin{tabular}{|c|c|c|c|c|c|}
\hline \multirow{2}{*}{ Entry } & \multirow{2}{*}{ Compound } & \multicolumn{2}{|c|}{$\mathrm{H}_{120}(\%)$} & \multicolumn{2}{|c|}{$t_{1 / 2}(\mathrm{~h})$} \\
\hline & & $\mathrm{pH} 7.4$ & $\mathrm{pH} 4.5$ & $\mathrm{pH} 7.4$ & $\mathrm{pH} 4.5$ \\
\hline 1 & $E_{12}{ }^{[a]}$ & 0 & 0 & - & - \\
\hline 2 & $\mathrm{E}_{\mathrm{E} 12}$ & 14 & 2 & - & - \\
\hline 3 & $E_{E^{\prime} 12}$ & 56 & 53 & 96 & 100 \\
\hline 4 & $E_{c_{12}}$ & 8 & 1 & - & - \\
\hline 5 & $E_{C^{\prime} 12}$ & 6 & 5 & - & - \\
\hline 6 & $E_{E 18: 1}$ & 23 & 18 & - & - \\
\hline 7 & $E_{E^{\prime} 18: 1}$ & 56 & 54 & 96 & 104 \\
\hline 8 & $E_{c 18: 1}$ & 10 & 0 & - & - \\
\hline 9 & $E_{C^{\prime} 18: 1}$ & 4 & 6 & - & - \\
\hline 10 & $\mathrm{E}_{\mathrm{E} 2}$ & - & - & - & - \\
\hline 11 & $\mathrm{E}_{\mathrm{E} 6}$ & 18 & 8 & - & - \\
\hline 12 & $E_{E 8}$ & 16 & 1 & - & - \\
\hline 13 & $E_{E 10}$ & 16 & 2 & - & - \\
\hline 14 & $E_{E 14}$ & 14 & 2 & - & - \\
\hline 15 & $\mathrm{E}_{\mathrm{E} 16}$ & 16 & 2 & - & - \\
\hline 16 & $\mathrm{E}_{\mathrm{E} 18}$ & 14 & 3 & - & - \\
\hline
\end{tabular}

[a] No hydrolysis was observed after an incubation period of 31 days. 
Based on these former reports, introduction of a methyl substituent on the acetal bridge was expected to improve the hydrolysis rate of the erufosine prodrugs. This however only held true in the ester series and $\mathrm{E}_{\mathrm{E}^{\prime} 12}$ and $\mathrm{E}_{\mathrm{E}^{\prime} 18: 1}$ indeed hydrolyzed faster than $\mathrm{E}_{\mathrm{E}_{12}}$ and $E_{E 18: 1}$, respectively. In the carbonate series, compounds were significantly more resistant to hydrolysis and introduction of a methyl substituent on the acetal bridge had only little effect, if any, on the rate of the hydrolytic reaction $\left(\mathrm{E}_{\mathrm{C}^{\prime 12}} v s . \mathrm{E}_{\mathrm{C}_{12} \text {, and }} \mathrm{E}_{\mathrm{C}^{\prime 18: 1}} \mathrm{vs}\right.$. $E_{C 18: 1)}$. With regards to the influence of the length of the pendant arm tethered to erufosine through the acetal linker on the hydrolysis rate, no significant difference was observed, except for $\mathrm{E}_{\mathrm{E} 6}$ that revealed $\mathrm{ca}$. four times more labile than higher homologs under acidic conditions. For technical reasons, we could not measure the hydrolytic stability of the lower homolog $\mathrm{E}_{\mathrm{E} 2}$. Though these results allowed a comparison of the hydrolytic stability of the erufosine prodrugs, it must be kept in mind that it only projected an incomplete and truncated image of the in cellulo stability of these compounds, as in situ enzymatic hydrolysis of the pro-erufosine compounds most probably occurs much faster than "purely" pH-controlled chemical hydrolysis, as was reported with other phosphoacetals. ${ }^{[22 c]}$

\section{Lipoplex formation and characterization}

The ability of the erufosine prodrugs to interact electrostatically with nucleic acids and form complexes was studied by conventional electrophoretic DNA retardation assay, in which a full retard of plasmid DNA (pDNA) is observed at a lipid/pDNA phosphate ratio (N/P) corresponding to electroneutrality of the complexes. The erufosine prodrugs generally led to a full pDNA complexation at N/P $>1.2-2.0$ as illustrated for compound $E_{E 12}$ in Figure 3. In the case of $E_{\mathrm{E} 2}$ however, electroneutrality was not reached even at N/P 4, presumably because this compound was too labile (vide supra) and was partly hydrolyzed during gel migration. The size (hydrodynamic diameter) and charge (zeta potential, $\zeta$ ) of the lipoplexes prepared at a N/P ratio of 3 with one molar equivalent of DOPE were investigated by DLS (Table 2). Most lipoplexes displayed a size in the range of $100-150 \mathrm{~nm}$. Noteworthy, introduction of an unsaturated chain on the phosphate group of erufosine, regardless of the linker, translated into the formation of significantly larger lipoplexes $(250-600 \mathrm{~nm}$, entry 6-9). As could be expected considering electrophoretic behavior, nearly all lipoplexes were highly positively charged at $\mathrm{N} / \mathrm{P} 3, \zeta$ values ranging from +36 to $+54 \mathrm{mV}$. Again, $E_{\mathrm{E} 2 \text {-based }}$

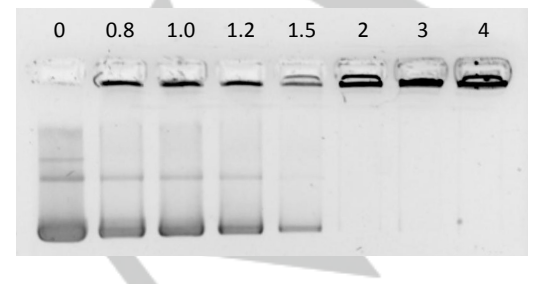

Figure 3. pDNA binding ability of pro-erufosine $E_{E 12}$ at increasing N/P ratio $(0$ to 4). Lipoplexes were prepared by mixing $0.8 \mu \mathrm{g}$ of plasmid DNA (pCMV-Gluc) and increasing amounts of pro-erufosine in $10 \mathrm{mM}$ Hepes buffer. After an incubation period of $20 \mathrm{~min}$, samples $(25 \mu \mathrm{L})$ were analyzed by $1 \%$ agarose gel electrophoresis using Tris-acetate-EDTA buffer. DNA was visualized after ethidium bromide staining.
Table 2. Particle size and zeta potential $(\zeta)$ of lipoplexes obtained from pro-

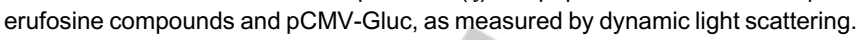
Lipoplexes were prepared at $25^{\circ} \mathrm{C}$, in $5 \%$ glucose, at a N/P ratio of 3 and with 1 molar equivalent of DOPE. Data are the mean of three independent measurements $( \pm \mathrm{SD})$.

\begin{tabular}{|c|c|c|c|}
\hline Entry & Compound & Particle size (nm) & $\zeta(\mathrm{mV})$ \\
\hline 1 & $E_{12}$ & $194 \pm 28$ & $+42 \pm 1$ \\
\hline 2 & $\mathrm{E}_{\mathrm{E} 12}$ & $141 \pm 5$ & $+48 \pm 2$ \\
\hline 3 & $E_{E^{\prime} 12}$ & $149 \pm 15$ & $+39 \pm 2$ \\
\hline 4 & $E_{c_{12}}$ & $117 \pm 15$ & $+40 \pm 1$ \\
\hline 5 & $E_{C^{\prime} 12}$ & $92 \pm 10$ & $+54 \pm 2$ \\
\hline 6 & $E_{E 18: 1}$ & $263 \pm 9$ & $-35 \pm 4$ \\
\hline 7 & $E_{E^{\prime} 18: 1}$ & $597 \pm 19$ & $+45 \pm 2$ \\
\hline 8 & $E_{C 18: 1}$ & $611 \pm 12$ & $+47 \pm 3$ \\
\hline 9 & $E_{C^{\prime} 18: 1}$ & $608 \pm 44$ & $+44 \pm 1$ \\
\hline 10 & $E_{E 2}$ & $133 \pm 10$ & $-31 \pm 2$ \\
\hline 11 & $\mathrm{E}_{\mathrm{E} 6}$ & $144 \pm 31$ & $+47 \pm 6$ \\
\hline 12 & $\mathrm{E}_{\mathrm{E} 8}$ & $110 \pm 4$ & $+36 \pm 1$ \\
\hline 13 & $\mathrm{E}_{\mathrm{E} 10}$ & $122 \pm 11$ & $+41 \pm 3$ \\
\hline 14 & $E_{E 14}$ & $121 \pm 29$ & $+41 \pm 1$ \\
\hline 15 & $E_{E 16}$ & $138 \pm 29$ & $+42 \pm 3$ \\
\hline 16 & $\mathrm{E}_{\mathrm{E} 18}$ & $120 \pm 19$ & $+43 \pm 1$ \\
\hline
\end{tabular}

lipoplexes distinguished as they were negatively charged, which was consistent with significant hydrolysis of the compound in aqueous media. More intriguing was the negative charge measured for lipoplexes prepared from $E_{E_{18: 1}}(-35 \mathrm{mV} \pm 4 \mathrm{mV})$, revealing significant differences in the organization of the lipid molecules and pDNA within the transfection particles (affecting a more precise matching of the ammonium and phosphate species ${ }^{[24]}$, as compared to those obtained with other lipids, especially $\mathrm{E}_{\mathrm{E}^{\prime} 18: 1}$, $E_{\mathrm{C} 18: 1}$ and $E_{C^{\prime} 18: 1}$.

\section{DNA transfection}

The efficacy of the pro-erufosine compounds to deliver a plasmid DNA intracellularly was investigated in the A549 cell line using the reporter gene pCMV-Gluc encoding the Gaussia princeps luciferase, under the control of a CMV promoter. As this luciferase is excreted by cells, transgene expression was directly assessed by standard bioluminescence measurements on cell culture supernatant. Various structural features of the pro-erufosine compounds were examined, in order to identify structure-activity relationships, namely the nature of the biolabile linker (acetal of esters and acetal of carbonates), presence of a substituent on the acetal bridge, and length of the carbon chain introduced on the erufosine phosphate group.

\section{Nature of the biolabile linker}

Considering a fixed-length substituent $\left(\mathrm{C}_{12}\right)$ at the phosphate group of erufosine, the five pro-erufosine compounds $E_{12}, E_{E_{12}}$, $\mathbf{E}_{\mathrm{E}^{\prime} 12}, \mathbf{E}_{\mathrm{C}_{12} \text {, and }} \mathbf{E}_{\mathrm{C}^{\prime} 12}$ were compared in order to investigate the influence of the nature of the biolabile linker on transfection efficiency (Figure 4). No significant transgene expression was 

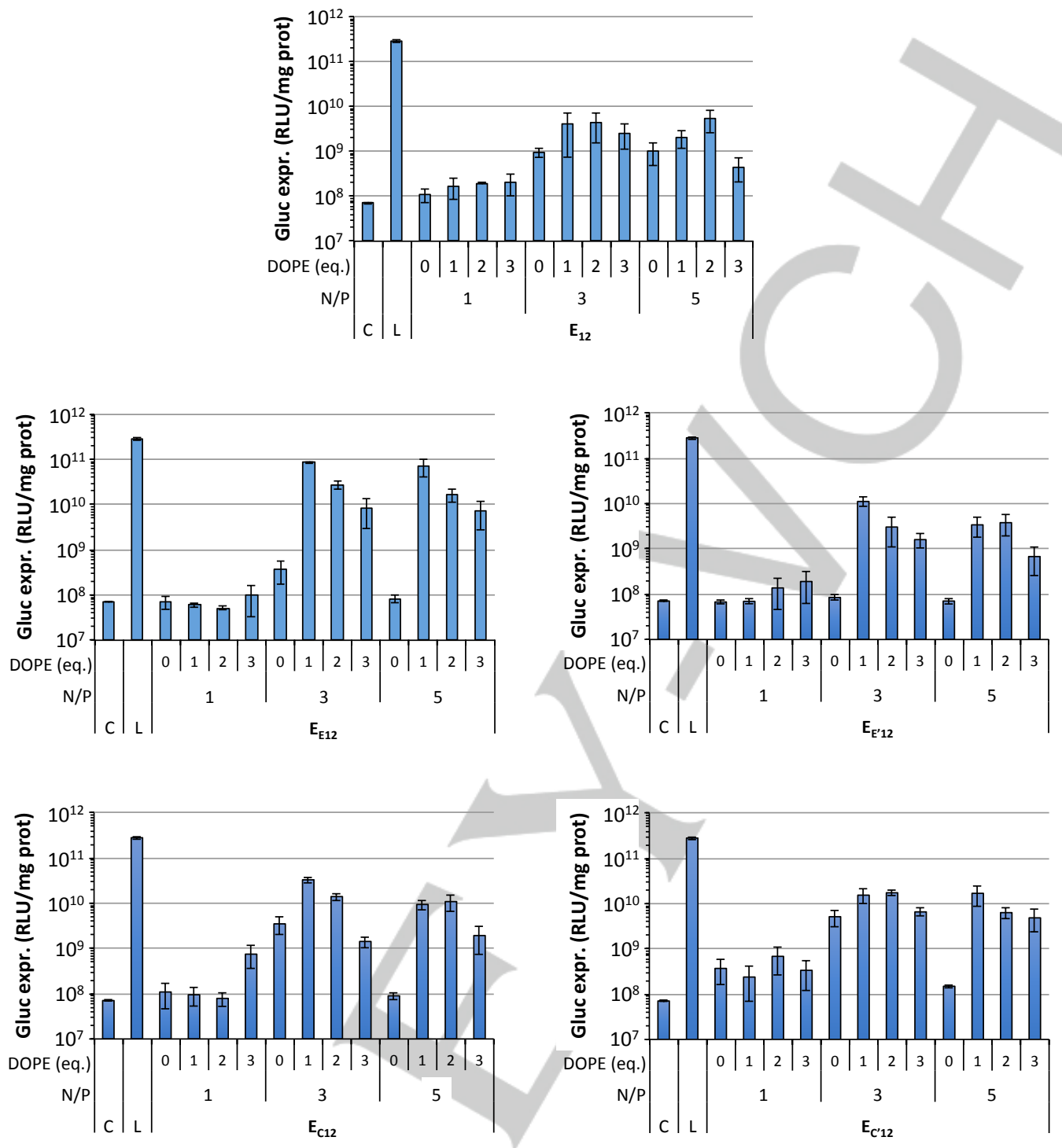

Figure 4. Transfection profile of pro-erufosine compounds as a function of the structure of the biolabile linker installed on the phosphate group. Experiments were carried out on A549 cells, varying the amount of DOPE in the lipid formulations and the charge ratio N/P (DNA: $0.4 \mu \mathrm{g} /$ well), in the presence of $10 \%$ serum. Control (C) refers to basal bioluminescence measured in untreated cells. Lipofectamine ${ }^{\circledR}$-based lipoplexes $(L)$ were prepared under experimental conditions that were optimized according to the supplier's instructions. Data shown are representative of a triplicate determination (mean \pm SD).

generally observed in the absence of DOPE, a fusogenic helper lipid routinely used in transfection experiments. ${ }^{[25]}$ Formulations incorporating up to three molar equivalents of DOPE were systematically evaluated, and one molar equivalent of the fusogenic lipid with respect to the pro-erufosine compound most often led to optimal transfection efficiency. With regards to the chemical nature of the linker installed between the phosphate group of erufosine and the $\mathrm{C}_{12}$ carbon chain (i.e., docecyl or dodecanoyl substituent), acetal ester $\left(\mathrm{E}_{\mathrm{E} 12}\right)$ revealed more efficient to deliver the pCMV-Gluc transgene to cells and was almost matching the results obtained with Lipofectamine ${ }^{\circledR} 2000$, a gold standard gene delivery reagent. Transfection rate was increased by a ca. twentyfold factor, as compared to that of $\mathbf{E}_{12}$ lacking specific biolabile linker. Replacement of the ester by a carbonate (i.e., $\mathbf{E}_{\mathbf{C}_{12}}$ ) resulted in a two- to three-fold decrease in transfection efficiency Besides, introduction of a methyl substituent on the acetal bridge also translated into a loss of transgene expression. The effect was more pronounced in the ester series $\left(8.510^{10} \mathrm{vs}\right.$. $1.110^{10} \mathrm{RLU} / \mathrm{mg}$ protein for $\mathrm{E}_{\mathrm{E} 12}$ and $\mathrm{E}_{\mathrm{E}^{\prime} 12}$, resp.) than in the carbonate series $\left(3.310^{10}\right.$ vs. $1.510^{10} \mathrm{RLU} / \mathrm{mg}$ protein for $\mathbf{E}_{\mathrm{C} 12}$ and $\mathbf{E}_{\mathbf{C}^{\prime} 12}$, resp.). Thus, it was deduced that acceleration of proerufosine hydrolysis was not in favor of a higher transfection rate. This might indicate either that some early decondensation of plasmid in the extracellular milieu decreased cell uptake or that intracellular plasmid decondensation was not achieved in a timely manner, possibly resulting in enhanced DNA degradation by nucleases before reaching the nucleus for processing. 
Considering the compound series displaying an unsaturated $\mathrm{C}_{18: 1}$ pendant arm (i.e., $\mathrm{E}_{\mathrm{E} 18: 1}, \mathrm{E}_{\mathrm{E}^{\prime} 18: 1}, \mathrm{E}_{\mathrm{C}_{18: 1} \text {, and }} \mathrm{E}_{\mathrm{C}^{\prime} 18: 1}$ ), results were slightly different (Figure S1). Whereas optimum transfection rate required the use of one molar equivalent of DOPE or more

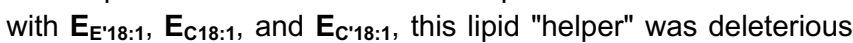
with $E_{E 18: 1}$, decreasing transfection rate by ca. an order of magnitude. With respect to the nature of the biolabile linker, introduction of a methyl substituent on the acetal bridge in the ester series slightly improved transfection efficiency $\left(\mathbf{E}_{\mathrm{E} 18: 1} \mathrm{vs}\right.$. $E_{E^{\prime} 18: 1}$, whereas opposite effect was observed in the carbonate series $\left(E_{C_{18: 1}} v s\right.$. $\left.E_{C^{\prime} 18: 1}\right)$. Together with the results obtained in the $\mathrm{C}_{12}$ series, this highlighted that transfection rate did depend both on the structure of the biolabile linker and on that of the pendant alkyl chain. One hypothesis is that conformation and orientation of the polar head of the molecules facing the aqueous milieu depend on intrinsic structural parameters of the lipid (structure of the pendant hydrophobic arm, nature of the linker, steric hindrance at the acetal bridge...), with direct implications on lipase activity with cascading effects (modification of the hydrolysis rate of the compounds, of pDNA decondensation rate under the threat of nucleases, and ultimately of transfection efficiency).

Lipoplexes of large size are frequently reported to be more effective to promote in vitro transgene expression than smaller ones due to sedimentation and facilitated size-dependent cellular uptake via a switch from a clathrin-dependent to a caveolaemediated cell entry pathway. ${ }^{[26]}$ That was not the case in this study

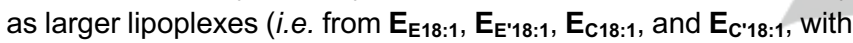
size ranging from 263 to $608 \mathrm{~nm}$ ) revealed less efficient than

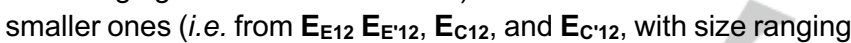
from 92 to $149 \mathrm{~nm}$ ). Similar results for cationic lipids such as SAINTs ${ }^{[27]}$ or COPA ${ }^{[28]}$ have been reported previously. In our study, that probably revealed that due the structure of the proerufosine they were made of, and although internalized by cells to a lesser extent, the smaller lipoplexes were more timely processed in the intracellular compartment.

\section{Influence of the carbon chain length}

Selecting the acetal ester backbone for further structural optimization, systematic variation of the length of the alkyl chain tethered to the biolabile acetal moiety, from 2 to 18 carbon atoms, was realized for investigating its influence on gene delivery properties (Figure 5). Transfection rate clearly depended on alkyl chain length, high transgene expression being obtained provided the alkyl chain contained more than 2 and less than 18 carbon atoms. Results distributed in a quasi-bell-shaped curve, with maximum efficiency attained with the dodecanoyl chain $\left(\mathbf{E}_{\mathbf{E} 12}\right)$. Compound with the shorter chain $\left(\mathrm{E}_{\mathrm{E} 2}\right)$ failed to mediate high transgene expression, maybe in relation to the lack of stability of the compound already aforementioned. At the opposite, degraded transfection rate was observed for compounds with alkyl chains beyond $\mathrm{C}_{16}\left(\mathrm{E}_{\mathrm{E} 18}\right)$, which was yet exacerbated by the presence of an unsaturation in the chain $\left(\mathrm{E}_{\mathrm{E} 18: 1}\right)$. Similar results were obtained in the 16HBE cell line (Figure S2). In this case, degradation of the transfection rate with $\mathrm{E}_{\mathrm{E} 2}$ and $\mathrm{E}_{\mathrm{E} 18: 1}$ was even more marked, which confirmed the deleterious effect of the introduction of a short or unsaturated chain on the carrier backbone.

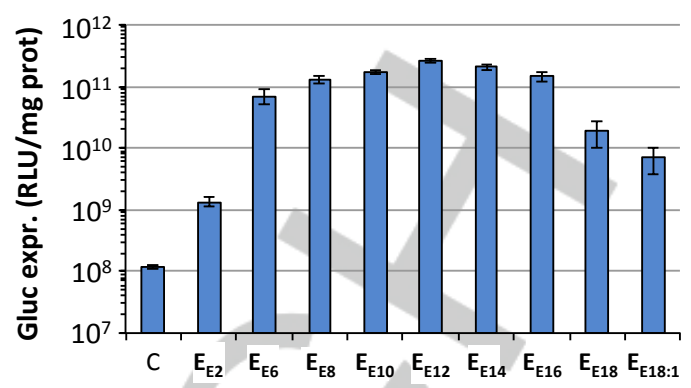

Figure 5. Transfection profile of pro-erufosine $\mathbf{E}_{\mathrm{En}}$ compounds as a function of the length of the alkyl chain tethered to the phosphate group. Experiments were carried out on A549 cells, in the presence of $10 \%$ serum. Lipoplexes were formulated with DOPE (1 eq.) at N/P 3 (DNA: $0.4 \mu \mathrm{g} /$ well). Control (C) refers to basal bioluminescence measured in untreated cells. Data shown are representative of a triplicate determination (mean $\pm S D$ ).

\section{DNA dose and N/P ratio}

As an important parameter governing transgene expression, we then investigated the influence of the pDNA dose deposited onto the cultured cells. A549 cells were treated with increasing amounts of pCMV-Gluc (from 0.1 to $0.4 \mu \mathrm{g} /$ well) formulated into lipoplexes $\left(E_{E 12} / D O P E 1 / 1\right)$ with gradual increase of the N/P ratio (1 to 4). As a general trend and as might be expected, the higher the DNA dose, the higher the transfection rate (Figure 6). However, when increasing the pDNA dose, optimum transfection efficiency was attained at lower N/P ratio. Indeed, at the lower pDNA dose $(0.1 \mu \mathrm{g} /$ well $)$, transfection rate did not yet reach a maximum with N/P increasing up to 4 . At $0.2 \mu \mathrm{g}$ DNA/well, maximum transfection efficiency was attained at N/P ratio of 3-4, whereas it was observed at N/P of $2.75-3$ at $0.3 \mu \mathrm{g} / \mathrm{well}$ and at $\mathrm{N} / \mathrm{P}$ of $2.5-2.75$ at $0.4 \mu \mathrm{g} /$ well. This shift of charge ratio for optimal transfection may be consistently explained by intrinsic cytotoxicity of the DNA carrier (vide infra).

\section{Serum compatibility}

A serious limitation of the cationic lipid-mediated gene delivery is that transfection efficiency is drastically decreased in the presence of serum proteins. This likely results from the formation of the so-called "biocorona" that anionic proteins and other serum components (fatty acids, heparin...) form around the cationic transfection particles, provoking their destabilization and/or stifling their cell uptake and endosome escape. Although some formulations remain efficient at the level of serum content typically used in cell culture $(\leq 10 \%)$, the effect of higher serum levels has been scarcely investigated in prior studies. ${ }^{[29]}$ To gain an insight into the effect of serum on the intracellular delivery of pDNA by erufosine prodrugs, $\mathrm{E}_{\mathrm{E} 12} / \mathrm{DOPE} / \mathrm{pCMV}$-Gluc lipoplexes (1 equiv. DOPE, N/P 3) were incubated with cells in the presence of an increasing concentration of serum, from 10 to $75 \%$ (Figure 7 ). Considering the lower DNA dose $(0.2 \mu \mathrm{g} /$ well), transfection rate was decreased by ca. two orders of magnitude as serum content increased from 10 to $25 \%$, and in $50 \%$ serum (that roughly corresponds to concentration in blood), no transgene expression was detected. When a higher DNA dose $(0.4 \mu \mathrm{g} / \mathrm{well})$ was deposited onto the cells, 


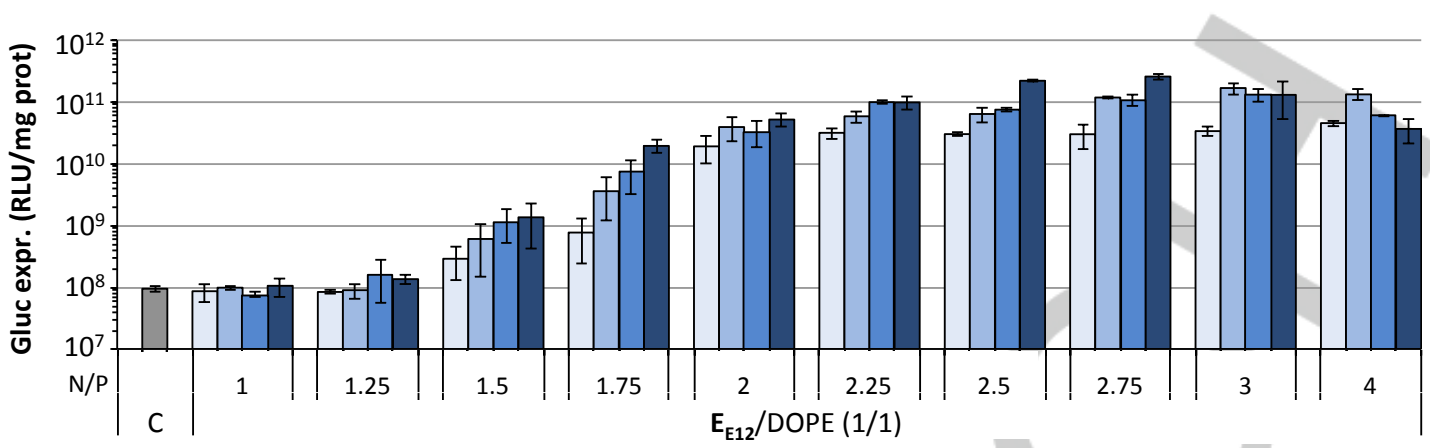

Figure 6. Rate of transfection mediated by pro-erufosine $\mathrm{E}_{\mathrm{E} 12}$ at various charge ratios (N/P varying from 1 to 4$)$, with increasing dose of $\mathrm{pCMV}$-Gluc (0.1, $0.2,0.3$, and $0.4 \mu \mathrm{g} /$ well, from light blue to dark blue, resp.). Experiments were carried out on A549 cells, in the presence of serum (10\%). Lipoplexes were formulated with $\mathrm{DOPE}$ (1 eq.) and control (C) refers to basal bioluminescence measured in untreated cells. Data shown are representative of a triplicate determination (mean \pm SD).

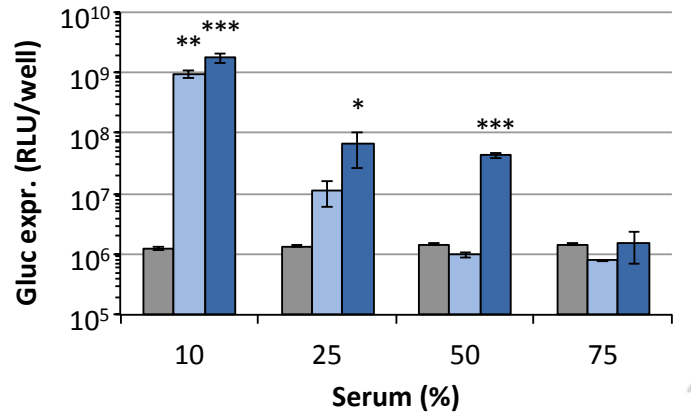

Figure 7. Transfection efficiency as a function of serum content for $\mathrm{E}_{\mathrm{E} 12} / \mathrm{DOPE} / \mathrm{pCMV}-$ Gluc. Lipoplexes were prepared with DOPE (1 equiv.) at N/P 3. Experiments were carried out on A549 cells (6.000 cells/well) and cell supernatant (containing $10 \%$ serum) was replaced with culture medium complemented with $10,25,50$, and $75 \%$ serum just before adding the lipoplexes $(0.2$ and $0.4 \mu \mathrm{g}$ of plasmid per well; light blue and dark blue bars, resp.). Control (grey bars) refers to basal bioluminescence measured in untreated cells. Data shown are representative of a triplicate determination (mean $\pm \mathrm{SD}$ ). Statistically significant differences when compared to untreated cells are indicated: ${ }^{* *} p<0.001,{ }^{* *} p<0.01$, or ${ }^{*} p<0.05$.

deleterious effect of serum was counteracted and significant luciferase production still was measured in $50 \%$ serum.

\section{Intrinsic antitumor activity}

Pro-erufosine compounds have been designed so they may be hydrolyzed in situ under a pH or enzymatic stimulus into erufosine, a compound with intrinsic antitumor activity. In order to characterize the antineoplastic effect of the pro-erufosine compounds, we investigated their physical properties, hemolytic activity, intrinsic cytotoxicity, and combined antitumor activity when used as a carrier for intracellular delivery of a plasmid DNA encoding a proapoptotic protein.

\section{Self-assembly properties of the erufosine prodrugs}

Alkylphospholipids are membrane-active compounds that can disrupt phospholipid bilayers. They can thus interfere with biological membranes delimitating the cellular and intracellular compartments which makes them key players in various membrane signaling pathways involved in carcinogenesis. ${ }^{[1 c]}$ In the absence of serum, the lytic concentration for different APLs has been shown to reflect their critical micellar concentration (CMC) which are in the low $\mu \mathrm{M}$ range. ${ }^{[30]}$ We thus determined the $\mathrm{CMC}$ for erufosine and for the pro-erufosine compounds using the fluorescent probe technique that has been extensively applied to study surfactant micellization. Noteworthy, due to tethering of an "additional" hydrophobic moiety to the erufosine scaffold, proerufosine compounds display a lower hydrophilic-lipophilic balance (HLB) than their parent compound and most likely preferentially form lamellar structures in aqueous environment. Consequently, the term critical aggregation concentration (CAC) is suggested in place of $\mathrm{CMC}^{[31]}$ In this study, pyrene was selected as the hydrophobic fluorescent dye. Fluorescence of pyrene is sensitive to the polarity of the solubilizing medium and the dye exhibits different fluorescence behaviors in hydrophilic and lipophilic environments. Measurements were performed in water and data obtained for erufosine and its prodrugs are collected in Table 3. The CAC value measured for erufosine was

Table 3. Critical aggregation concentration of erufosine and its prodrugs as measured with pyrene by the fluorescent probe technique.

\begin{tabular}{cccccc}
\hline Entry & Compound & $\mathrm{CAC}(\mu \mathrm{M})$ & Entry & Compound & $\mathrm{CAC}(\mu \mathrm{M})$ \\
\hline 1 & $\mathrm{E}$ & $1.6 \pm 0.5$ & 10 & $\mathrm{E}_{12}$ & $0.7 \pm 0.3$ \\
2 & $\mathrm{E}_{\mathrm{E} 2}$ & $7.7 \pm 2.1$ & 11 & $\mathrm{E}_{\mathrm{E} 12}$ & $0.6 \pm 0.2$ \\
3 & $\mathrm{E}_{\mathrm{E} 6}$ & $1.1 \pm 0.7$ & 12 & $\mathrm{E}_{\mathrm{E}^{\prime} 12}$ & $1.1 \pm 0.7$ \\
4 & $\mathrm{E}_{\mathrm{E} 8}$ & $1.0 \pm 0.3$ & 13 & $\mathrm{E}_{\mathrm{C} 12}$ & $1.1 \pm 0.2$ \\
5 & $\mathrm{E}_{\mathrm{E} 10}$ & $0.8 \pm 0.5$ & 14 & $\mathrm{E}_{\mathrm{C}^{\prime} 12}$ & $0.9 \pm 0.2$ \\
6 & $\mathrm{E}_{\mathrm{E} 12}$ & $0.6 \pm 0.2$ & 15 & $\mathrm{E}_{\mathrm{E}_{18: 1}}$ & $0.9 \pm 0.6$ \\
7 & $\mathrm{E}_{\mathrm{E} 14}$ & $1.2 \pm 0.3$ & 16 & $\mathrm{E}_{\mathrm{E}^{\prime} 18: 1}$ & $1.0 \pm 0.6$ \\
8 & $\mathrm{E}_{\mathrm{E} 16}$ & $1.3 \pm 0.4$ & 17 & $\mathrm{E}_{\mathrm{C}_{18: 1}}$ & $0.8 \pm 0.4$ \\
9 & $\mathrm{E}_{\mathrm{E} 18}$ & $1.4 \pm 0.7$ & 18 & $\mathrm{E}_{\mathrm{C}^{\prime} 18: 1}$ & $0.6 \pm 0.2$ \\
\hline
\end{tabular}


$1.56 \pm 0.47 \mu \mathrm{M}$ and no earlier data was found in the literature. Interestingly, CMC values below $10 \mathrm{nM}$ have been suggested for erucylphosphocholine (ErPC), an erufosine homolog compound. ${ }^{[32]}$ It cannot be excluded that replacement of the ethylene group with a propylene one between the phosphate and ammonium moieties can have an effect on the solvation state of the zwitterionic head group of the lipid and, consequently, on the CMC of the compound. However, if such an effect has been already reported, e.g., for hexadecylphosphocholine (miltefosine) and hexadecylphosphohomocholine (with CMC values of 13 and $20 \mu \mathrm{M}$, resp.), ${ }^{[33]}$ it was of lower magnitude. As expected, transformation of erufosine into pro-erufosine compounds through the replacement of the phosphate negative charge by a hydrophobic substituent translated into a decrease in the CAC values. This was not the case however for $\mathrm{E}_{\mathrm{E} 2}$. The reason for this is unclear. It might be proposed that the introduction of an acetoxymethyl substituent (a short polyoxygenated group that can establish hydrogen bonds with water molecules) on the phosphate group of erufosine did not much change the global hydrophobicity of the molecule while better complexation of the trimethylammonium moiety by water molecules (as compared to zwitterion) did enhance hydrophilicity of the polar head group, thus improving aqueous solubility of the compound. CAC slightly decreased with alkyl chain elongation up to $C_{12}$, then a reverse effect was observed up to $\mathrm{C}_{18}$ (Figure S3). This however must be considered with caution, as standard deviations in CAC measurements were significant. For the same reason, no trend could be detected with respect to the structure of the biolabile spacer (i.e., ester vs. carbonate and non-substituted vs. substituted acetal), or to the introduction of an unsaturation in the $\mathrm{C}_{18}$ chain. Differences were small and getting a deeper understanding of the structure-property relationships would require a more precise determination of the CAC values.

\section{Hemolytic activity}

Hemolytic activity is associated with most of the antitumor APLs described to date, so these compounds are not compatible with intravenous administration. ${ }^{[30 a]}$ When APLs are used in liposomal formulations (e.g., co-formulated with cholesterol and 1,2dipalmitoyl-sn-glycero-phosphoglycerol), lysis of red blood cells can be partly prevented. ${ }^{[34]}$ This however is accompanied by a significant reduction in the antitumor activity of the compound, as previously shown in vitro. ${ }^{[35]}$ In serum-free conditions, the lytic concentration for various APLs and related compounds generally corresponds well to their CMC. ${ }^{[30]}$ Decreasing the CMC of APLs through their reversible transformation into more hydrophobic derivatives should thus result in increasing their biocompatibility. To investigate this point, the hemolytic activity of erufosine and pro-erufosine compounds was determined using an erythrocyte leakage assay. Sheep red blood cells (RBC) were treated with increasing amounts of aqueous dispersion of the compounds at $37^{\circ} \mathrm{C}$ and hemolysis (hemoglobin leakage) was monitored spectrophotometrically. First, we investigated the hemolytic effect of erufosine over an incubation period of $1 \mathrm{~h}$. As expected, damage to the RBC increased with the APL concentration. The concentration provoking $50 \%$ hemolysis $\left(\mathrm{HC}_{50}\right)$ was around $130 \mu \mathrm{M}$ and $84.9 \pm 4.6 \%$ hemolysis was achieved at $200 \mu \mathrm{M}\left(\mathrm{HA}_{200}\right)$ (Table 4 and Figure S4). Under the same incubation conditions, hemolytic
Table 4. Hemolytic activity of erufosine and pro-erufosine compounds upon incubation with sheep RBC for 1 and $24 \mathrm{~h}$ at $37^{\circ} \mathrm{C}$.

\begin{tabular}{ccccccc}
\hline \multirow{2}{*}{ Entry } & \multirow{2}{*}{ Compound } & \multicolumn{2}{c}{$1 \mathrm{~h}$} & \multicolumn{2}{c}{$24 \mathrm{~h}$} \\
\cline { 7 - 7 } \cline { 6 - 7 } & & $\mathrm{HC}_{50}(\mu \mathrm{M})$ & $\mathrm{HA}_{200}(\%)$ & & $\mathrm{HC}_{50}(\mu \mathrm{M})$ & $\mathrm{HA}_{200}(\%)$ \\
\hline 1 & $\mathrm{E}$ & 130 & $84.9 \pm 4.6$ & & - & - \\
2 & $\mathrm{E}_{\mathrm{E} 6}$ & - & $25.0 \pm 0.3$ & & 140 & $85.2 \pm 6.2$ \\
3 & $\mathrm{E}_{12}$ & - & $0.5 \pm 0.4$ & & - & $12.0 \pm 1.9$ \\
4 & $\mathrm{E}_{\mathrm{E} 12}$ & - & $<0.5$ & & - & $18.6 \pm 1.5$ \\
5 & $\mathrm{E}_{\mathrm{E}^{\prime} 12}$ & - & $<0.5$ & & - & $8.7 \pm 1.1$ \\
6 & $\mathrm{E}_{\mathrm{C} 12}$ & - & $<0.5$ & & - & $9.6 \pm 2.3$ \\
7 & $\mathrm{E}_{\mathrm{C}^{\prime} 12}$ & - & $0.7 \pm 0.2$ & - & $7.3 \pm 0.8$ \\
8 & $\mathrm{E}_{\mathrm{E}_{18}}$ & - & $<0.5$ & - & $11.3 \pm 4.0$ \\
9 & $\mathrm{E}_{\mathrm{E}_{18: 1}}$ & - & $1.0 \pm 0.3$ & - & $1.2 \pm 0.7$ \\
\hline
\end{tabular}

[a] Concentration of compound inducing $50 \%$ hemolysis. [b] Percentage of hemolysis provoked by the compound at the higher concentration tested (200 $\mu \mathrm{mol})$.

effect of most of the pro-erufosine compounds was below a measurable amount (<1\%) except for $\mathrm{E}_{\mathrm{E} 6}\left(\mathrm{HA}_{200}: 25.0 \pm 0.3\right)$. In order to better characterize the pro-erufosine compounds, the hemolytic effect of two pro-erufosine compounds was measured over extended periods of time (Figure 8 and Figure S5-S6). As might be expected, hemolysis increased with time and reached significant values after 18-24 h. Consequently, a 24-h incubation time was chosen in the following evaluations so as to discriminate against the pro-APLs (Figure S7). Even under these tough incubation conditions, the pro-erufosine compounds revealed only slightly harmful to $\mathrm{RBC}$, with $\mathrm{HA}_{200}$ values below $20 \%$ (Table 4). Again, $\mathbf{E}_{\mathbf{E} 6}$ stood as an exception displaying a $\mathrm{HA}_{200}$ value of $85.2 \pm 6.2 \%$, whereas $\mathrm{HC}_{50}$ was around $140 \mu \mathrm{M}$. At the opposite, no general trend was observed with regards to the structure of the biolabile linker, and lower hydrolytic stability did not systematically translate into higher hemolytic effect.

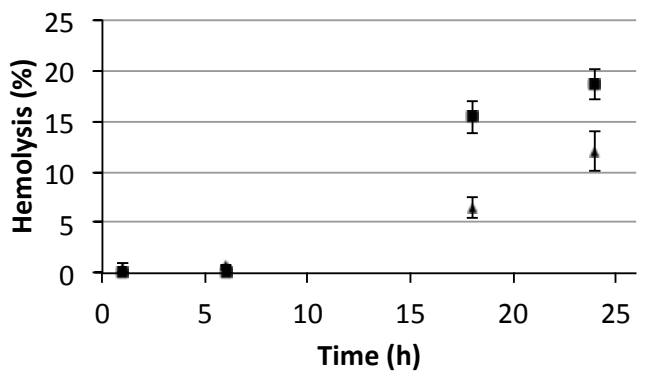

Figure 8. Time course of hemolytic activity of pro-erufosine EE12 ( $\square$ ) and E12 $(\boldsymbol{\Delta})$. Sheep RBC were incubated at $37^{\circ} \mathrm{C}$ with $200 \mu \mathrm{M}$ of the compounds. 
Considering these data, it was concluded that the transformation of erufosine into prodrugs drastically reduces the hemolytic activity, which makes the pro-erufosine compounds highly compatible with intravenous administration.

\section{Cytotoxic effect}

The intrinsic cytotoxicity of APLs is not strictly related to their ability to permeabilize membranes and lyse cells. It is widely assumed that, at pharmacologically relevant concentration, APLs insert into the cell membrane, provoking a biophysical disturbance through altered cholesterol homeostasis, and perturbing various signal transduction pathways. ${ }^{[1 \mathrm{c}]}$ In order to estimate the antiproliferative potency of the pro-erufosine compounds, a dose-response study was conducted in three human pulmonary cell lines: A549 (alveolar carcinoma epithelial cells), H292 (carcinoma mucoepidermoid cells), and 16HBE (bronchial epithelial cells). Thirteen pro-erufosine compounds were tested in parallel with parent erufosine. Cells were exposed for $24 \mathrm{~h}$ to concentration of lipids between $500 \mathrm{nM}$ and $1 \mathrm{mM}$, and cell survival was determined using the MTT assay. ${ }^{[36]}$ For the three cell lines, a concentration dependent decrease in cell viability was seen in response to erufosine and pro-erufosine compounds (Figure S8-S10). Interpolated from the experimental concentration-effect curves, the $\mathrm{IC}_{50}$ values (concentration that inhibited the cell growth by $50 \%$ ) reflecting the cytotoxicity of the compounds are presented in Table 5. The three cell lines showed varying sensitivities to the compounds. The $\mathrm{IC}_{50}$ values ranged from 57 to $199 \mu \mathrm{M}$ for A549 cells, from 43 to $174 \mu \mathrm{M}$ for $\mathrm{H} 292$ cells, and from 19 to $257 \mu \mathrm{M}$ for non-cancerous $16 \mathrm{HBE}$ cells. Cytotoxicity of the erufosine prodrugs did not parallel their hydrolytic stability as determined by ${ }^{31} \mathrm{P}-\mathrm{NMR}$ measurements in an "enzyme-free" model aqueous medium (vide supra). This likely originates from the in situ enzymatic hydrolysis of the pro-APLs compounds in the complemented culture medium which competes with pure $\mathrm{pH}$-controlled chemical hydrolysis. Depending on the pro-APL, its structure and the nature of the substituent installed on the phosphate group, the compound may or not be a substrate for some specific lipases and, thus, may or may not be metabolized into parent cytotoxic erufosine. However, all the proerufosine compounds displayed marked cytotoxicity that roughly compared to that of erufosine (i.e., with $\mathrm{IC}_{50}$ in the low $\mu \mathrm{M}$ range), revealing that they were productively metabolized into erufosine, though not at the same rate. It is noteworthy that $\mathrm{E}_{\mathrm{E} 2}$ that distinguished by lower chemical stability as compared to the other pro-erufosine compounds (vide supra) was among the less cytotoxic prodrugs in the series, with $I \mathrm{I}_{50}$ values that were three to ten times higher than that of erufosine, depending on the cell line. Considering the prodrugs in the ester series $\left(E_{E n}\right)$ and except for $\mathrm{E}_{\mathrm{E} 2}$ (vide supra), a general trend was that the $\mathrm{IC}_{50}$ value steadily increased with the length of the pendant arm tethered to erufosine (i.e., with $\mathrm{n}$ ), up to $\mathrm{C}_{16}$. A longer chain (i.e., $\mathrm{C}_{18}$ ) tended to decrease the $I_{50}$ value, and unsaturation in the $C_{18}$ chain further enhanced this fall. These effects were marked in the A549 cell line (Figure S11), and the same trends were identified in the $\mathrm{H} 292$ and $16 \mathrm{HBE}$ cell lines, although all the compounds in these series have not been systematically assayed. Finally, with regard to the aggregation properties of the compounds, no relationship could
Table 5. Antitumor activity ( $\mathrm{IC}_{50}$ ) of erufosine and pro-erufosine compounds in various cell lines exposed for $24 \mathrm{~h}$ at $37^{\circ} \mathrm{C}$, as measured by MTT dye reduction assay.

\begin{tabular}{|c|c|c|c|c|}
\hline \multirow{2}{*}{ Entry } & \multirow{2}{*}{ Compound } & \multicolumn{3}{|c|}{$\mathrm{IC}_{50}(\mu \mathrm{M})$} \\
\hline & & A549 & H292 & $16 \mathrm{HBE}$ \\
\hline 1 & $E$ & $57 \pm 8$ & $46 \pm 8$ & $19 \pm 3$ \\
\hline 2 & $E_{E 2}$ & $171 \pm 44$ & $174 \pm 39$ & $208 \pm 66$ \\
\hline 3 & $\mathrm{E}_{\mathrm{E} 6}$ & $60 \pm 8$ & $43 \pm 7$ & $58 \pm 14$ \\
\hline 4 & $\mathrm{E}_{\mathrm{E} 8}$ & $88 \pm 10$ & - & - \\
\hline 5 & $E_{E 10}$ & $136 \pm 40$ & - & - \\
\hline 6 & $E_{12}$ & $81 \pm 7$ & $124 \pm 11$ & $225 \pm 31$ \\
\hline 7 & $\mathrm{E}_{\mathrm{E} 12}$ & $151 \pm 42$ & $125 \pm 26$ & $144 \pm 66$ \\
\hline 8 & $E_{E^{\prime} 12}$ & $192 \pm 44$ & $73 \pm 15$ & $63 \pm 7$ \\
\hline 9 & $\mathrm{E}_{\mathrm{C} 12}$ & $161 \pm 21$ & $167 \pm 56$ & $252 \pm 112$ \\
\hline 10 & $E_{C^{\prime} 12}$ & $179 \pm 63$ & $161 \pm 25$ & $257 \pm 81$ \\
\hline 11 & $\mathrm{E}_{\mathrm{E} 14}$ & $193 \pm 59$ & - & - \\
\hline 12 & $\mathrm{E}_{\mathrm{E} 16}$ & $199 \pm 30$ & - & - \\
\hline 13 & $\mathrm{E}_{\mathrm{E} 18}$ & $170 \pm 72$ & $141 \pm 49$ & $165 \pm 63$ \\
\hline 14 & $E_{E 18: 1}$ & $97 \pm 35$ & $61 \pm 20$ & - \\
\hline
\end{tabular}

be established between $\mathrm{CAC}$ and $\mathrm{IC}_{50}$ values, thus confirming that the cytotoxic effect of erufosine and pro-erufosine compounds was not achieved through their membrane disrupting properties.

\section{Combined antitumor activity of TRAIL and erufosine prodrugs}

The use of combination therapy for cancer treatment is well established. ${ }^{[37]}$ Indeed, single-agent therapy aims to suspend one signaling pathway and cancer cells can thrive through the initial oncogenic route and activate another parallel signaling pathway. ${ }^{[38]}$ Multi-agent therapy can simultaneously modulate several signaling pathways in diseased cells, maximizing the therapeutic effect and, possibly, overcoming resistance mechanisms. Whereas chemotherapy drugs are normally associated with severe side-effects, administration of a combination of agents hitting various targets in different pathways and displaying different toxicity profiles can improve the therapeutic index, either in the form of better efficacy, or in the form of comparable efficacy and reduced toxicity. In recent years, combination anticancer therapy between nucleic acids and smallmolecule drugs has been recommended for cancer treatment because of such advantages and because it can serve to overcome genetic heterogeneity and existence of complicated signaling pathways. ${ }^{[39]}$ Besides, compared with coordinate treatment with two drugs in separated carriers, the co-delivery of two agents in one single carrier may allow resolving the 
complexity of variation in pharmacokinetics and ensures the colocalization of the two agents to maximize the additive or synergistic effect, thereby reducing the amount of each drug and promoting the efficacy of the combination therapy. ${ }^{[40]}$ Our hypothesis herein was that the combination of pro-APLs and pDNA encoding a pro-apoptotic protein would diminish tumor cell survival and show at least an additive antineoplastic effect.

Therefore, in order to investigate antitumor effect of the proerufosine compounds as both gene delivery reagents and prodrugs of antiproliferative erufosine, a plasmid DNA encoding the tumor necrosis factor-related apoptosis-inducing ligand (TRAIL, also called Apo2L or TNFSF10) was selected. As a member of the tumor necrosis factor (TNF) superfamily, TRAIL can induce apoptosis in malignant tumors while sparing normal cells. $^{[41]}$ In humans, TRAIL activates extrinsic apoptotic pathway after binding TRAIL death receptors (DRs), TRAIL-R1 (DR4, TNFRSF10A) and TRAIL-R2 (DR5, TNFRSF10B), and TRAIL decoy receptors that do not possess functional death domain, TRAIL-R3 (DcR1, TNFRSF10C) and TRAIL-R4 (DcR2, TNFRSF10D). Like most TNF superfamily members, TRAIL is a homotrimeric, type II transmembrane protein. It can thus simultaneously recruit several receptors. If the recruited receptors are all death receptors (i.e., DR4 or DR5), a death-inducing signaling complex (DISC) is formed that can strongly activate various caspases inducing apoptosis. At the opposite, recruitment of inhibitor receptors (i.e., DcR1 or DcR2) leads to a DISC that cannot or only weakly activate caspases and therefore impairs TRAIL-induced cell death. ${ }^{[42]}$ Nevertheless, the situation may be further complicated by the cell-type dependency of the apoptotic response, itself influenced by the effect on ligand binding mode of factors such as the level of TRAIL oligomerization or glycosylation. ${ }^{[43]}$

\section{Characterization of TRAIL receptor expression and activity in the different cell lines}

Characterization of the expression and activity of the TRAIL receptors in the different cell lines was a prerequisite to validate the cell models suitable for evaluation of combined antitumor activity of TRAIL and erufosine prodrugs. Expression of the TRAIL receptors was assessed by flow cytometry (Figure 9). Death receptors TRAIL-R1 and TRAIL-R2 were expressed in the three cell lines in similar amounts, except for TRAIL-R1 which expression was significantly higher in A549 cells. TRAIL-R3 was expressed only in $\mathrm{H} 292$ and 16HBE cells while TRAIL-R4 was not expressed in any cell line. The sensitivity of the three cell lines to TRAIL was then checked using SuperKillerTRAIL ${ }^{\circledR}$ (SPK), a hexameric TRAIL recombinant protein providing significantly enhanced apoptosis. ${ }^{[44]}$ Cells were incubated with SPK for $24 \mathrm{~h}$ and cell viability was subsequently measured (Figure S12). SPK induced apoptosis of $\mathrm{H} 292$ and $16 \mathrm{HBE}$ cells in a dose-dependent manner, with $\mathrm{EC}_{50}$ of $0.49 \pm 0.18$ and $0.68 \pm 0.39 \mathrm{nM}$, respectively (i.e., $12.7 \pm 4.7$ and $17.6 \pm 10.2 \mathrm{ng} / \mathrm{mL}$ ). Noteworthy, the $\mathrm{EC}_{50}$ value for SPK in $\mathrm{H} 292$ cancer cells was significantly lower than that reported for TRAIL $(25 \pm 5 \mathrm{ng} / \mathrm{mL})^{[45]}$ which is consistent with the hexameric structure of SPK. Sensitivity of the non-tumor 16HBE cells to TRAIL was unexpected and revealed that recombinant SPK may not reflect properly all the properties of monomeric TRAIL. By contrast, only low induction of apoptosis was observed in A549 cells, since cell viability still was higher than $70 \%$ at the SPK dose of $200 \mathrm{ng} / \mathrm{mL}$. Once again these data are consistent with those in the literature $\left(\mathrm{IC}_{50}>1500 \mathrm{ng} / \mathrm{mL}\right)$. ${ }^{[45]}$ Taken together, these results suggest that induction of apoptosis in the three cell models using a plasmid DNA encoding TRAIL should be feasible, though A549 cells that expressed the higher level of TRAIL-R1 appeared unexpectedly less sensitive to SPK than $\mathrm{H} 292$ and $16 \mathrm{HBE}$ cells.

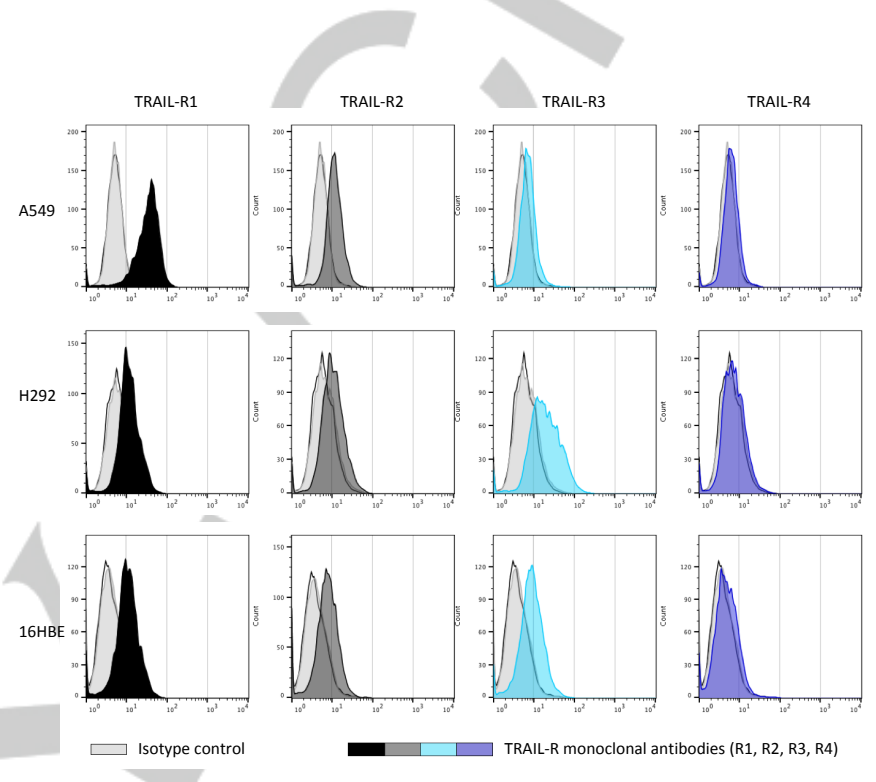

Figure 9. Expression of the TRAIL receptors in the three cell lines as monitored by flow cytometry. The fluorescence histograms were obtained using PEconjugated antibodies.

\section{Combined cytotoxic activity}

Pro-erufosine $\mathrm{E}_{\mathrm{E} 12}$ was selected as the best pro-erufosine candidate for the following experiments. The three cell lines were treated for $24 \mathrm{~h}$ with lipoplexes prepared with either pCMV-Gluc or pUNO1-hTRAIL, a plasmid DNA encoding TRAIL. The transfection particles were prepared with one equivalent of DOPE at a charge ratio of 3 , corresponding to the previously established optimized conditions (vide supra). The dose of pDNA applied to the cells was varied from 0.1 to $0.4 \mu \mathrm{g}$ DNA per well and incubation was carried out for $24 \mathrm{~h}$. For comparison, Lipofectamine ${ }^{\circledR}$ was assayed in parallel.

Luciferase expression was determined in the three cell lines, and A549 and H292 cells displayed very similar expression profiles (Figure S13). On the other hand, $16 \mathrm{HBE}$ cells revealed a little bit less responsive, since $\mathrm{E}_{\mathrm{E} 12}$-mediated transgene expression was approximately four times weaker in this cell line, while remaining at the higher rate with Lipofectamine ${ }^{\circledR}$. In any case, the transfection rate in the three cell lines was highly significant, suggesting that replacing pCMV-Gluc with pUNO1-hTRAIL should give rise to significant expression of TRAIL.

Cell viability was monitored in the three cell lines treated with pCMV-Gluc and pUNO1-hTRAIL (Figure 10). Control experiments with Lipofectamine ${ }^{\circledR}$ revealed no decrease in cell viability using pUNO1-hTRAIL as compared to pCMV-Gluc. Although this could indicate that no functional TRAIL was produced, it is worth noting 


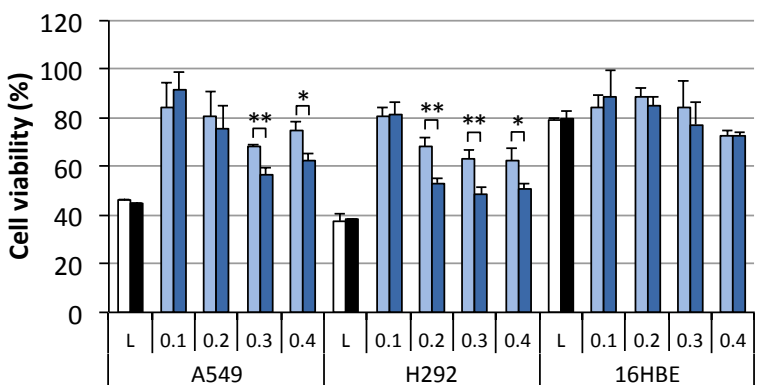

Figure 10. Antiproliferative effect of lipoplexes prepared from $\mathrm{E}_{\mathrm{E} 12}$ or Lipofectamine ${ }^{\circledR} 2000$ (L), and pCMV-Gluc (light blue and white bars, resp.) or pUNO1-hTRAIL (dark blue and black bars, resp.) on three cell lines. Proerufosine-based lipoplexes were formulated with DOPE (1 eq.) at N/P 3, with a pDNA dose varying from 0.1 to $0.4 \mu \mathrm{g} /$ well. Lipofectamine-based lipoplexes $(0.1 \mu \mathrm{g}$ plasmid/well) were prepared according to the optimized experimental conditions provided by the supplier. Cell viability was measured by MTT assay. Data shown are representative of a triplicate determination (mean $\pm S D$ ). Statistically significant differences are indicated: ${ }^{* * *} p<0.001,{ }^{* *} p<0.01$, or ${ }^{*} p<0.05$.

that intrinsic cytotoxicity of this transfection reagent was basically very high both in A549 and $\mathrm{H} 292$ cells (with less than $40-50 \%$ cell survival), and thus could mask some effect of TRAIL. In the nontumor 16HBE cell line, no such intrinsic cytotoxicity of Lipofectamine ${ }^{\circledR}$ could be invoked $(\sim 20 \%)$, but data were consistent with the resistance of non-tumor cells to TRAIL. ${ }^{[46]}$ With regards to the pro-erufosine PDNA delivery reagent $\mathbf{E}_{E_{12}}$, statistically significant enhancement of cytotoxicity was observed with pUNO1-hTRAIL, as compared to PCMV-Gluc, in A549 and $\mathrm{H} 292$ cells, but not in $16 \mathrm{HBE}$ cells. This effect was clearly visible from the intermediate plasmid dose of $0.2 \mathrm{ng} / \mathrm{mL}$ and indicated that the transgene product was indeed functional and did express intrinsic antineoplastic effect in the two tumor cell lines. Resistance of the non-tumor 16HBE cells to TRAIL again was consistent with results in the literature. Finally, the combination of pro-erufosine compound $\mathrm{E}_{\mathrm{E} 12}$ and pUNO1-hTRAIL induced death of A549 and $\mathrm{H} 292$ tumor cells selectively (cell death $>40-50 \%$ ) while preserving normal $16 \mathrm{HBE}$ cells (cell death $<20-25 \%$ ). Extensive work now is required on various testing platforms to determine whether there is synergism between the pro-erufosine compound and pUNO1-hTRAIL or simply additive anticancer effect, and identify optimal dose combination as certain dose ratios of combined drugs can be synergistic, while other ratios may be antagonistic. ${ }^{[47]}$

\section{Conclusion}

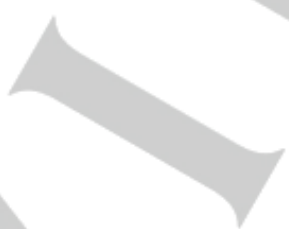

In the present study, we designed and optimized cationic prodrugs of erufosine, and investigated their properties as both gene delivery reagents and antineoplastic drugs. We demonstrated that these pro-erufosine compounds can efficiently deliver plasmid DNA to mammal cells and that those incorporating a $\mathrm{pH}$ - or enzyme-specific cleavage site were invariably more potent -at least by an order of magnitude- than an analog compound lacking such specific cleavage site. These results thus demonstrate the superiority of biolabile lipids bearing transient cationic charge in DNA delivery experiments. We also showed that these gene carriers are further degraded into parent antitumor erufosine and thus express intrinsic antitumor properties but are not associated with any hemolytic effect, as is the case for erufosine. Finally, using a plasmid DNA encoding the pro-apoptotic protein TRAIL, we evidenced selective toxicity towards tumor cells while non-tumor cells were resistant. Together, it appears that the combination approach involving well tolerated erufosine cationic prodrugs and cancer gene therapy holds significant promise and, e.g., might be useful in the management of some drug-resistant tumors.

\section{Experimental Section}

\section{Materials}

Unless otherwise stated, all chemical reagents were purchased from Alfa Aesar (Bischeim, France) and used without purification. When required, solvents were dried just before use as described elsewhere.[488]] Thin layer chromatography (TLC) was performed on precoated plates $(0.25 \mathrm{~mm}$ Silica Gel 60, $\mathrm{F}_{254}$, Merck, Darmstadt, Germany). Products were purified by flash chromatography over silica gel (Silica Gel 60, 40-63 $\mu \mathrm{m}$, Merck, Darmstadt, Germany). NMR spectra were recorded on Bruker $400 \mathrm{MHz}$ Avance III instrument. ${ }^{1} \mathrm{H}-,{ }^{13} \mathrm{C}$-, and ${ }^{31} \mathrm{P}-\mathrm{NMR}$ chemical shifts $\delta$ are reported in ppm relative to their standard reference $\left({ }^{1} \mathrm{H}: \mathrm{CHCl}_{3}\right.$ at $7.27 \mathrm{ppm}$, $\mathrm{CD}_{2} \mathrm{HOD}$ at $3.31 \mathrm{ppm} ;{ }^{13} \mathrm{C}: \mathrm{CDCl}_{3}$ at $77.0 \mathrm{ppm}, \mathrm{CD}_{3} \mathrm{OD}$ at $49.0 \mathrm{ppm} ;{ }_{31} \mathrm{P}$ : $(\mathrm{MeO})_{2} \mathrm{P}(\mathrm{O}) \mathrm{Me}$ at $\left.38.78 \mathrm{ppm}\right)$. IR spectra were recorded on a FT-IR Nicolet 380 spectrometer in the ATR mode and absorption values $v$ are in wave numbers $\left(\mathrm{cm}^{-1}\right)$. Mass Spectra (MS) were recorded on an Agilent Technologies 6520 Accurate Mass QToF instrument, using electrospray ionization (ESI) mode. Mass data are reported in mass units $(\mathrm{m} / \mathrm{z}) .1,2-$ Dioleoyl-sn-glycero-3- phosphoethanolamine (DOPE) was from Avanti Polar Lipids (Alabaster, USA). Lipofectamine ${ }^{\circledR} 2000$ was obtained from Invitrogen (Cergy Pontoise, France). Plasmid pCMV-Gluc (5.7 kbp) and coelenterazine substrate for monitoring Gaussia luciferase activity were from Nanolight Technology (Pinetop, Az, USA). Plasmid pUNO1-hTRAIL (4026 bp) was from InvivoGen (Toulouse, France) and SuperKillerTRAIL ${ }^{\circledR}$ (SPK, 26 kDa) was from Enzo Life Sciences (Villeurbanne, France). PEconjugated anti-TRAIL antibodies used in flow cytometry analysis were from Diaclone (Besançon, France). 3-(4,5-Dimethylthiazol-2-yl)-2,5diphenyl tetrazolium bromide (MTT) was from Sigma-Aldrich (SaintQuentin Fallavier, France). Culture media DMEM, DMEM/F12, RPMI, and supplements were from GIBCO-BRL (Cergy-Pontoise, France). Fetal calf serum (FCS) was from Perbio (Brebières, France). A549 cells (human lung carcinoma; CCL-185), and $\mathrm{NCl}-\mathrm{H} 292$ (H292) cells (human lung mucoepidermoid carcinoma; CRL-1848) were obtained from ATCC-LGC (Molsheim, France). The 16HBE14o- (16HBE) cells were a generous gift from Dr D. Gruenert (California Pacific Medical Center Research Institute, San Francisco, CA, USA). Defibrinated sheep blood was from Eurobio (Les Ulis, France).

Abbreviations: PE, petroleum ether; s, singlet; $d$, doublet; $t$, triplet; $q$, quadruplet; b, broad.

\section{Synthesis}

Erufosine (E). Triethylamine $(1.30 \mathrm{~mL}, 9.27 \mathrm{mmol})$ was added dropwise to phosphorus oxychloride $(288 \mu \mathrm{L}, 3.09 \mathrm{mmol})$ in anhydrous $\mathrm{CH}_{2} \mathrm{Cl}_{2}(10 \mathrm{~mL})$ at $0{ }^{\circ} \mathrm{C}$ under inert atmosphere. Then erucyl alcohol[[49]] $(1.00 \mathrm{~g}$, $3.09 \mathrm{mmol})$ in $\mathrm{CH}_{2} \mathrm{Cl}_{2}(15 \mathrm{~mL})$ was added dropwise over a $90-\mathrm{min}$ period and the reaction mixture was allowed to warm to rt for $30 \mathrm{~min}$, time after 
which all the alcohol had reacted. Temperature was brought back to $0{ }^{\circ} \mathrm{C}$ and 1,3-propanediol $(223 \mu \mathrm{L}, 3.09 \mathrm{mmol})$ in $\mathrm{CH}_{2} \mathrm{Cl}_{2}(15 \mathrm{~mL})$ was added dropwise within $60 \mathrm{~min}$. The reaction mixture was stirred at it for $16 \mathrm{~h}$ before quenching by addition of $10 \% \mathrm{HCl}(10 \mathrm{~mL})$. It was extracted twice with $\mathrm{CH}_{2} \mathrm{Cl}_{2}$, and the organic layer was washed with brine, dried over $\mathrm{MgSO}_{4}$, filtered, and reduced under vacuum. The crude residue was purified by flash chromatography $\left(\mathrm{Et}_{2} \mathrm{O}\right)$ to yield 2-erucyloxy-1,3,2dioxaphosphinane 2-oxide $(0.82 \mathrm{~g}, 60 \%) \cdot R_{\mathrm{f}}: 0.30\left(\mathrm{Et}_{2} \mathrm{O}\right) .{ }^{1} \mathrm{H}-\mathrm{NMR}(400$ $\left.\mathrm{MHz}, \mathrm{CDCl}_{3}\right) \delta 0.88(\mathrm{t}, J=6.6 \mathrm{~Hz}, 3 \mathrm{H}) ; 1.26(\mathrm{~m}, 30 \mathrm{H}) ; 1.61$ and $1.77(2$ $\mathrm{m}, 1 \mathrm{H}) ; 1.72(\mathrm{~m}, 2 \mathrm{H}) ; 2.00(\mathrm{~m}, 4 \mathrm{H}) ; 2.26\left(\mathrm{dtt}, J_{1}=15.3 \mathrm{~Hz}, J_{2}=10.3 \mathrm{~Hz}\right.$, $\left.J_{3}=5.3 \mathrm{~Hz}, 1 \mathrm{H}\right) ; 4.09\left(\mathrm{td}, J_{1}=J_{2}=6.9 \mathrm{~Hz}, 2 \mathrm{H}\right) ; 4.32-4.45(\mathrm{~m}, 4 \mathrm{H}) ; 5.34(\mathrm{~m}$, 2H). ${ }^{13} \mathrm{C}-\mathrm{NMR}\left(100.7 \mathrm{MHz}, \mathrm{CDCl}_{3}\right) \delta 14.3 ; 22.9 ; 25.7 ; 26.4 ; 27.4(2 \mathrm{C})$; $29.4 ; 29.5(3 \mathrm{C}) ; 29.7(2 \mathrm{C}) ; 29.8(4 \mathrm{C}) ; 30.0(2 \mathrm{C}) ; 30.5 ; 32.1 ; 67.8$; 68.6 (2C); 130.1 (2C). ${ }^{31}$ P-NMR (162 MHz, $\left.\mathrm{CDCl}_{3}\right) \delta-7.08$. IR v 457; 594; 721; 771; 828; 883; 934; 966; 1029; 1141; 1237; 1297; 1464; 2852; 2921.

The previous compound $(200 \mathrm{mg}, 0.45 \mathrm{mmol})$ in $\mathrm{CHCl}_{3} / \mathrm{CH}_{3} \mathrm{CN} / i-$ $\mathrm{PrOH}$ 3:5:5 $(8 \mathrm{~mL})$ was treated with $45 \%(\mathrm{w} / \mathrm{w})$ aqueous trimethylamine $\left(3 \mathrm{~mL}, 20.2 \mathrm{mmol}\right.$ ) at $70^{\circ} \mathrm{C}$. After $24 \mathrm{~h}$, all starting material was consumed (checked by TLC). Volatile was removed under vacuum, the residue was extracted twice with $\mathrm{CHCl}_{3} / \mathrm{MeOH}$ 9/1 and the organic layer was washed with brine, reduced under vacuum, diluted with $\mathrm{CHCl}_{3}$, dried over $\mathrm{MgSO}_{4}$, filtered and evaporated. The crude residue was purified by flash chromatography $\left(\mathrm{CH}_{2} \mathrm{Cl}_{2} / \mathrm{MeOH} / \mathrm{H}_{2} \mathrm{O} \quad 75: 22: 3\right.$ to $\left.45: 45: 10\right)$ to yield erufosine (123 mg, $75 \%)$. $R_{\mathrm{f}}: 0.28\left(\mathrm{CH}_{2} \mathrm{Cl}_{2} / \mathrm{MeOH} / \mathrm{H}_{2} \mathrm{O}\right.$ 75:22:3). ${ }^{1} \mathrm{H}-\mathrm{NMR}$ $\left(400 \mathrm{MHz}, \mathrm{CD}_{3} \mathrm{OD} / \mathrm{CDCl}_{3} 1: 1\right) \delta 0.86(\mathrm{t}, J=6.2 \mathrm{~Hz}, 3 \mathrm{H}) ; 1.25(\mathrm{~m}, 30 \mathrm{H})$; $1.60\left(\mathrm{tt}, J_{1}=J_{2}=6.8 \mathrm{~Hz}, 2 \mathrm{H}\right) ; 2.00(\mathrm{~m}, 4 \mathrm{H}) ; 2.04(\mathrm{~m}, 2 \mathrm{H}) ; 3.11(\mathrm{~s}, 9 \mathrm{H}) ;$ $3.47(\mathrm{~m}, 2 \mathrm{H}) ; 3.82\left(\mathrm{td}, \mathrm{J}_{1}=\mathrm{J}_{2}=6.9 \mathrm{~Hz}, 2 \mathrm{H}\right) ; 3.90\left(\mathrm{td}, \mathrm{J}_{1}=\mathrm{J}_{2}=6.1 \mathrm{~Hz}, 2 \mathrm{H}\right)$; $5.31(\mathrm{~m}, 2 \mathrm{H}) .{ }^{13} \mathrm{C}-\mathrm{NMR}\left(100.7 \mathrm{MHz}, \mathrm{CD}_{3} \mathrm{OD} / \mathrm{CDCl}_{3} 1: 1\right) \delta 14.3 ; 23.2 ; 25.1$; 26.4; 27.7 (2C); 29.8 (2C); 29.9; 30.0; 30.1 (2C); $30.2(4 C) ; 30.3(2 \mathrm{C})$; $31.4 ; 32.4 ; 53.4$ (3C); 61.9; 64.9; 66.2; $130.3(2 \mathrm{C}) .{ }^{31} \mathrm{P}-\mathrm{NMR}(162 \mathrm{MHz}$, $\left.\mathrm{CD}_{3} \mathrm{OD} / \mathrm{CDCl}_{3} 1: 1\right) \delta+0.66 . \mathrm{IR} \vee 528 ; 553 ; 721 ; 840 ; 945 ; 1059 ; 1092 ;$ 1223; 1466; 1480; 1640; 2850; 2919; 3271. HR-MS (ESI+) m/z [M+H] calcd for $\mathrm{C}_{28} \mathrm{H}_{59} \mathrm{NO}_{4} \mathrm{P}^{+}$504.4176, found 504.4193 .

\section{Preparation of chloromethyl esters and 1-chloroethyl esters}

Typical procedure: Chloromethyl dodecanoate. Dodecanoyl chloride $(3.5 \mathrm{~mL}, 14.7 \mathrm{mmol}$ ) was added dropwise over $10 \mathrm{~min}$ to a mixture of anhydrous zinc chloride $(45 \mathrm{mg}, 0.29 \mathrm{mmol})$ and paraformaldehyde (663 mg, $22.1 \mathrm{mmol}$ ) at $0{ }^{\circ} \mathrm{C}$ under argon. After the addition was complete, the reaction mixture was stirred for $1 \mathrm{~h}$ at $0{ }^{\circ} \mathrm{C}$, and allowed to warm to room temperature overnight. The crude mixture was directly purified by flash chromatography ( $\mathrm{PE} / \mathrm{Et}_{2} \mathrm{O} 100: 0$ to $\left.95: 5\right)$ to provide chloromethyl dodecanoate $(2.61 \mathrm{~g}, 71 \%)$ as a colorless oil. $R_{\mathrm{f}}: 0.6\left(\mathrm{PE} / \mathrm{Et}_{2} \mathrm{O} 95: 5\right) .{ }^{1} \mathrm{H}-$ NMR $\left(400 \mathrm{MHz}, \mathrm{CDCl}_{3}\right) \delta 0.88(\mathrm{t}, J=6.8 \mathrm{~Hz}, 3 \mathrm{H}) ; 1.26(\mathrm{~m}, 16 \mathrm{H})$; 1.65 (tt, $J_{1}=J_{2}=7.2 \mathrm{~Hz}, 2 \mathrm{H}$ ); $2.38(\mathrm{t}, J=7.5 \mathrm{~Hz}, 2 \mathrm{H}) ; 5.70(\mathrm{~s}, 2 \mathrm{H}) .{ }^{13} \mathrm{C}-$ NMR $\left(100.7 \mathrm{MHz}, \mathrm{CDCl}_{3}\right) \delta 14.3 ; 22.8 ; 24.7 ; 29.1 ; 29.3 ; 29.5 ; 29.6$; 29.7 (2C); 32.1; 34.2; 68.7; 171.8. IR v 462; 718; 771; 1034; 1106; 1135; $1338 ; 1441 ; 1465 ; 1765 ; 2853 ; 2922$.

1-Chloroethyl dodecanoate. Paraformaldehyde was replaced by acetaldehyde. Yield: $42 \%$. $R_{\mathrm{f}}: 0.6\left(\mathrm{PE} / \mathrm{Et}_{2} \mathrm{O}\right.$ 95:5). ${ }^{1} \mathrm{H}-\mathrm{NMR}(400 \mathrm{MHz}$, $\left.\mathrm{CDCl}_{3}\right) \delta 0.88(\mathrm{t}, J=6.7 \mathrm{~Hz}, 3 \mathrm{H}) ; 1.26(\mathrm{~m}, 16 \mathrm{H}) ; 1.64\left(\mathrm{tt}, J_{1}=J_{2}=7.3 \mathrm{~Hz}\right.$, $2 \mathrm{H}) ; 1.78(\mathrm{~d}, J=5.8 \mathrm{~Hz}, 3 \mathrm{H}) ; 2.34(\mathrm{t}, J=7.5 \mathrm{~Hz}, 2 \mathrm{H}) ; 6.55(\mathrm{q}, J=5.8 \mathrm{~Hz}$ 1H). ${ }^{13} \mathrm{C}-\mathrm{NMR}\left(100.7 \mathrm{MHz}, \mathrm{CDCl}_{3}\right) \delta 14.3 ; 22.9 ; 24.8 ; 25.4 ; 29.2 ; 29.4$; $29.5 ; 29.6 ; 29.7 ; 29.8 ; 32.1 ; 34.4 ; 80.8 ; 171.8$. IR v 664; 721; $771 ; 934$; $1019 ; 1084 ; 1110 ; 1142 ; 1219 ; 1272 ; 1378 ; 1465 ; 1760 ; 2853 ; 2923$.

Chloromethyl acetate. Yield: $90 \% .{ }^{1} \mathrm{H}-\mathrm{NMR}\left(400 \mathrm{MHz}, \mathrm{CDCl}_{3}\right) \delta 2.14$ (s, $3 \mathrm{H}) ; 5.68$ (s, 2H). ${ }^{13} \mathrm{C}-\mathrm{NMR}\left(100.7 \mathrm{MHz}, \mathrm{CDCl}_{3}\right) \delta 20.8$; 68.7; 172.0. IR v $461 ; 598 ; 713 ; 818 ; 982 ; 1015 ; 1041 ; 1194 ; 1371 ; 1712 ; 1762$.

Chloromethyl hexanoate. Yield: $77 \% . R_{\mathrm{f}}: 0.75$ (PE/Et $\left.\mathrm{t}_{2} \mathrm{O} 75: 25\right) .{ }^{1} \mathrm{H}-\mathrm{NMR}$ $\left(400 \mathrm{MHz}, \mathrm{CDCl}_{3}\right) \quad \delta \quad 0.90(\mathrm{t}, \quad J=6.6 \mathrm{~Hz}, 3 \mathrm{H}) ; 1.32(\mathrm{~m}, 4 \mathrm{H})$; $1.65\left(\mathrm{tt}, J_{1}=J_{2}=7.2 \mathrm{~Hz}, 2 \mathrm{H}\right) ; 2.36(\mathrm{t}, J=7.5 \mathrm{~Hz}, 2 \mathrm{H}) ; 5.68(\mathrm{~s}, 2 \mathrm{H}) .{ }^{13} \mathrm{C}-$ NMR $\left(100.7 \mathrm{MHz}, \mathrm{CDCl}_{3}\right) \delta 14.1 ; 22.5 ; 24.4 ; 31.3 ; 34.2 ; 68.8 ; 172.0$. IR v 718; 773; 988; 1039; 1094; 1137; 1223; 1245; 1708; 1761; 2931; 2957.

Chloromethyl octanoate. Yield: $82 \%$. Rf : 0.75 (PE/Et2O 90:10). ${ }^{1} \mathrm{H}-\mathrm{NMR}$ $\left(400 \mathrm{MHz}, \quad \mathrm{CDCl}_{3}\right) \quad \delta \quad 0.88(\mathrm{t}, \quad J=6.6 \mathrm{~Hz}, \quad 3 \mathrm{H}) ; 1.30(\mathrm{~m}, \quad 8 \mathrm{H})$; $1.65\left(\mathrm{tt}, J_{1}=J_{2}=7.2 \mathrm{~Hz}, 2 \mathrm{H}\right) ; 2.38(\mathrm{t}, J=7.5 \mathrm{~Hz}, 2 \mathrm{H}) ; 5.68(\mathrm{~s}, 2 \mathrm{H}) .{ }^{13} \mathrm{C}-$ NMR $\left(100.7 \mathrm{MHz}, \mathrm{CDCl}_{3}\right) \delta 14.2 ; 22.7 ; 24.7 ; 30.0(2 \mathrm{C}) ; 31.7 ; 34.1 ; 68.7$; 171.9. IR v 462; 716; 1038; 1102; 1136; 1260; 1441; 1763; 2856; 2926.

Chloromethyl decanoate. Yield: $80 \% . R_{\mathrm{f}}: 0.75$ (PE/Et $\left.2 \mathrm{O} 90: 10\right) .{ }^{1} \mathrm{H}-\mathrm{NMR}$ $\left(400 \mathrm{MHz}, \quad \mathrm{CDCl}_{3}\right) \delta 0.88 \quad(\mathrm{t}, \quad J=6.8 \mathrm{~Hz}, 3 \mathrm{H}) ; 1.26(\mathrm{~m}, \quad 12 \mathrm{H})$; $1.65\left(\mathrm{tt}, J_{1}=J_{2}=7.3 \mathrm{~Hz}, 2 \mathrm{H}\right) ; 2.38(\mathrm{t}, J=7.5 \mathrm{~Hz}, 2 \mathrm{H}) ; 5.70(\mathrm{~s}, 2 \mathrm{H}) .{ }^{13} \mathrm{C}-$ NMR (100.7 MHz, $\left.\mathrm{CDCl}_{3}\right) \delta 14.3 ; 22.9 ; 24.8 ; 29.2 ; 29.4$ (2C); 29.6; 32.1; $34.2 ; 68.8 ; 172.0$. IR v 463; 718; 758; 1034; 1105; 1135; 1260; 1338; 1441; $1465 ; 1764 ; 2854 ; 2924$.

Chloromethyl tetradecanoate. Yield: $68 \% . R_{\mathrm{f}}: 0.75\left(\mathrm{PE} / \mathrm{Et}_{2} \mathrm{O} 90: 10\right) .{ }^{1} \mathrm{H}-$ NMR $\left(400 \mathrm{MHz}, \mathrm{CDCl}_{3}\right) \delta 0.88(\mathrm{t}, J=6.4 \mathrm{~Hz}, 3 \mathrm{H}) ; 1.26(\mathrm{~m}, 2 \mathrm{H})$; $1.65\left(\mathrm{tt}, J_{1}=J_{2}=7.2 \mathrm{~Hz}, 2 \mathrm{H}\right) ; 2.38(\mathrm{t}, J=7.5 \mathrm{~Hz}, 2 \mathrm{H}) ; 5.70(\mathrm{~s}, 2 \mathrm{H}) .{ }^{13} \mathrm{C}-$ NMR $\left(100.7 \mathrm{MHz}, \mathrm{CDCl}_{3}\right) \delta 14.3 ; 22.8 ; 24.7 ; 29.1 ; 29.3 ; 29.5 ; 29.6 ; 29.7$; 29.8 (3C); 32.1; 34.2; 68.7; 172.0. IR v 463; 719; 758; 1036; 1108; 1135; $1217 ; 1340 ; 1441 ; 1465 ; 1765 ; 2853 ; 2922$.

Chloromethyl hexadecanoate. Yield: $71 \% . R_{\mathrm{f}}: 0.75\left(\mathrm{PE} / \mathrm{Et}_{2} \mathrm{O} 90: 10\right) .{ }^{1} \mathrm{H}-$ NMR $\left(400 \mathrm{MHz}, \mathrm{CDCl}_{3}\right) \delta 0.88(\mathrm{t}, J=6.8 \mathrm{~Hz}, 3 \mathrm{H}) ; 1.26(\mathrm{~m}, 24 \mathrm{H})$; $1.65\left(\mathrm{tt}, J_{1}=J_{2}=7.2 \mathrm{~Hz}, 2 \mathrm{H}\right) ; 2.38(\mathrm{t}, J=7.6 \mathrm{~Hz}, 2 \mathrm{H}) ; 5.70(\mathrm{~s}, 2 \mathrm{H}) .{ }^{13} \mathrm{C}-$ $\operatorname{NMR}\left(100.7 \mathrm{MHz}, \mathrm{CDCl}_{3}\right) \delta 14.3 ; 22.8 ; 24.7 ; 29.1 ; 29.3 ; 29.5 ; 29.6 ; 29.7$; 29.8 (5C); 32.1; 34.2; 68.7; 171.9. IR v 437; 686; 718; 772; 994; 1017; $1035 ; 1098 ; 1147$; 1192; 1216; 1260; 1383; 1438; 1461; 1472; 1755; 2848; $2915 ; 2964$.

Chloromethyl octadecanoate. Yield: $76 \%$. $R_{\mathrm{f}}: 0.6$ (PE/Et $\left.2 \mathrm{O} 90: 10\right) .{ }^{1} \mathrm{H}-$ NMR $\left(400 \mathrm{MHz}, \mathrm{CDCl}_{3}\right) \delta 0.90(\mathrm{t}, J=6.7 \mathrm{~Hz}, 3 \mathrm{H}) ; 1.32(\mathrm{~m}, 28 \mathrm{H})$; $1.65\left(\mathrm{tt}, J_{1}=J_{2}=7.0 \mathrm{~Hz}, 2 \mathrm{H}\right) ; 2.36(\mathrm{t}, J=7.5 \mathrm{~Hz}, 2 \mathrm{H}) ; 5.68(\mathrm{~s}, 2 \mathrm{H}) .{ }^{13} \mathrm{C}-$ NMR $\left(100.7 \mathrm{MHz}, \mathrm{CDCl}_{3}\right) \delta 14.3 ; 22.8 ; 24.7 ; 29.1 ; 29.3 ; 29.5 ; 29.6 ; 29.7$; 29.8 (7C); 32.1; 34.2; 68.7; 171.9. IR v 686; 718; 793; 1017; 1035; 1045; $1099 ; 1147 ; 1191 ; 1259 ; 1383 ;$ 1438; 1462; 1472; 1755; 2848; 2916; 2959.

Chloromethyl oleate. Yield: $60 \%$. $R_{\mathrm{f}}: 0.5$ (PE/Et $\left.2 \mathrm{O} 95: 5\right) .{ }^{1} \mathrm{H}-\mathrm{NMR}(400$ $\left.\mathrm{MHz}, \mathrm{CDCl}_{3}\right) \delta 0.88(\mathrm{t}, J=6.7 \mathrm{~Hz}, 3 \mathrm{H}) ; 1.29(\mathrm{~m}, 2 \mathrm{H}) ; 1.65\left(\mathrm{tt}, \mathrm{J}_{1}=J_{2}=\right.$ $7.1 \mathrm{~Hz}, 2 \mathrm{H}) ; 2.01(\mathrm{~m}, 4 \mathrm{H}) ; 2.38(\mathrm{t}, \mathrm{J}=7.5 \mathrm{~Hz}, 2 \mathrm{H}) ; 5.34(\mathrm{~m}, 2 \mathrm{H}) ; 5.70(\mathrm{~s}$, 2H). ${ }^{13}$ C-NMR (100.7 MHz, CDCl $) \delta 14.3 ; 22.8 ; 24.7 ; 27.3(2 \mathrm{C}) ; 29.1 ; 29.2$ (2C); 29.5 (2C); $29.7 ; 29.8 ; 29.9 ; 32.1 ; 34.1 ; 68.7 ; 129.9 ; 130.2 ; 171.9$. IR v 462; 719; 771; 1036; 1093; 1114; 1219; 1260; 1338; 1440; 1463; 1766; 2853; 2922; 3003.

1-Chloroethyl oleate. Paraformaldehyde was replaced by acetaldehyde. Yield: $27 \% . R_{\mathrm{f}}: 0.5$ (PE/Et $\left.\mathrm{t}_{2} \mathrm{O} 95: 5\right) .{ }^{1} \mathrm{H}-\mathrm{NMR}\left(400 \mathrm{MHz}, \mathrm{CDCl}_{3}\right) \delta 0.88(\mathrm{t}$, $J=6.7 \mathrm{~Hz}, \quad 3 \mathrm{H}) ; \quad 1.28(\mathrm{~m}, \quad 20 \mathrm{H}) ; \quad 1.64\left(\mathrm{tt}, J_{1}=J_{2}=7.1 \mathrm{~Hz}, \quad 2 \mathrm{H}\right)$; $1.78(\mathrm{~d}, J=5 ; 8 \mathrm{~Hz}, \quad 3 \mathrm{H}) ; \quad 2.01 \quad(\mathrm{~m}, \quad 4 \mathrm{H}) ; \quad 2.34(\mathrm{t}, J=7.5 \mathrm{~Hz}, \quad 2 \mathrm{H}) ;$ $5.34(\mathrm{~m}, 2 \mathrm{H}) ; 6.55$ (q, $J=5.8 \mathrm{~Hz}, 1 \mathrm{H}) .{ }^{13} \mathrm{C}-\mathrm{NMR}\left(100.7 \mathrm{MHz}, \mathrm{CDCl}_{3}\right) \delta$ 14.3; 22.8; 24.7; 25.4; 27.4 (2C); 29.1; 29.2 (2C); 29.5 (2C); 29.7; 29.8; $29.9 ; 32.1 ; 34.3 ; 80.7 ; 129.9 ; 130.2 ; 171.6$. IR $\vee 666 ; 721 ; 772 ; 934 ; 1019$; 1083; 1137; 1220; 1272; 1378; 1463; 1761; 2853; 2922; 3004.

\section{Preparation of chloromethyl carbonates and 1-chloroethyl carbonates}

Typical procedure: Chloromethyl dodecyl carbonate. To a solution of dodecanol $(3.02 \mathrm{~g}, 16.2 \mathrm{mmol})$ and anhydrous $\mathrm{Et}_{3} \mathrm{~N}(4.5 \mathrm{~mL}, 32.0 \mathrm{mmol})$ in $\mathrm{Et}_{2} \mathrm{O}(35 \mathrm{~mL})$ at $0{ }^{\circ} \mathrm{C}$ under argon, chloromethylchloroformate $(2.2 \mathrm{~mL}$, $24.7 \mathrm{mmol})$ in anhydrous $\mathrm{Et}_{2} \mathrm{O}(10 \mathrm{~mL})$ was added dropwise over $15 \mathrm{~min}$. The resulting mixture was warmed to $\mathrm{rt}$ and stirred for $2 \mathrm{~h}$. Precipitate was 
discarded by filtration and the filtrate was reduced under vacuum. The crude residue was purified by flash column chromatography over silica gel (PE/Et ${ }_{2} \mathrm{O} 100: 0$ to $\left.95: 5\right)$ to yield chloromethyl dodecyl carbonate $(2.60 \mathrm{~g}$, $58 \%)$ as a clear oil. TLC $R_{\mathrm{f}} 0.50$ (PE/Et $\left.{ }_{2} \mathrm{O} 95: 5\right) .{ }^{1} \mathrm{H}-\mathrm{NMR}(400 \mathrm{MHz}$, $\left.\mathrm{CDCl}_{3}\right) \delta 0.88(\mathrm{t}, J=6.7 \mathrm{~Hz}, 3 \mathrm{H}) ; 1.26(\mathrm{~m}, 18 \mathrm{H}) ; 1.70\left(\mathrm{tt}, J_{1}=J_{2}=6.8 \mathrm{~Hz}\right.$, $2 \mathrm{H}$ ); 4.22 (t, $J=6.7 \mathrm{~Hz}, 2 \mathrm{H}) ; 5.73(\mathrm{~s}, 2 \mathrm{H}) .{ }^{13} \mathrm{C}-\mathrm{NMR}\left(100.7 \mathrm{MHz}, \mathrm{CDCl}_{3}\right) \delta$ 14.3; 22.9; 25.8; 28.7; 29.3; 29.5; 29.6; 29.7; 29.8 (2C); 32.1; 69.6; 72.3; 153.6. IR v $718 ; 787 ; 961 ; 1113 ; 1239 ; 1343 ; 1443 ; 1765 ; 2853 ; 2922$

1-Chloroethyl dodecyl carbonate. Chloromethyl chloroformate was replaced by 1-chloroethyl chloroformate. Yield: $58 \%$. $R_{\mathrm{f}}: 0.6\left(\mathrm{PE} / \mathrm{Et}_{2} \mathrm{O}\right.$ 95:5). ${ }^{1} \mathrm{H}-\mathrm{NMR}\left(400 \mathrm{MHz}, \mathrm{CDCl}_{3}\right) \delta 0.88(\mathrm{t}, J=6.8 \mathrm{~Hz}, 3 \mathrm{H}) ; 1.26(\mathrm{~m}, 18 \mathrm{H})$; $1.68\left(\mathrm{tt}, J_{1}=J_{2}=6.8 \mathrm{~Hz}, 2 \mathrm{H}\right) ; 1.83(\mathrm{~d}, J=5.8 \mathrm{~Hz}, 3 \mathrm{H}) ; 4.20(\mathrm{t}, J=6.7 \mathrm{~Hz}$, $2 \mathrm{H}) ; 6.43(\mathrm{q}, J=5.8 \mathrm{~Hz}, 1 \mathrm{H}) .{ }^{13} \mathrm{C}-\mathrm{NMR}\left(100.7 \mathrm{MHz}, \mathrm{CDCl}_{3}\right) \delta 14.3 ; 22.9$; $25.4 ; 25.8 ; 28.7 ; 29.3 ; 29.5 ; 29.6 ; 29.7 ; 29.8$ (2C); 32.1; 69.3; 84.7; 153.1. IR v 662; 785; 892; 1008; 1067; 1111; 1243; 1348; 1385; 1466; 1762; $2853 ; 2923$.

Chloromethyl oleyl carbonate. Yield: $80 \%$. $R_{\mathrm{f}}: 0.6\left(\mathrm{PE} / \mathrm{Et}_{2} \mathrm{O} 95: 5\right) .{ }^{1} \mathrm{H}-$ NMR (400 MHz, CDCl $)_{3} \delta 0.88(\mathrm{t}, J=6.7 \mathrm{~Hz}, 3 \mathrm{H}) ; 1.28(\mathrm{~m}, 22 \mathrm{H})$; $1.69\left(\mathrm{tt}, J_{1}=J_{2}=7.0 \mathrm{~Hz}, 2 \mathrm{H}\right) ; 2.01(\mathrm{~m}, 4 \mathrm{H}) ; 4.22(\mathrm{t}, J=6.8 \mathrm{~Hz}, 2 \mathrm{H}) ; 5.34$ $(\mathrm{m}, 2 \mathrm{H}) ; 5.72(\mathrm{~s}, 2 \mathrm{H}) .{ }^{13} \mathrm{C}-\mathrm{NMR}\left(100.7 \mathrm{MHz}, \mathrm{CDCl}_{3}\right) \delta 14.3 ; 22.8 ; 25.7$; 27.4 (2C); 28.6; 29.3 (2C); 29.5 (2C); 29.7 (2C); 29.8; 29.9; 31.9; 69.5; $72.3 ; 129.9 ; 130.2 ; 153.6$. IR v 719; 759; 787; 965; 1114; 1243; 1343; $1443 ; 1766 ; 2853 ; 2922 ; 3004$.

1-Chloroethyl oleyl carbonate. Chloromethyl chloroformate was replaced by 1-chloroethyl chloroformate. Yield: $85 \% . R_{\mathrm{f}}: 0.6\left(\mathrm{PE} / \mathrm{Et}_{2} \mathrm{O}\right.$ 95:5). ${ }^{1} \mathrm{H}-\mathrm{NMR}$ $\left(400 \mathrm{MHz}, \quad \mathrm{CDCl}_{3}\right) \quad \delta \quad 0.88 \quad(\mathrm{t}, \quad J=6.7 \mathrm{~Hz}, 3 \mathrm{H}) ; 1.29 \quad(\mathrm{~m}, \quad 22 \mathrm{H})$; $1.69\left(\mathrm{tt}, J_{1}=J_{2}=7.0 \mathrm{~Hz}, 2 \mathrm{H}\right) ; 1.83(\mathrm{~d}, J=5.8 \mathrm{~Hz}, 3 \mathrm{H}) ; 2.01(\mathrm{~m}, 4 \mathrm{H}) ; 4.20$ $(\mathrm{t}, J=6.8 \mathrm{~Hz}, 2 \mathrm{H}) ; 5.34(\mathrm{~m}, 2 \mathrm{H}) ; 6.43(\mathrm{q}, J=5.8 \mathrm{~Hz}, 1 \mathrm{H}) .{ }^{13} \mathrm{C}-\mathrm{NMR}(100.7$ $\left.\mathrm{MHz}, \mathrm{CDCl}_{3}\right) \delta 14.3 ; 22.8 ; 25.4 ; 25.8 ; 27.4(2 \mathrm{C}) ; 28.7 ; 29.3(2 \mathrm{C}) ; 29.5(2 \mathrm{C})$ $29.7 ; 29.9$ (3C); 31.9; 69.3; 84.6; 129.9; 130.2; 153.1. IR v 663; 722; 758; $894 ; 1008 ; 1111 ; 1245 ; 1348 ; 1384 ; 1464 ; 1763 ; 2853 ; 2922 ; 3004$.

\section{Preparation of erufosine prodrugs}

General procedure. Electrophilic reagent $(4.0 \mathrm{mmol})$ and erufosine $(0.5 \mathrm{mmol})$ were reacted in refluxing anhydrous $\mathrm{CHCl}_{3}(12 \mathrm{~mL})$ for $24 \mathrm{~h}$ with stirring under inert atmosphere. The solvent was removed under vacuum and the crude residue was purified by flash chromatography $\left(\mathrm{CH}_{2} \mathrm{Cl}_{2} / \mathrm{MeOH} 10: 0\right.$ to $\left.7: 3\right)$ to yield the corresponding pro-erufosine.

\section{3-(((Dodecyloxy)(erucyloxy)phosphoryl)oxy)-N,N,N-trimethylpropan-1-} aminium triflate $\left(\boldsymbol{E}_{12}\right)$. Compound $\mathbf{E}_{12}(139 \mathrm{mg}, 97 \%)$ was obtained from erufosine $(102 \mathrm{mg}, \quad 0.16 \mathrm{mmol})$ and dodecyl triflate ${ }^{[[50]]}(170 \mathrm{mg}$, $0.53 \mathrm{mmol}$ ) according to the general procedure except the reaction was conducted at rt. $R_{\mathrm{f}}: 0.7\left(\mathrm{CH}_{2} \mathrm{Cl}_{2} / \mathrm{MeOH} / \mathrm{H}_{2} \mathrm{O} 75: 22: 3\right) .{ }^{1} \mathrm{H}-\mathrm{NMR}(400 \mathrm{MHz}$, $\left.\mathrm{CDCl}_{3}\right) \delta 0.88(\mathrm{t}, J=6.6 \mathrm{~Hz}, 6 \mathrm{H}) ; 1.26(\mathrm{~m}, 48 \mathrm{H}) ; 1.67\left(\mathrm{tt}, J_{1}=J_{2}=6.8 \mathrm{~Hz}\right.$, $4 \mathrm{H}) ; 2.02(\mathrm{~m}, 4 \mathrm{H}) ; 2.20(\mathrm{~m}, 2 \mathrm{H}) ; 3.24(\mathrm{~s}, \quad 9 \mathrm{H}) ; 3.55(\mathrm{~m}, 2 \mathrm{H}) ;$ $4.04\left(\mathrm{td}, J_{1}=J_{2}=6.8 \mathrm{~Hz}, 4 \mathrm{H}\right) ; 4.14\left(\mathrm{td}, J_{1}=J_{2}=6.8 \mathrm{~Hz}, 2 \mathrm{H}\right) ; 5.35(\mathrm{~m}, 2 \mathrm{H})$. ${ }^{13} \mathrm{C}-\mathrm{NMR}\left(100.7 \mathrm{MHz}, \mathrm{CDCl}_{3}\right) \delta 14.4(2 \mathrm{C}) ; 22.8(2 \mathrm{C}) ; 24.5 ; 25.6$ (2C); 27.4 (2C); 29.3 (2C); 29.5 (4C); 29.8 (5C); 29.9 (5C); 30.0 (2C); $30.4(2 \mathrm{C})$; 32.1 (2C); $53.6(3 \mathrm{C}) ; 63.8 ; 64.1 ; 68.5 ; 68.6 ; 130.0 ; 130.1 .{ }^{31} \mathrm{P}-\mathrm{NMR} \delta(162$ $\left.\mathrm{MHz}, \mathrm{CDCl}_{3}\right) \delta-1.43$. IR v 516; $572 ; 638 ; 772 ; 866 ; 1030 ; 1158 ; 1225$; $1257 ; 1465 ; 2852 ; 2921 ; 3500$. HR-MS (ESI+) $\mathrm{m} / \mathrm{z}[\mathrm{M}-\mathrm{Cl}]^{+}$calcd for $\mathrm{C}_{40} \mathrm{H}_{83} \mathrm{NO}_{4} \mathrm{P}^{+} 672.6054$, found 672.6039 .

3-((((Dodecanoyloxy)methoxy)(erucyloxy)phosphoryl)oxy)-N,N,Ntrimethylpropan-1-aminium chloride $\left(E_{E 12}\right)$. Compound $\mathbf{E}_{\mathrm{E} 12}$ (124 mg, $41 \%$ ) was obtained from erufosine $(201 \mathrm{mg}, 0.40 \mathrm{mmol})$ and chloromethyl dodecanoate $\left(791 \mathrm{mg}, 3.17 \mathrm{mmol}\right.$ ) according to the general procedure. $R_{\mathrm{f}}$ : $0.5\left(\mathrm{CH}_{2} \mathrm{Cl}_{2} / \mathrm{MeOH} / \mathrm{H}_{2} \mathrm{O} 75: 22: 3\right)$. ${ }^{1} \mathrm{H}-\mathrm{NMR}\left(400 \mathrm{MHz}, \mathrm{CD}_{3} \mathrm{OD} / \mathrm{CDCl}_{3} 1: 1\right)$ $\delta 0.86(\mathrm{t}, J=6.8 \mathrm{~Hz}, 6 \mathrm{H}) ; 1.25(\mathrm{~m}, 46 \mathrm{H}) ; 1.63\left(\mathrm{tt}, J_{1}=J_{2}=6.8 \mathrm{~Hz}, 2 \mathrm{H}\right)$ $1.68\left(\mathrm{tt}, \quad J_{1}=J_{2}=7.4 \mathrm{~Hz}, 2 \mathrm{H}\right) ; 1.99(\mathrm{~m}, 4 \mathrm{H}) ; 2.19(\mathrm{~m}, 2 \mathrm{H}) ; 2.40(\mathrm{t}$, $J=7.5 \mathrm{~Hz}, 2 \mathrm{H}) ; 3.16(\mathrm{~s}, 9 \mathrm{H}) ; 3.49(\mathrm{~m}, 2 \mathrm{H}) ; 4.07$ (td, $\left.J_{1}=J_{2}=6.9 \mathrm{~Hz}, 2 \mathrm{H}\right)$ $4.17\left(\mathrm{td}, J_{1}=J_{2}=6.9 \mathrm{~Hz}, 2 \mathrm{H}\right) ; 5.31(\mathrm{~m}, 2 \mathrm{H}) ; 5.62$ (ABX syst., $J_{A B}=5.2 \mathrm{~Hz}$, $\left.J_{A X}=13.4 \mathrm{~Hz}, J_{B X}=11.4 \mathrm{~Hz}, 2 \mathrm{H}\right) .{ }^{13} \mathrm{C}-\mathrm{NMR} \delta\left(100.7 \mathrm{MHz}, \mathrm{CD}_{3} \mathrm{OD} / \mathrm{CDCl}_{3}\right.$ $1: 1) \delta 14.5$ (2C); 23.3 (2C); 24.8; 25.3; 26.1; 27.8 (2C); 29.7; 29.8; 30.0 (5C); 30.2; $30.3(6 \mathrm{C}) ; 30.4(2 \mathrm{C}) ; 30.5$ (2C); 30.9; 32.6 (2C); 34.6; 53.7 (3C); $64.3 ; 65.5 ; 69.9 ; 83.5 ; 130.5 ; 130.6 ; 173.2$. ${ }^{31} \mathrm{P}-\mathrm{NMR}(162 \mathrm{MHz}$, $\mathrm{CD}_{3} \mathrm{OD} / \mathrm{CDCl}_{3}$ 1:1) $\delta-3.38$. IR $\vee 491 ; 721 ; 757 ; 858 ; 968 ; 1029 ; 1116$; $1157 ; 1261 ; 1466 ; 1760 ; 2850 ; 2919 ; 2956 ; 3389$. HR-MS (ESI+) m/z [M$\mathrm{Cl}]^{+}$calcd for $\mathrm{C}_{41} \mathrm{H}_{83} \mathrm{NO}_{6} \mathrm{P}^{+} 716.5953$, found 716.5954 .

\section{3-(((1-(Dodecanoyloxy)ethoxy)(erucyloxy)phosphoryl)oxy)-N,N,N-} trimethylpropan-1-aminium chloride $\left(\boldsymbol{E}_{E^{\prime} 12}\right)$. Compound $\mathbf{E}_{\mathrm{E}^{\prime} 12}(152 \mathrm{mg}$, $50 \%$ ) was obtained as a mixture of four diastereomers from erufosine (201 $\mathrm{mg}, 0.40 \mathrm{mmol}$ ) and 1-chloroethyl dodecanoate $(841 \mathrm{mg}, 3.20 \mathrm{mmol})$ according to the general procedure. $R_{\mathrm{f}}: 0.4$ and $0.5\left(\mathrm{CH}_{2} \mathrm{Cl}_{2} / \mathrm{MeOH} / \mathrm{H}_{2} \mathrm{O}\right.$ 75:22:3). ${ }^{1} \mathrm{H}-\mathrm{NMR}\left(400 \mathrm{MHz}, \mathrm{CD}_{3} \mathrm{OD} / \mathrm{CDCl}_{3} 1: 1\right) \delta 0.86(\mathrm{t}, J=6.8 \mathrm{~Hz}, 6 \mathrm{H}$ ); $1.25(\mathrm{~m}, 46 \mathrm{H}) ; 1.56(\mathrm{~d}, J=5.2 \mathrm{~Hz}, 3 \mathrm{H}) ; 1.63\left(\mathrm{tt}, J_{1}=J_{2}=6.8 \mathrm{~Hz}, 2 \mathrm{H}\right) ; 1.68$ (tt, $\left.J_{1}=J_{2}=7.4 \mathrm{~Hz}, 2 \mathrm{H}\right) ; 1.99(\mathrm{~m}, 4 \mathrm{H}) ; 2.19(\mathrm{~m}, 2 \mathrm{H}) ; 2.36(\mathrm{t}, J=7.4 \mathrm{~Hz}$, $2 \mathrm{H}) ; 3.17(\mathrm{~s}, 9 \mathrm{H}) ; 3.52(\mathrm{~m}, 2 \mathrm{H}) ; 4.07\left(\mathrm{td}, J_{1}=J_{2}=6.9 \mathrm{~Hz}, 2 \mathrm{H}\right) ; 4.17(\mathrm{~m}$, $2 \mathrm{H}) ; 5.30(\mathrm{~m}, 2 \mathrm{H}) ; 6.44\left(\mathrm{qd}, J_{1}=J_{2}=5.2 \mathrm{~Hz}, 1 \mathrm{H}\right) .{ }^{13} \mathrm{C}-\mathrm{NMR}(100.7 \mathrm{MHz}$ $\left.\mathrm{CD}_{3} \mathrm{OD} / \mathrm{CDCl}_{3} 1: 1\right) \delta 14.4(2 \mathrm{C}) ; 21.7 ; 23.3(2 \mathrm{C}) ; 24.8 ; 25.3 ; 26.1 ; 27.8$ (2C); 29.7; 29.8; 30.0 (5C); 30.2 (4C); 30.3 (5C); 30.4 (2C); 30.9; 32.6 (2C); $34.7 ; 53.7$ (3C); 64.3; 65.2; 69.6; 92.0; 130.5 (2C); 173.7. ${ }^{31} \mathrm{P}-\mathrm{NMR} \delta(162$ $\left.\mathrm{MHz}, \mathrm{CD}_{3} \mathrm{OD} / \mathrm{CDCl}_{3} 1: 1\right) \delta-5.15$ and -5.85 . IR v 515; 721; 850; 969; 1041 ; 1090; 1167;1269; 1379; 1466; 1753; 2850; 2919; 3388. HR-MS $(\mathrm{ESI}+) \mathrm{m} / \mathrm{z}[\mathrm{M}-\mathrm{Cl}]^{+}$calcd for $\mathrm{C}_{42} \mathrm{H}_{85} \mathrm{NO}_{6} \mathrm{P}^{+} 730.6109$, found 730.6120 .

\section{3-(((((Dodecyloxy)carbonyl)oxy)methoxy)(erucyloxy)phosphoryl)oxy)-} $\mathrm{N}, \mathrm{N}, \mathrm{N}$-trimethylpropan-1-aminium chloride $\left(E_{c 12}\right)$. Compound $\mathrm{E}_{\mathrm{c} 12}(97 \mathrm{mg}$, $31 \%$ ) was obtained from erufosine $(200 \mathrm{mg}, 0.40 \mathrm{mmol})$ and chloromethyl dodecyl carbonate $(884 \mathrm{mg}, 3.17 \mathrm{mmol})$ according to the general procedure. $R_{\mathrm{f}}: 0.45\left(\mathrm{CH}_{2} \mathrm{Cl}_{2} / \mathrm{MeOH} / \mathrm{H}_{2} \mathrm{O}\right.$ 75:22:3). ${ }^{1} \mathrm{H}-\mathrm{NMR}(400 \mathrm{MHz}$, $\left.\mathrm{CD}_{3} \mathrm{OD} / \mathrm{CDCl}_{3} 1: 1\right) \delta 0.88(\mathrm{t}, J=6.6 \mathrm{~Hz}, 6 \mathrm{H}) ; 1.27(\mathrm{~m}, 48 \mathrm{H}) ; 1.68(\mathrm{~m}$, $4 \mathrm{H}) ; 2.00(\mathrm{~m}, 4 \mathrm{H}) ; 2.21(\mathrm{~m}, 2 \mathrm{H}) ; 3.17(\mathrm{~s}, 9 \mathrm{H}) ; 3.50(\mathrm{~m}, 2 \mathrm{H})$; $4.10\left(\mathrm{td}, \mathrm{J}_{1}=\mathrm{J}_{2}=6.8 \mathrm{~Hz}, 2 \mathrm{H}\right) ; 4.17(\mathrm{t}, J=6.4 \mathrm{~Hz}, 2 \mathrm{H}) ; 4.25(\mathrm{~m}, 2 \mathrm{H}) ; 5.32$ $(\mathrm{m}, 2 \mathrm{H}) ; 5.65(\mathrm{~m}, 2 \mathrm{H}) .{ }^{13} \mathrm{C}-\mathrm{NMR} \delta\left(100.7 \mathrm{MHz}, \mathrm{CD}_{3} \mathrm{OD} / \mathrm{CDCl}_{3} 1: 1\right) \delta 14.6$ (2C); 23.6 (2C); 25.0; 26.3; 26.6; 28.0 (2C); 29.5; 30.1; 30.2 (2C); 30.3 (2C); 30.4; 30.5 (4C); $30.6(6 \mathrm{C}) ; 30.7(2 \mathrm{C}) ; 31.1 ; 32.8(2 \mathrm{C}) ; 53.8(3 \mathrm{C})$; $64.5 ; 65.9 ; 70.2(2 \mathrm{C}) ; 86.8 ; 130.7 ; 130.7 ; 156.0 .{ }^{31} \mathrm{P}-\mathrm{NMR}(162 \mathrm{MHz}$, $\left.\mathrm{CD}_{3} \mathrm{OD} / \mathrm{CDCl}_{3} 1: 1\right) \delta-3.06$. IR $\vee 490 ; 721 ; 790 ; 860 ; 946 ; 1024 ; 1115$; $1257 ; 1466 ; 1761 ; 2852 ; 2920 ; 3399$. HR-MS (ESI+) m/z [M-Cl] ${ }^{+}$calcd for $\mathrm{C}_{42} \mathrm{H}_{85} \mathrm{NO}_{7} \mathrm{P}^{+} 746.6058$, found 746.6069 .

\section{3-(((1-((((Dodecyloxy)carbonyl)oxy)ethoxy))(erucyloxy)phosphoryl)oxy)-} $N, N, N$-trimethylpropan-1-aminium chloride $\left(E_{\left.C^{\prime} 12\right)}\right.$. Compound $E_{C^{\prime} 12}$ (128 $\mathrm{mg}, 41 \%$ ) was obtained as a mixture of four diastereomers from erufosine $(199 \mathrm{mg}, 0.39 \mathrm{mmol})$ and 1-chloroethyl dodecyl carbonate $(923 \mathrm{mg}, 3.15 \mathrm{mmol})$ according to the general procedure. $R_{\mathrm{f}}: 0.45$ $\left(\mathrm{CH}_{2} \mathrm{Cl}_{2} / \mathrm{MeOH} / \mathrm{H}_{2} \mathrm{O}\right.$ 75:22:3). ${ }^{1} \mathrm{H}-\mathrm{NMR}\left(400 \mathrm{MHz}, \mathrm{CD}_{3} \mathrm{OD} / \mathrm{CDCl}_{3} 1: 1\right) \delta$ 0.86 (t, $J=6.8 \mathrm{~Hz}, 6 \mathrm{H}) ; 1.25(\mathrm{~m}, 48 \mathrm{H}) ; 1.59(\mathrm{~d}, J=5.2 \mathrm{~Hz}, 3 \mathrm{H})$; $1.67(\mathrm{~m}, 4 \mathrm{H}) ; 2.00(\mathrm{~m}, 4 \mathrm{H}) ; 2.19(\mathrm{~m}, 2 \mathrm{H}) ; 3.17(\mathrm{~s}, 9 \mathrm{H}) ; 3.50(\mathrm{~m}, 2 \mathrm{H}) ; 4.07$ (m, 2H); $4.16(\mathrm{~m}, 2 \mathrm{H}) ; 4.20(\mathrm{~m}, 2 \mathrm{H}) ; 5.30(\mathrm{~m}, 2 \mathrm{H}) ; 6.34(\mathrm{~m}, 1 \mathrm{H}) .{ }^{13} \mathrm{C}-\mathrm{NMR}$ $\delta\left(100.7 \mathrm{MHz}, \mathrm{CD}_{3} \mathrm{OD} / \mathrm{CDCl}_{3} 1: 1\right) \delta 14.6(2 \mathrm{C}) ; 21.5 ; 23.6(2 \mathrm{C}) ; 25.0 ; 26.3$; 26.6; 28.0 (2C); 29.5; 29.9 (3C); 30.0 (3C); 30.2 (2C); 30.3 (2C); 30.4 (6C); 30.5 (2C); 30.8; 32.6 (2C); 53.7 (3C); 64.3; 65.3; 69.8 (2C); 95.5; 130.5 (2C); $156.8 .{ }^{31} \mathrm{P}-\mathrm{NMR}\left(162 \mathrm{MHz}, \mathrm{CD}_{3} \mathrm{OD} / \mathrm{CDCl}_{3} 1: 1\right) \delta-5.16$ and -5.31 . IR v 515; 720; 789; 889; 969; 1030; 1259; 1393; 1465; 1757; 2852; 2921; 3387. HR-MS (ESI+) m/z [M-Cl] calcd for $\mathrm{C}_{43} \mathrm{H}_{87} \mathrm{NO}_{7} \mathrm{P}^{+} 760.6215$, found 760.6221.

3-(((Erucyloxy)((oleoyloxy)methoxy)phosphoryl)oxy)-N,N,Ntrimethylpropan-1-aminium chloride $\left(E_{E 18: 1}\right)$. Compound $E_{E 18: 1}(115 \mathrm{mg}$, 
$35 \%$ ) was obtained from erufosine (200 $\mathrm{mg}, 0.40 \mathrm{mmol}$ ) and chloromethyl oleate $(1.05 \mathrm{~g}, 3.17 \mathrm{mmol})$ according to the general procedure. $R_{\mathrm{f}}: 0.65$ $\left(\mathrm{CH}_{2} \mathrm{Cl}_{2} / \mathrm{MeOH} / \mathrm{H}_{2} \mathrm{O}\right.$ 75:22:3). ${ }^{1} \mathrm{H}-\mathrm{NMR}\left(400 \mathrm{MHz}, \mathrm{CDCl}_{3}\right) \delta 0.88$ (t, $J=7.0 \mathrm{~Hz}, 6 \mathrm{H}) ; 1.27(\mathrm{~m}, 50 \mathrm{H}) ; 1.63\left(\mathrm{tt}, J_{1}=J_{2}=6.8 \mathrm{~Hz}, 2 \mathrm{H}\right) ; 1.68$ (tt, $\left.J_{1}=J_{2}=7.4 \mathrm{~Hz}, 2 \mathrm{H}\right) ; 2.00(\mathrm{~m}, 8 \mathrm{H}) ; 2.28(\mathrm{~m}, 2 \mathrm{H}) ; 2.38(\mathrm{t}, J=7.5 \mathrm{~Hz}, 2 \mathrm{H}) ;$ 3.48 (s, 9H); 3.81 (m, 2H); 4.07 (td, $\left.J_{1}=J_{2}=6.9 \mathrm{~Hz} ; 2 \mathrm{H}\right) ; 4.23(\mathrm{~m}, 2 \mathrm{H})$; $5.34\left(\mathrm{~m}, 4 \mathrm{H}\right.$ ); 5.62 (ABX syst., $J_{A B}=4.8 \mathrm{~Hz}, J_{A X}=12.7 \mathrm{~Hz}, J_{B X}=10.9 \mathrm{~Hz}$, 2H). ${ }^{13} \mathrm{C}-\mathrm{NMR} \delta\left(100.7 \mathrm{MHz}, \mathrm{CDCl}_{3}\right) \delta 14.3(2 \mathrm{C}) ; 22.9$ (2C); 24.5 (C); 24.7 (C); 25.6; 27.4 (4C); 29.2; 29.3; 29.4; 29.5 (7C); 29.7 (5C); 29.8 (3C); 29.9 (2C); 30.4; 32.1 (2C); 34.2; 53.8 (3C); 63.7; 64.7; 69.1; 82.8; 129.8; 130.0; 130.1; 130.3; 172.4. ${ }^{31} \mathrm{P}-\mathrm{NMR}\left(162 \mathrm{MHz}, \mathrm{CDCl}_{3}\right) \delta-3.42$. IR v 495; 721; 796; 844; 970; 1055; 1146; 1241; 1465; 1647; 1750; 2852; 2921; 3387. HR-MS (ESI+) m/z [M-Cl] ${ }^{+}$calcd for $\mathrm{C}_{47} \mathrm{H}_{93} \mathrm{NO}_{6} \mathrm{P}^{+} 798.6735$, found 798.6739 .

\section{3-(((Erucyloxy)(1-(oleoyloxy)ethoxy)phosphoryl)oxy)-N,N,N-}

trimethylpropan-1-aminium chloride $\left(E_{\left.E^{\prime} 18: 1\right)}\right.$. Compound $E_{E^{\prime} 18: 1}$ (158 mg, $47 \%$ ) was obtained as two separated couples of enantiomers from erufosine $(200 \mathrm{mg}, 0.40 \mathrm{mmol})$ and 1-chloroethyl oleate $(995 \mathrm{mg}$, $2.88 \mathrm{mmol}$ ) according to the general procedure. $R_{\mathrm{f}}: 0.7$ (E1) and 0.65 (E2) $\left(\mathrm{CH}_{2} \mathrm{Cl}_{2} / \mathrm{MeOH} / \mathrm{H}_{2} \mathrm{O}\right.$ 75:22:3). ${ }^{1} \mathrm{H}-\mathrm{NMR}\left(400 \mathrm{MHz}, \mathrm{CD}_{3} \mathrm{OD} / \mathrm{CDCl}_{3} 1: 1\right) \mathrm{E} 1$ $\delta 0.86(\mathrm{t}, J=7.0 \mathrm{~Hz}, 6 \mathrm{H}) ; 1.25(\mathrm{~m}, 50 \mathrm{H}) ; 1.55(\mathrm{~d}, J=5.3 \mathrm{~Hz}, 3 \mathrm{H}) ; 1.61$ (tt, $\left.J_{1}=J_{2}=6.8 \mathrm{~Hz}, 2 \mathrm{H}\right) ; 1.68\left(\mathrm{tt}, J_{1}=J_{2}=7.4 \mathrm{~Hz}, 2 \mathrm{H}\right) ; 2.00(\mathrm{~m}, 8 \mathrm{H}) ; 2.18(\mathrm{~m}$, $2 \mathrm{H}$ ); 2.36 (t, $J=7.4 \mathrm{~Hz}, 2 \mathrm{H}) ; 3.18(\mathrm{~s} ; 9 \mathrm{H}) ; 3.52(\mathrm{~m}, 2 \mathrm{H}) ; 4.04$ (td, $\left.J_{1}=J_{2}=6.9 \mathrm{~Hz}, 2 \mathrm{H}\right) ; 4.16(\mathrm{~m}, 2 \mathrm{H}) ; 5.31(\mathrm{~m}, 4 \mathrm{H}) ; 6.44\left(\mathrm{dq}, J_{1}=J_{2}=5.3 \mathrm{~Hz}\right.$ 1H). ${ }^{1} \mathrm{H}-\mathrm{NMR}\left(400 \mathrm{MHz}, \mathrm{CD}_{3} \mathrm{OD} / \mathrm{CDCl}_{3} 1: 1\right) \mathrm{E} 2 \delta 0.86(\mathrm{t}, J=7.0 \mathrm{~Hz}, 6 \mathrm{H})$; $1.25(\mathrm{~m}, 50 \mathrm{H}) ; 1.55(\mathrm{~d}, J=5.3 \mathrm{~Hz}, 3 \mathrm{H}) ; 1.61\left(\mathrm{tt}, J_{1}=J_{2}=6.8 \mathrm{~Hz}, 2 \mathrm{H}\right) ; 1.68$ (tt, $\left.J_{1}=J_{2}=7.4 \mathrm{~Hz}, 2 \mathrm{H}\right) ; 2.00(\mathrm{~m}, 8 \mathrm{H}) ; 2.18(\mathrm{~m}, 2 \mathrm{H}) ; 2.36$ (t, $J=7.4 \mathrm{~Hz}$ $2 \mathrm{H}) ; 3.18(\mathrm{~s}, 9 \mathrm{H}) ; 3.52(\mathrm{~m}, 2 \mathrm{H}) ; 4.04\left(\mathrm{td}, J_{1}=J_{2}=6.9 \mathrm{~Hz}, 2 \mathrm{H}\right) ; 4.16(\mathrm{~m}$, $2 \mathrm{H}) ; 5.31(\mathrm{~m}, 4 \mathrm{H}) ; 6.45\left(\mathrm{dq}, \mathrm{J}_{1}=\mathrm{J}_{2}=5.3 \mathrm{~Hz}, 1 \mathrm{H}\right) .{ }^{13} \mathrm{C}-\mathrm{NMR} \delta(100.7 \mathrm{MHz}$, $\mathrm{CD}_{3} \mathrm{OD} / \mathrm{CDCl}_{3}$ 1:1) E1 $\delta 14.5(2 \mathrm{C}) ; 21.7 ; 23.3(2 \mathrm{C}) ; 24.8 ; 25.3 ; 26.0 ; 27.8$ (4C); 29.7; 29.8 (3C); 30.0 (3C); 30.2 (4C); 30.3 (5C); 30.4 (4C); 30.9; 32.6 (2C); 34.7; 53.7 (3C); 64.3; 65.2; 69.6; 92.0; 130.3; 130.5; 130.6; 130.7; 173.0. ${ }^{13} \mathrm{C}-\mathrm{NMR} \delta\left(100.7 \mathrm{MHz}, \mathrm{CD}_{3} \mathrm{OD} / \mathrm{CDCl}_{3} 1: 1\right) \mathrm{E} 2 \delta 14.5(2 \mathrm{C}) ; 21.7$; 23.3 (2C); 24.8; 25.1; 26.0; 27.8 (4C); 29.7; 29.8 (3C); 30.0 (3C); 30.2 (4C); 30.3 (5C); 30.4 (4C); 30.9; 32.6 (2C); 34.5; 53.7 (3C); 64.3; 65.2; 69.6; 92.0; $130.3 ; 130.5 ; 130.6 ; 130.7 ; 172.8$. ${ }^{{ }^{1}} \mathrm{P}-\mathrm{NMR}$ (162 MHz, $\left.\mathrm{CD}_{3} \mathrm{OD} / \mathrm{CDCl}_{3} 1: 1\right) \delta-5.16(\mathrm{E} 1) ;-5.68(\mathrm{E} 2)$. IR $v 516 ; 721 ; 849 ; 968$; $1030 ; 1082 ; 1160 ; 1270 ; 1465 ; 1754 ; 2852 ; 2921 ; 3377$. HR-MS (ESI+) $\mathrm{m} / \mathrm{z}[\mathrm{M}-\mathrm{Cl}]^{+}$calcd for $\mathrm{C}_{48} \mathrm{H}_{95} \mathrm{NO}_{6} \mathrm{P}^{+} 812.6892$, found 812.6883 .

3-(((Erucyloxy))(((oleyloxy)carbonyl)oxy)methoxy)phosphoryl)oxy)-N,N,Ntrimethylpropan-1-aminium chloride $\left(\boldsymbol{E}_{c 18: 1)}\right.$. Compound $\mathbf{E}_{\mathrm{c18:1}}$ (200 mg, $58 \%$ ) was obtained from erufosine $(200 \mathrm{mg}, 0.40 \mathrm{mmol})$ and chloromethyl oleyl carbonate $(1.16 \mathrm{~g}, 3.18 \mathrm{mmol})$ according to the general procedure. $R_{\mathrm{f}}: 0.65\left(\mathrm{CH}_{2} \mathrm{Cl}_{2} / \mathrm{MeOH} / \mathrm{H}_{2} \mathrm{O} 75: 22: 3\right) .{ }^{1} \mathrm{H}-\mathrm{NMR}\left(400 \mathrm{MHz}, \mathrm{CDCl}_{3}\right) \delta 0.88$ $(\mathrm{t}, J=6.6 \mathrm{~Hz}, 6 \mathrm{H}) ; 1.26(\mathrm{~m}, 52 \mathrm{H}) ; 1.68\left(\mathrm{tt}, J_{1}=J_{2}=6.8 \mathrm{~Hz}, 4 \mathrm{H}\right) ; 2.00(\mathrm{~m}$, $8 \mathrm{H}) ; 2.29(\mathrm{~m}, 2 \mathrm{H}) ; 3.49(\mathrm{~s}, 9 \mathrm{H}) ; 3.78(\mathrm{~m}, 2 \mathrm{H}) ; 4.07\left(\mathrm{td}, \mathrm{J}_{1}=\mathrm{J}_{2}=6.8 \mathrm{~Hz}\right.$, $2 \mathrm{H}) ; 4.18(\mathrm{t}, J=6.8 \mathrm{~Hz}, 2 \mathrm{H}) ; 4.21(\mathrm{~m}, 2 \mathrm{H}) ; 5.34(\mathrm{~m}, 4 \mathrm{H}) ; 5.63(\mathrm{~m}, 2 \mathrm{H}) .{ }^{13} \mathrm{C}-$ NMR $\delta\left(100.7 \mathrm{MHz}, \mathrm{CDCl}_{3}\right) \delta 14.3(2 \mathrm{C}) ; 22.9(2 \mathrm{C}) ; 24.6 ; 25.4 ; 25.6 ; 27.4$ (4C); 28.7; 29.4 (3C); 29.5 (4C); 29.6; 29.8 (4C); 29.9 (4C); 30.0 (4C); 30.3; 32.1 (2C); 53.7 (3C); 63.7; 64.7; 69.2; 69.5; 85.8; 129.9; 130.0; 130.1; 130.2; 153.1. ${ }^{31} \mathrm{P}-\mathrm{NMR}\left(162 \mathrm{MHz}, \mathrm{CDCl}_{3}\right) \delta-3.03$. IR v 502; 721; 772; $858 ; 947 ; 1027 ; 1155 ; 1256 ; 1464 ; 1761 ; 2852 ; 2921 ; 3390$. HR-MS (ESI+) $\mathrm{m} / \mathrm{z}[\mathrm{M}-\mathrm{Cl}]^{+}$calcd for $\mathrm{C}_{48} \mathrm{H}_{95} \mathrm{NO}_{7} \mathrm{P}^{+} 828.6841$, found 828.6837 .

\section{3-(((Erucyloxy)(1-((((oleyloxy)carbonyl)oxy)ethoxy))phosphoryl)oxy)-}

$N, N, N$-trimethylpropan-1-aminium chloride $\left(E_{C^{\prime} 18: 1}\right)$. Compound $E_{C^{\prime} 18: 1}$ (169 mg, $49 \%$ ) was obtained as two separated couples of enantiomers from erufosine $(199 \mathrm{mg}, 0.40 \mathrm{mmol})$ and 1-chloroethyl oleyl carbonate $(1.18 \mathrm{mg}, 3.14 \mathrm{mmol})$ according to the general procedure. $R_{\mathrm{f}}: 0.7$ (E1) and 0.6 (E2) $\left(\mathrm{CH}_{2} \mathrm{Cl}_{2} / \mathrm{MeOH} / \mathrm{H}_{2} \mathrm{O} 75: 22: 3\right)$. ${ }^{1} \mathrm{H}-\mathrm{NMR}\left(400 \mathrm{MHz}, \mathrm{CDCl}_{3}\right) \mathrm{E} 1 \delta$ $0.88(\mathrm{t}, J=6.6 \mathrm{~Hz}, 6 \mathrm{H}) ; 1.26(\mathrm{~m}, 52 \mathrm{H}) ; 1.58(\mathrm{~d}, J=5.2 \mathrm{~Hz}, 3 \mathrm{H}) ; 1.68$ (tt, $\left.J_{1}=J_{2}=6.8 \mathrm{~Hz}, 4 \mathrm{H}\right) ; 2.00(\mathrm{~m}, 8 \mathrm{H}) ; 2.28(\mathrm{~m}, 2 \mathrm{H}) ; 3.49(\mathrm{~s}, 9 \mathrm{H}) ; 3.81(\mathrm{~m}$,
$2 \mathrm{H}) ; 4.02-4.23(\mathrm{~m}, 6 \mathrm{H}) ; 5.35(\mathrm{~m}, 4 \mathrm{H}) ; 6.35\left(\mathrm{qd}, J_{1}=J_{2}=5.2 \mathrm{~Hz}, 1 \mathrm{H}\right) .{ }^{1} \mathrm{H}-$ NMR (400 MHz, $\left.\mathrm{CDCl}_{3}\right)$ E2 $\delta 0.88(\mathrm{t}, J=6.6 \mathrm{~Hz}, 6 \mathrm{H}) ; 1.26(\mathrm{~m}, 52 \mathrm{H}) ; 1.56$ $(\mathrm{d}, J=5.2 \mathrm{~Hz}, 3 \mathrm{H}) ; 1.67\left(\mathrm{tt}, J_{1}=J_{2}=6.8 \mathrm{~Hz}, 4 \mathrm{H}\right) ; 2.00(\mathrm{~m}, 8 \mathrm{H}) ; 2.28(\mathrm{~m}$, $2 \mathrm{H}) ; 3.49(\mathrm{~s}, 9 \mathrm{H}) ; 3.81(\mathrm{~m}, 2 \mathrm{H}) ; 4.02-4.23(\mathrm{~m}, 6 \mathrm{H}) ; 5.33(\mathrm{~m}, 4 \mathrm{H}) ; 6.41$ (qd, $\left.J_{1}=J_{2}=5.2 \mathrm{~Hz}, 1 \mathrm{H}\right) .{ }^{13} \mathrm{C}-\mathrm{NMR} \delta\left(100.7 \mathrm{MHz}, \mathrm{CDCl}_{3}\right) \mathrm{E} 1 \delta 14.3(2 \mathrm{C}) ; 21.6$; 22.8 (2C); 24.5; 25.5; 25.8; 27.4 (4C); 28.7; 29.3; 29.4 (2C); 29.5 (6C); 29.6 (3C); 29.7 (2C); 29.8 (3C); 29.9 (3C); 30.1; 31.9 (2C); 53.7 (3C); 63.7; $64.3 ; 68.9 ; 69.2 ; 94.7 ; 129.9 ; 130.0 ; 130.1 ; 130.2 ; 153.5 .{ }^{13} \mathrm{C}-\mathrm{NMR} \delta$ (100.7 MHz, CDCl 3 ) E2 $\delta 14.3(2 \mathrm{C}) ; 21.6 ; 22.8$ (2C); 24.5; 25.5; 25.8; 27.4 (4C); 28.8; 29.4 (3C); 29.5 (6C); 29.6 (3C); 29.7 (5C); 29.9 (3C); 30.1; 31.9 (2C); 53.7 (3C); 63.7; 64.3; 69.1 (2C); 94.6; 129.9; 130.0; 130.1; 130.2; 153.3. ${ }^{31} \mathrm{P}-\mathrm{NMR}\left(162 \mathrm{MHz}, \mathrm{CDCl}_{3}\right) \delta-5.00$ (E1); - 5.71 (E2). IR v 512; $721 ; 787 ; 887 ; 969 ; 1032 ; 1259 ; 1392 ; 1465 ; 1757 ; 2852 ; 2921$; 3379. HRMS (ESI+) m/z [M-Cl] calcd for $\mathrm{C}_{49} \mathrm{H}_{97} \mathrm{NO}_{7} \mathrm{P}^{+} 842.6997$, found 842.7005 (E1) and 842.7001 (E2).

\section{3-((((Acetyloxy)methoxy)(erucyloxy)phosphoryl)oxy)-N,N,N-}

trimethylpropan-1-aminium chloride $\left(E_{E_{2}}\right)$. Compound $\mathrm{E}_{\mathrm{E} 2}(8 \mathrm{mg}, 6 \%)$ was obtained from erufosine $(120 \mathrm{mg}, 0.24 \mathrm{mmol})$ and chloromethyl acetate $(215 \mathrm{mg}, 1.91 \mathrm{mmol})$ according to the general procedure. $R_{\mathrm{f}}: 0.15$ $\left(\mathrm{CH}_{2} \mathrm{Cl}_{2} / \mathrm{MeOH} / \mathrm{H}_{2} \mathrm{O}\right.$ 75:22:3). ${ }^{1} \mathrm{H}-\mathrm{NMR}\left(400 \mathrm{MHz}, \mathrm{CD}_{3} \mathrm{OD} / \mathrm{CDCl}_{3}\right.$ 1:1) $\delta$ $0.85(\mathrm{t}, J=6.8 \mathrm{~Hz}, 3 \mathrm{H}) ; 1.25(\mathrm{~m}, 30 \mathrm{H}) ; 1.68\left(\mathrm{tt}, J_{1}=J_{2}=7.2 \mathrm{~Hz}, 2 \mathrm{H}\right) ; 2.01$ $(\mathrm{m}, 4 \mathrm{H}) ; 2.14(\mathrm{~s}, 3 \mathrm{H}) ; 2.19(\mathrm{~m}, 2 \mathrm{H}) ; 3.17(\mathrm{~s}, 9 \mathrm{H}) ; 3.49(\mathrm{~m}, 2 \mathrm{H}) ; 4.07(\mathrm{td}$, $\left.J_{1}=J_{2}=6.9 \mathrm{~Hz}, 2 \mathrm{H}\right) ; 4.18(\mathrm{~m}, 2 \mathrm{H}) ; 5.31(\mathrm{~m}, 2 \mathrm{H}) ; 5.60$ (ABX syst., $\left.J_{A B}=5.6 \mathrm{~Hz}, J_{A X}=13.4 \mathrm{~Hz}, J_{B X}=12.2 \mathrm{~Hz}, 2 \mathrm{H}\right) .{ }^{13} \mathrm{C}-\mathrm{NMR} \delta(100.7 \mathrm{MHz}$, $\left.\mathrm{CD}_{3} \mathrm{OD} / \mathrm{CDCl}_{3} 1: 1\right) \delta 14.5 ; 20.9 ; 23.2 ; 24.8 ; 26.0 ; 27.8(2 \mathrm{C}) ; 29.9 ; 30.0$ (2C); 30.2 (3C); 30.3 (4C); 30.4 (2C); 30.9; 32.6; 53.7 (3C); 64.3; 65.5; 69.8; 83.4; 130.5 (2C); 171.8. ${ }^{31} \mathrm{P}-\mathrm{NMR}\left(162 \mathrm{MHz}, \mathrm{CD}_{3} \mathrm{OD} / \mathrm{CDCl}_{3} 1: 1\right) \delta$ - 3.43. IR v 671; 975; 1033; 1120; 1463; 1767; 2852; 2922; 3366. HR-MS $(\mathrm{ESI}+) \mathrm{m} / \mathrm{z}[\mathrm{M}-\mathrm{Cl}]^{+}$calcd for $\mathrm{C}_{31} \mathrm{H}_{63} \mathrm{NO}_{6} \mathrm{P}^{+} 576.4388$, found 576.4390 .

\section{3-(((Erucyloxy)((hexanoyloxy)methoxy)phosphoryl)oxy)-N,N,N-} trimethylpropan-1-aminium chloride $\left(\boldsymbol{E}_{\mathrm{E} 6}\right)$. Compound $\mathbf{E}_{\mathrm{E} 6}(47 \mathrm{mg}, 30 \%)$ was obtained from erufosine $(120 \mathrm{mg}, 0.24 \mathrm{mmol})$ and chloromethyl hexanoate $(315 \mathrm{mg}, 1.89 \mathrm{mmol})$ according to the general procedure. $R_{\mathrm{f}}$ : $0.3\left(\mathrm{CH}_{2} \mathrm{Cl}_{2} / \mathrm{MeOH} / \mathrm{H}_{2} \mathrm{O}\right.$ 75:22:3). ${ }^{1} \mathrm{H}-\mathrm{NMR}\left(400 \mathrm{MHz}, \mathrm{CD}_{3} \mathrm{OD} / \mathrm{CDCl}_{3} 1: 1\right)$ $\delta 0.85(\mathrm{t}, J=6.8 \mathrm{~Hz}, 3 \mathrm{H}) ; 0.88(\mathrm{t}, J=6.6 \mathrm{~Hz}, 3 \mathrm{H}) ; 1.25(\mathrm{~m}, 34 \mathrm{H}) ; 1.63$ (tt, $\left.J_{1}=J_{2}=6.8 \mathrm{~Hz}, 2 \mathrm{H}\right) ; 1.68\left(\mathrm{tt}, J_{1}=J_{2}=7.2 \mathrm{~Hz}, 2 \mathrm{H}\right) ; 2.01(\mathrm{~m}, 4 \mathrm{H}) ; 2.19(\mathrm{~m}$, $2 \mathrm{H}) ; 2.41(\mathrm{t}, J=7.5 \mathrm{~Hz}, 2 \mathrm{H}) ; 3.17(\mathrm{~s}, 9 \mathrm{H}) ; 3.49(\mathrm{~m}, 2 \mathrm{H}) ; 4.09\left(\mathrm{td}, J_{1}=J_{2}=\right.$ $6.9 \mathrm{~Hz}, 2 \mathrm{H}$ ); $4.20\left(\mathrm{td}, \mathrm{J}_{1}=\mathrm{J}_{2}=6.9 \mathrm{~Hz}, 2 \mathrm{H}\right) ; 5.30(\mathrm{~m}, 2 \mathrm{H}$ ); 5.63 (ABX syst., $\left.J_{A B}=5.2 \mathrm{~Hz}, J_{A X}=13.5 \mathrm{~Hz}, J_{B X}=11.7 \mathrm{~Hz}, 2 \mathrm{H}\right) .{ }^{13} \mathrm{C}-\mathrm{NMR} \delta(100.7 \mathrm{MHz}$, $\left.\mathrm{CD}_{3} \mathrm{OD} / \mathrm{CDCl}_{3} 1: 1\right) \delta 14.2 ; 14.4 ; 22.8 ; 23.2 ; 24.6 ; 24.7 ; 25.9 ; 27.7(2 \mathrm{C})$; 29.7; 29.8 (3C); 30.0 (3C); 30.1; 30.2 (2C); 30.3 (2C); 30.8; 31.7; 32.4; 34.3; 53.7 (3C); 64.1; 65.2; 69.7; 83.2; 130.4 (2C); 173.0. ${ }^{31}$ P-NMR (162 $\left.\mathrm{MHz}, \mathrm{CD}_{3} \mathrm{OD} / \mathrm{CDCl}_{3} 1: 1\right) \delta-3.41 . \mathrm{IR} v 493 ; 755 ; 857 ; 970 ; 1028 ; 1157$; $1269 ; 1465 ; 1760 ; 2852 ; 2922 ; 3372$. HR-MS (ESI+) m/z [M-Cl] ${ }^{+}$calcd for $\mathrm{C}_{35} \mathrm{H}_{71} \mathrm{NO}_{6} \mathrm{P}^{+} 632.5014$, found 632.5009 .

\section{3-(((Erucyloxy))((octanoyloxy)methoxy)phosphoryl)oxy)-N,N,N-} trimethylpropan-1-aminium chloride $\left(E_{E 8}\right)$. Compound $\mathbf{E}_{\mathrm{E} 8}(192 \mathrm{mg}, 69 \%)$ was obtained from erufosine $(202 \mathrm{mg}, 0.40 \mathrm{mmol})$ and chloromethyl octanoate $(620 \mathrm{mg}, 3.22 \mathrm{mmol})$ according to the general procedure. $R_{\mathrm{f}}$ : $0.35\left(\mathrm{CH}_{2} \mathrm{Cl}_{2} / \mathrm{MeOH} / \mathrm{H}_{2} \mathrm{O} 75: 22: 3\right) .{ }^{1} \mathrm{H}-\mathrm{NMR}\left(400 \mathrm{MHz}, \mathrm{CD}_{3} \mathrm{OD} / \mathrm{CDCl}_{3} 1: 1\right)$ $\delta 0.86(\mathrm{t}, J=6.8 \mathrm{~Hz}, 6 \mathrm{H}) ; 1.26(\mathrm{~m}, 38 \mathrm{H}) ; 1.63\left(\mathrm{tt}, J_{1}=J_{2}=6.8 \mathrm{~Hz}, 2 \mathrm{H}\right)$; $1.68\left(\mathrm{tt}, J_{1}=J_{2}=7.4 \mathrm{~Hz}, 2 \mathrm{H}\right) ; 2.01(\mathrm{~m}, 4 \mathrm{H}) ; 2.19(\mathrm{~m}, 2 \mathrm{H}) ; 2.41(\mathrm{t}$, $J=7.5 \mathrm{~Hz}, 2 \mathrm{H}) ; 3.17(\mathrm{~s}, 9 \mathrm{H}) ; 3.49(\mathrm{~m}, 2 \mathrm{H}) ; 4.09\left(\mathrm{td}, J_{1}=J_{2}=6.9 \mathrm{~Hz}, 2 \mathrm{H}\right)$; 4.20 (td, $\left.J_{1}=J_{2}=6.9 \mathrm{~Hz}, 2 \mathrm{H}\right) ; 5.32(\mathrm{~m}, 2 \mathrm{H}) ; 5.63$ (ABX syst.; $J_{A B}=5.2 \mathrm{~Hz}$, $\left.J_{A X}=13.8 \mathrm{~Hz}, J_{B X}=11.1 \mathrm{~Hz}, 2 \mathrm{H}\right) .{ }^{13} \mathrm{C}-\mathrm{NMR} \delta\left(100.7 \mathrm{MHz}, \mathrm{CD}_{3} \mathrm{OD} / \mathrm{CDCl}_{3}\right.$ 1:1) $\delta 14.4 ; 14.5 ; 23.2 ; 23.3 ; 24.7 ; 25.2 ; 26.1 ; 27.8$ (2C); 29.7 (2C); 29.9; 30.0 (3C); 30.2 (3C); $30.3(3 \mathrm{C}) ; 30.4(2 \mathrm{C}) ; 30.9 ; 32.4 ; 32.6 ; 34.5 ; 53.7$ (3C); 64.3; 65.5; 69.9; 83.4; 130.5; 130.6; 173.2. ${ }^{31} \mathrm{P}-\mathrm{NMR}(162 \mathrm{MHz}$, $\left.\mathrm{CD}_{3} \mathrm{OD} / \mathrm{CDCl}_{3} 1: 1\right) \delta-3.50$. IR $v$ 506; 756; 858; $970 ; 1028 ; 1152 ; 1269$; 1466; 1760; 2852; 2922; 3384. HR-MS (ESI+) m/z [M-Cl] calcd for $\mathrm{C}_{37} \mathrm{H}_{75} \mathrm{NO}_{6} \mathrm{P}^{+} 660.5327$, found 660.5317 . 
3-((((Decanoyloxy)methoxy)(erucyloxy)phosphoryl)oxy)-N,N,N-

trimethylpropan-1-aminium chloride $\left(E_{E 10}\right)$. Compound $E_{E 10}(220 \mathrm{mg}$, $74 \%$ ) was obtained from erufosine ( $206 \mathrm{mg}, 0.41 \mathrm{mmol}$ ) and chloromethyl decanoate $(716 \mathrm{mg}, 3.27 \mathrm{mmol})$ according to the general procedure. $R_{\mathrm{f}}$ : $0.45\left(\mathrm{CH}_{2} \mathrm{Cl}_{2} / \mathrm{MeOH} / \mathrm{H}_{2} \mathrm{O}\right.$ 75:22:3). ${ }^{1} \mathrm{H}-\mathrm{NMR}\left(400 \mathrm{MHz}, \mathrm{CD}_{3} \mathrm{OD} / \mathrm{CDCl}_{3} 1: 1\right)$ $\delta 0.86(\mathrm{t}, J=6.8 \mathrm{~Hz}, 6 \mathrm{H}) ; 1.25(\mathrm{~m}, 42 \mathrm{H}) ; 1.63\left(\mathrm{tt}, J_{1}=J_{2}=6.8 \mathrm{~Hz}, 2 \mathrm{H}\right)$; $1.68\left(\mathrm{tt}, J_{1}=J_{2}=7.4 \mathrm{~Hz}, 2 \mathrm{H}\right) ; 2.01(\mathrm{~m}, 4 \mathrm{H}) ; 2.19(\mathrm{~m}, 2 \mathrm{H}) ; 2.41(\mathrm{t}$, $J=7.5 \mathrm{~Hz}, 2 \mathrm{H}) ; 3.17(\mathrm{~s}, 9 \mathrm{H}) ; 3.49(\mathrm{~m}, 2 \mathrm{H}) ; 4.09\left(\mathrm{td}, J_{1}=J_{2}=6.9 \mathrm{~Hz}, 2 \mathrm{H}\right)$; $4.20\left(\mathrm{td}, J_{1}=J_{2}=6.9 \mathrm{~Hz}, 2 \mathrm{H}\right) ; 5.32(\mathrm{~m}, 2 \mathrm{H}) ; 5.63$ (ABX syst., $J_{A B}=5.2 \mathrm{~Hz}$, $\left.J_{A X}=13.8 \mathrm{~Hz}, J_{B X}=11.1 \mathrm{~Hz}, 2 \mathrm{H}\right) .{ }^{13} \mathrm{C}-\mathrm{NMR} \delta\left(100.7 \mathrm{MHz}, \mathrm{CD}_{3} \mathrm{OD} / \mathrm{CDCl}_{3}\right.$ 1:1) $\delta 14.6$ (2C); 23.6 (2C); 25.1; 25.5; 26.4; 28.1 (2C); 30.0; 30.2 (3C); $30.3(3 \mathrm{C}) ; 30.4(2 \mathrm{C}) ; 30.5(2 \mathrm{C}) ; 30.6(3 \mathrm{C}) ; 30.7$ (2C); 31.2; 32.9 (2C); 34.8 ; 53.9 (3C); 64.5; 66.0; 70.1; 83.8; 130.8 (2C); 173.6. ${ }^{31} \mathrm{P}-\mathrm{NMR}(162 \mathrm{MHz}$, $\left.\mathrm{CD}_{3} \mathrm{OD} / \mathrm{CDCl}_{3} 1: 1\right) \delta-3.17$. IR v $512 ; 752 ; 787 ; 858 ; 970 ; 1027 ; 1149$; 1273; 1466; 1761; 2852; 2922; 3373. HR-MS (ESI+) m/z [M-Cl] calcd for $\mathrm{C}_{39} \mathrm{H}_{79} \mathrm{NO}_{6} \mathrm{P}^{+} 688.5640$, found 688.5632 .

3-(((Erucyloxy)((tetradecanoyloxy)methoxy)phosphoryl)oxy)-N,N,Ntrimethylpropan-1-aminium chloride (EE14). Compound $\mathrm{E}_{\mathrm{E} 14}(100 \mathrm{mg}$, $32 \%$ ) was obtained from erufosine $(200 \mathrm{mg}, 0.40 \mathrm{mmol})$ and chloromethyl tetradecanoate $(890 \mathrm{mg}, 3.21 \mathrm{mmol})$ according to the general procedure. $R_{\mathrm{f}}: 0.5\left(\mathrm{CH}_{2} \mathrm{Cl}_{2} / \mathrm{MeOH} / \mathrm{H}_{2} \mathrm{O} 75: 22: 3\right) .{ }^{1} \mathrm{H}-\mathrm{NMR}\left(400 \mathrm{MHz}, \mathrm{CD}_{3} \mathrm{OD} / \mathrm{CDCl}_{3}\right.$ 1:1) $\delta 0.86(\mathrm{t}, J=6.8 \mathrm{~Hz}, 6 \mathrm{H}) ; 1.25(\mathrm{~m}, 50 \mathrm{H}) ; 1.63\left(\mathrm{tt}, J_{1}=J_{2}=6.8 \mathrm{~Hz}, 2 \mathrm{H}\right)$; $1.68\left(\mathrm{tt}, J_{1}=J_{2}=7.4 \mathrm{~Hz}, 2 \mathrm{H}\right) ; 2.01(\mathrm{~m}, 4 \mathrm{H}) ; 2.19(\mathrm{~m}, 2 \mathrm{H}) ; 2.41(\mathrm{t}$, $J=7.5 \mathrm{~Hz}, 2 \mathrm{H}) ; 3.17(\mathrm{~s}, 9 \mathrm{H}) ; 3.49(\mathrm{~m}, 2 \mathrm{H}) ; 4.09\left(\mathrm{td}, J_{1}=J_{2}=6.9 \mathrm{~Hz}, 2 \mathrm{H}\right)$; $4.20\left(\mathrm{td}, \mathrm{J}_{1}=\mathrm{J}_{2}=6.9 \mathrm{~Hz}, 2 \mathrm{H}\right) ; 5.32(\mathrm{~m}, 2 \mathrm{H}) ; 5.63$ (ABX syst., $J_{A B}=5.2 \mathrm{~Hz}$, $\left.J_{A X}=13.8 \mathrm{~Hz}, J_{B X}=11.1 \mathrm{~Hz}, 2 \mathrm{H}\right) .{ }^{13} \mathrm{C}-\mathrm{NMR} \delta\left(100.7 \mathrm{MHz}, \mathrm{CD}_{3} \mathrm{OD} / \mathrm{CDCl}_{3}\right.$ 1:1) $\delta 14.5$ (2C); 23.4 (2C); 24.9; 25.3; 26.2; 27.9 (2C); 29.8; 29.9; 30.0 (2C); 30.1 (2C); $30.3(4 \mathrm{C}) ; 30.6(8 \mathrm{C}) ; 30.5(2 \mathrm{C}) ; 31.0 ; 32.7(2 \mathrm{C}) ; 34.6 ; 53.7$ (3C); 64.3; 65.6; 70.0; 83.5; $130.6(2 \mathrm{C}) ; 173.3$. ${ }^{31} \mathrm{P}-\mathrm{NMR}(162 \mathrm{MHz}$, $\left.\mathrm{CD}_{3} \mathrm{OD} / \mathrm{CDCl}_{3} 1: 1\right) \delta-3.29$. IR v $515 ; 721 ; 772 ; 859 ; 966 ; 1030 ; 1160$; 1269; 1467; 1760; 2849; 2918; 2956; 3395. HR-MS (ESI+) m/z [M-Cl] ${ }^{+}$ calcd for $\mathrm{C}_{43} \mathrm{H}_{87} \mathrm{NO}_{6} \mathrm{P}^{+} 744.6266$, found 744.6259 .

\section{3-(((Erucyloxy))((hexadecanoyloxy)methoxy)phosphoryl)oxy)-N,N,N-} trimethylpropan-1-aminium chloride ( $\left.E_{E 16}\right)$. Compound $E_{E 16}(237 \mathrm{mg}$, $74 \%$ ) was obtained from erufosine (200 $\mathrm{mg}, 0.40 \mathrm{mmol}$ ) and chloromethyl hexadecanoate $(980 \mathrm{mg}, 3.21 \mathrm{mmol})$ according to the general procedure. $R_{\mathrm{f}}: 0.45\left(\mathrm{CH}_{2} \mathrm{Cl}_{2} / \mathrm{MeOH} / \mathrm{H}_{2} \mathrm{O} 75: 22: 3\right) .{ }^{1} \mathrm{H}-\mathrm{NMR}\left(400 \mathrm{MHz}, \mathrm{CD}_{3} \mathrm{OD} / \mathrm{CDCl}_{3}\right.$ 1:1) $\delta 0.86(\mathrm{t}, J=6.8 \mathrm{~Hz}, 6 \mathrm{H}) ; 1.24(\mathrm{~m}, 54 \mathrm{H}) ; 1.63\left(\mathrm{tt}, J_{1}=J_{2}=6.8 \mathrm{~Hz}, 2 \mathrm{H}\right)$; $1.68\left(\mathrm{tt}, J_{1}=J_{2}=7.4 \mathrm{~Hz}, 2 \mathrm{H}\right) ; 2.01(\mathrm{~m}, 4 \mathrm{H}) ; 2.19(\mathrm{~m}, 2 \mathrm{H}) ; 2.41(\mathrm{t}$, $J=7.5 \mathrm{~Hz}, 2 \mathrm{H}) ; 3.17(\mathrm{~s}, 9 \mathrm{H}) ; 3.49(\mathrm{~m}, 2 \mathrm{H}) ; 4.09\left(\mathrm{td}, J_{1}=J_{2}=6.9 \mathrm{~Hz}, 2 \mathrm{H}\right)$; $4.20\left(\mathrm{td}, J_{1}=J_{2}=6.9 \mathrm{~Hz}, 2 \mathrm{H}\right) ; 5.32(\mathrm{~m}, 2 \mathrm{H}) ; 5.63$ (ABX syst., $J_{A B}=5.2 \mathrm{~Hz}$, $\left.J_{A X}=13.8 \mathrm{~Hz}, J_{B X}=11.1 \mathrm{~Hz}, 2 \mathrm{H}\right) .{ }^{13} \mathrm{C}-\mathrm{NMR} \delta\left(100.7 \mathrm{MHz}, \mathrm{CD}_{3} \mathrm{OD} / \mathrm{CDCl}_{3}\right.$ 1:1) $\delta 14.5$ (2C); 23.3 (2C); 24.8; 25.2; 26.1; 27.8 (2C); 29.7; 29.8; 30.0 (6C); 30.2 (4C); 30.3 (8C); 30.4 (2C); 30.9; $32.6(2 \mathrm{C}) ; 34.5 ; 53.7$ (3C); $64.3 ; 65.4 ; 69.9 ; 83.4 ; 130.5$ (2C); 173.2. ${ }^{31} \mathrm{P}-\mathrm{NMR}$ (162 MHz, $\left.\mathrm{CD}_{3} \mathrm{OD} / \mathrm{CDCl}_{3} 1: 1\right) \delta-3.34$. IR v 506; 720; 758; 859; 969; 1021; 1159; $1272 ; 1467 ; 1760 ; 2850 ; 2918 ; 3379$. HR-MS (ESI+) m/z [M-Cl] ${ }^{+}$calcd for $\mathrm{C}_{45} \mathrm{H}_{91} \mathrm{NO}_{6} \mathrm{P}^{+} 772.6579$, found 772.6569 .

3-(((Erucyloxy))((octadecanoyloxy)methoxy)phosphoryl)oxy)-N,N,Ntrimethylpropan-1-aminium chloride $\left(E_{\mathrm{E} 18}\right)$. Compound $\mathrm{E}_{\mathrm{E} 18}(91 \mathrm{mg}, 55 \%)$ was obtained from erufosine $(100 \mathrm{mg}, 0.20 \mathrm{mmol})$ and chloromethyl octadecanoate $(530 \mathrm{mg}, 1.59 \mathrm{mmol})$ according to the general procedure. $R_{\mathrm{f}}: 0.5\left(\mathrm{CH}_{2} \mathrm{Cl}_{2} / \mathrm{MeOH} / \mathrm{H}_{2} \mathrm{O} 75: 22: 3\right) .{ }^{1} \mathrm{H}-\mathrm{NMR}\left(400 \mathrm{MHz}, \mathrm{CD}_{3} \mathrm{OD} / \mathrm{CDCl}_{3}\right.$ 1:1) $\delta 0.88(\mathrm{t}, J=6.8 \mathrm{~Hz}, 6 \mathrm{H}) ; 1.24(\mathrm{~m}, 58 \mathrm{H}) ; 1.62\left(\mathrm{tt}, J_{1}=J_{2}=6.8 \mathrm{~Hz}, 2 \mathrm{H}\right)$; 1.68 (tt, $\left.J_{1}=J_{2}=7.4 \mathrm{~Hz}, 2 \mathrm{H}\right) ; 2.00(\mathrm{~m}, 4 \mathrm{H}) ; 2.28(\mathrm{~m}, 2 \mathrm{H}) ; 2.38(\mathrm{t}, J=7.5$ $\mathrm{Hz}, 2 \mathrm{H}) ; 3.47(\mathrm{~s}, 9 \mathrm{H}) ; 3.80(\mathrm{~m}, 2 \mathrm{H}) ; 4.05\left(\mathrm{td}, \mathrm{J}_{1}=\mathrm{J}_{2}=6.9 \mathrm{~Hz}, 2 \mathrm{H}\right) ; 4.23(\mathrm{~m}$, $2 \mathrm{H}) ; \quad 5.34(\mathrm{~m}, \quad 2 \mathrm{H}) ; \quad 5.63\left(\mathrm{ABX}\right.$ syst., $J_{A B}=4.8 \mathrm{~Hz}, \quad J_{A X}=12.9 \mathrm{~Hz}$, $\left.J_{B X}=11.1 \mathrm{~Hz}, 2 \mathrm{H}\right) .{ }^{13} \mathrm{C}-\mathrm{NMR} \delta\left(100.7 \mathrm{MHz}, \mathrm{CD}_{3} \mathrm{OD} / \mathrm{CDCl}_{3} 1: 1\right) \delta 14.3$ (2C); 22.8 (2C); 24.5; 24.7; 25.5; 27.4 (2C); 29.2; 29.3; 29.4; 29.5 (4C); 29.7 (3C); 29.8 (6C); 29.9 (6C); 30.0 (2C); 30.4; 32.0 (2C); 34.1; 53.8 (3C); $63.7 ; 64.6 ; 69.1 ; 82.7 ; 130.0$ (2C); 172.4. ${ }^{31} \mathrm{P}-\mathrm{NMR}$ (162 MHz,
$\left.\mathrm{CD}_{3} \mathrm{OD} / \mathrm{CDCl}_{3} 1: 1\right) \delta-3.29$. IR $v 508 ; 721 ; 771 ; 859 ; 967 ; 1032 ; 1161$; $1267 ; 1467 ; 1761 ; 2849 ; 2917 ; 3377$. HR-MS (ESI+) m/z [M-Cl] ${ }^{+}$calcd for $\mathrm{C}_{47} \mathrm{H}_{95} \mathrm{NO}_{6} \mathrm{P}^{+} 800.6892$, found 800.6891 .

\section{Methods}

Nucleic acid retardation assay. Freshly prepared lipoplexes (vide infra) at the desired N/P ratio (where $N$ is the concentration of the lipid ammonium group and $\mathrm{P}$ that of nucleic acid phosphate) were analyzed by electrophoresis through a $1 \%$ agarose gel. The gel was run in a $40 \mathrm{mM}$ Tris-acetate-EDTA buffer, $\mathrm{pH} 8.0$ and nucleic acid was further stained using an ethidium bromide solution $(0.5 \mu \mathrm{g} / \mathrm{mL})$.

Dynamic light scattering (DLS) measurements. The average particle size and zeta potential of lipoplexes were measured using a Zetasizer nanoZS apparatus (Malvern Instruments, Paris, France). All measurements were performed on freshly prepared lipoplexes (vide infra) at $25{ }^{\circ} \mathrm{C}$ and in triplicate. Data were analyzed using the multimodal number distribution software supplied with the instrument and expressed as mean $( \pm S D)$.

Erufosine prodrug hydrolytic stability determination. Hydrolysis rate of proAPLs was measured by ${ }^{31} \mathrm{P}-\mathrm{NMR}$ spectroscopy. Compounds were formulated as liposomes using a solvent injection technique. ${ }^{[23]}$ Briefly, the pro-APLs $(10 \mu \mathrm{mol})$ were dissolved in $i-\mathrm{PrOH}(200 \mu \mathrm{L})$ and then injected with a syringe at a flow rate of approximately $600 \mu \mathrm{L} \mathrm{min}{ }^{-1}$ and a stirring speed of $400 \mathrm{rpm}$ into the appropriate aqueous buffer medium $(300 \mu \mathrm{L}$,

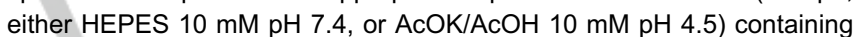
$10 \mathrm{mM}$ Triton $\mathrm{X}-100$. The resulting preparations were complemented with buffer $(400 \mu \mathrm{L})$ and $\mathrm{D}_{2} \mathrm{O}(100 \mu \mathrm{L})$ and introduced into 5-mm NMR tubes, and ${ }^{31} \mathrm{P}-\mathrm{NMR}$ spectra were recorded periodically at $20^{\circ} \mathrm{C}$ with a 4 -s pulse cycle for quantitative measurements.

Pro-APLs self-assembly studies. Self-assembly properties of erufosine and pro-APLs were determined using a fluorescent probe technique. ${ }^{[511]]} \mathrm{A}$ lipid film obtained by evaporation in a SpeedVac apparatus for $1 \mathrm{~h}$ of the adequate volume of an ethanolic solution $(2 \mathrm{mM})$ of the selected compound was dispersed in $\mathrm{H}_{2} \mathrm{O}(2 \mathrm{mM})$ and diluted in a concentration range from $2 \mathrm{mM}$ to $2 \mathrm{nM}$. Pyrene $(0.1 \mathrm{mM}$ in DMSO, $10 \mu \mathrm{L}$ ) was added to the samples under vigorous stirring, and the mixtures were incubated in the dark for $30 \mathrm{~min}$ at $25^{\circ} \mathrm{C}$. Fluorescence spectra were then recorded at 350 to $450 \mathrm{~nm}$ with excitation at $330 \mathrm{~nm}$, with a Fluoromax-4 spectrophotometer (Horiba Jobin Yvon). Emission spectral ratio at 375 and $387 \mathrm{~nm}\left(\mathrm{I}_{375} / \mathrm{I}_{387}\right)$ was expressed as the logarithm of concentration, and the concentration above which the molecules spontaneously associate to form micelles or aggregates was graphically determined as the first break point in the fluorescence behavior of pyrene.

Hemolytic activity determination. Red blood cell (RBC) leakage assay was carried out according to a procedure described elsewhere. [[52]] RBC were prepared from defibrinated sheep blood. Briefly, blood sample $(5 \mathrm{~mL})$ was centrifuged at $500 \times \mathrm{g}$ for $5 \mathrm{~min}$. After removal of the yellow upper layer, an equal volume of PBS pH 7.4 was added to the sample, and the mixture was homogenized. This treatment (centrifugation, removal of upper layer, addition of PBS and homogenization) was repeated three times. The last homogenate was diluted to $1 / 25$ in PBS and the resulting suspension of RBCs $(140 \mu \mathrm{L}$ ) was added to lipid samples (vide supra, $10 \mu \mathrm{L}$ ) prepared at increasing concentration (from $45 \mu \mathrm{M}$ to $3 \mathrm{mM}$ ) in 96-well plates. After incubation for 1 or $24 \mathrm{~h}$ at $37^{\circ} \mathrm{C}$ and $5 \% \mathrm{CO}_{2}$, plates were centrifuged at $250 \mathrm{xg}$ for $10 \mathrm{~min}$ to pellet intact RBC and absorbance of the supernatants $(100 \mu \mathrm{L})$ was measured at $450 \mathrm{~nm}$. Hemolysis induced by the compounds was expressed as percent, calculated from negative and $100 \%$ controls, and plotted as a function of lipid concentration. Negative control was obtained on suspensions of RBC in PBS alone. Complete hemolysis 
(100\% control) was obtained by adding Triton $\mathrm{X}-100^{\circledR}(10 \mu \mathrm{M}, 10 \mu \mathrm{L})$ to suspensions of RBC in PBS alone. Lipid concentrations inducing $50 \%$ hemolysis $\left(\mathrm{HC}_{50}\right)$ and the percentage of hemolysis provoked by $200 \mu \mathrm{M}$ of the lipids $\left(\mathrm{HA}_{200}\right)$ were graphically determined from the curve fitted to the data.

Cell culture. All cell lines were grown in culture flasks (Becton-Dickinson) at $37{ }^{\circ} \mathrm{C}$ in a $5 \% \mathrm{CO}_{2}$ humidified chamber. Human lung carcinoma (A549) and bronchial (16HBE) epithelial cells were grown in DMEM/F12 medium containing FBS (10 \%), penicillin (100 units $/ \mathrm{mL})$, streptomycin $(100 \mu \mathrm{g} / \mathrm{mL})$, and Hepes $(5 \mathrm{mM})$. Lung mucoepidermoid carcinoma cells $(\mathrm{H} 292)$ were grown in RPMI 1640 supplemented with FBS (10\%), sodium pyruvate $(1 \mathrm{mM})$, L-glutamine $(2 \mathrm{mM})$, penicillin (100 units $/ \mathrm{mL})$, streptomycin (100 $\mu \mathrm{g} / \mathrm{mL}$ ), and Hepes $(10 \mathrm{mM})$. At confluence, cells were released from flasks with trypsin $\left(0.5 \%\right.$ in PBS), centrifuged $\left(4^{\circ} \mathrm{C}, 5 \mathrm{~min}, 120 \mathrm{~g}\right)$ counted and transferred into 96-well plates (Becton-Dickinson) in $100 \mu \mathrm{L}$ culture medium (A549: 6,000 cells/well; H292: 9,000 cells/well; 16HBE: 12,000 cells/well) for transfection experiments, cytotoxicity assays, or IC $\mathrm{I}_{50}$ determinations. Plates were maintained at $37^{\circ} \mathrm{C}$ in a $5 \% \mathrm{CO}_{2}$ humidified chamber for $24 \mathrm{~h}$ before experiment.

Preparation of lipoplexes. Typically, the appropriate volume of a freshly prepared solution of pro-erufosine compound $(2 \mathrm{mM}$ in $\mathrm{EtOH})$ was deposited at the bottom of a $500 \mu \mathrm{L}$ polyethylene tube and dried under vacuum for $1 \mathrm{~h}$. Then, pCMV-Gluc DNA $(40 \mu \mathrm{L}$ at the required concentration in $5 \%$ glucose, DNA concentration refers to phosphate content) was added to the resulting lipid film. After stirring by vortex for 20 $\mathrm{s}$, the preparation was allowed to stand at it for $30 \mathrm{~min}$ before use.

Transfection experiments. Cells were seeded into 96-well plates (BectonDickinson) at the required density (vide supra) in $100 \mu \mathrm{L}$ of serum containing culture medium. Twenty-four hours later, freshly prepared DNA lipoplexes $(10 \mu \mathrm{L}$, i.e. $0.4 \mu \mathrm{g}$ DNA) were added to the wells and cells were then let to grow in the incubator without further handling for $24 \mathrm{~h}$. Negative control was obtained by adding glucose $5 \%(10 \mu \mathrm{L})$ to the wells instead of lipoplexes. Then, Gaussia luciferase production was measured by monitoring light production on an aliquot of culture supernatant $(20 \mu \mathrm{L}$ of a $1 / 100^{\text {th }}$ dilution of supernatant prepared in non-supplemented culture medium) for $1 \mathrm{sec}$ upon addition of the coelenterazine substrate $(50 \mu \mathrm{L}$, $1.5 \mu \mathrm{M})$ using a luminometer (Berthold Centro LB960 XS, Thoiry, France). Protein content of the culture supernatant was determined using a bicinchoninic acid (BCA) assay and luciferase activity was normalized to protein content (RLU/mg protein). Value for each sample is the mean of a triplicate determination $( \pm S D)$.

Cytotoxicity assay. Mitochondrial activity measurements (MTT assay) was used to assess cytotoxicity of the compounds. Lipid samples were prepared from a lipid film $(3.6 \mu \mathrm{mol}$ of compound evaporated from an ethanolic solution) hydrated with aqueous glucose $5 \%$ and vigorously vortexed for $20 \mathrm{~s}$ before serial dilution in aqueous glucose $5 \%$. Part of the culture medium in the plates prepared the day before $(25 \mu \mathrm{L})$ was removed and replaced by lipid samples $(25 \mu \mathrm{L})$. Negative control was obtained by adding glucose $5 \%$ to the cells instead of lipoplexes. After a 24-h incubation period at $37{ }^{\circ} \mathrm{C}$, culture supernatant was removed, cells were carefully washed with PBS and $0.5 \mathrm{mg} / \mathrm{mL}$ MTT $(100 \mu \mathrm{L})$ in complete culture medium was added. After a 1 -h incubation period at $37^{\circ} \mathrm{C}$, MTT solution was removed and DMSO $(100 \mu \mathrm{L})$ was added to lyse cells and dissolve reduced MTT. Intensity of MTT reduction was then evaluated by measuring absorbance at $492 \mathrm{~nm}$. Viability of cells treated with lipids or lipoplexes was expressed as the percentage of the absorbance measured in untreated cells. Value for each sample is the mean of triplicate determinations $( \pm S D)$. $I C_{50}$ values were determined within the $95 \%$ confidence interval using nonlinear regression analysis with the GraphPad Prism software (GraphPad Software, San Diego, CA, USA).
Analysis of cell TRAIL receptor expression and sensitivity. To assess TRAIL expression, A549, H292, and 16HBE cells ( $10^{6}$ cells) were washed with PBS containing $2 \% \mathrm{FCS}$ and incubated for $4 \mathrm{~h}$ at $4{ }^{\circ} \mathrm{C}$ with a PElabeled monoclonal antibody targeting TRAIL-R1, R2, R3, or R4 according to concentration recommended by the manufacturer. After two washes with PBS-2 \% FCS, TRAIL receptor expression was monitored by flow cytometry (Guava EasyCyteTM, Merck Milipore, Darmstadt, Germany) and data were analyzed with InCyte Software (Merck Milipore).

For determination of cell sensitivity to TRAIL, A549, H292, and 16HBE cells were washed with PBS containing $2 \% \mathrm{FCS}$ and incubated for $4 \mathrm{~h}$ in 96-well plates $(30,000$ cells, $100 \mu \mathrm{L})$ before addition of increasing amounts (in $10 \mu \mathrm{L}$ ) of SPK. After $24 \mathrm{~h}$ incubation at $37^{\circ} \mathrm{C}$, cell viability was determined by MTT assay as described above.

Statistical analysis. All data are presented as the mean \pm standard deviation (SD). Statistical significance between treatments was assessed by one-way analysis of variance (ANOVA) followed by the Dunnett multiple comparison test, using the Kaleidagraph 4.5 software (Synergy Software, Reading, PA, USA). Data were considered as statistically significant for $p$ value less than $0.05\left({ }^{* * *} p<0.001,{ }^{* *} p<0.01,{ }^{*} p<0.05\right)$.

\section{Acknowledgements}

The authors are grateful for financial support to BG from Labex Medalis, Région Alsace, and Alsace contre le Cancer.

Keywords: erufosine $\cdot$ prodrug $\cdot$ gene therapy $\bullet$ chemotherapy $\bullet$ hemolytic toxicity

[1] a) J. de Almeida Pachioni, J. G. Magalhães, E. J. C. Lima, L. de Moura Bueno, J. F. Barbosa, M. M. de Sá and C. O. Rangel-Yagui, J. Pharm. Pharm. Sci. 2013, 16, 742-759; b) P.-A. Jaffrès, C. Gajate, A. M. Bouchet, H. Couthon-Gourvès, A. Chantôme, M. Potier-Cartereau, P. Besson, P. Bougnoux, F. Mollinedo and C. Vandier, Pharmacol. Ther. 2016, 165, 114-131; c) P. Ríos-Marco, C. Marco, X. Gálvez, J. M. Jiménez-López and M. P. Carrasco, Biochim. Biophys. ActaBiomembr. 2017, 1859, 1657-1667.

[2] A. Kostadinova, T. Topouzova-Hristova, A. Momchilova, R. Tzoneva and M. R. Berger in Advances in Protein Chemistry and Structural Biology, Vol. 101 (Ed. R. Donev), 2015, pp. 27-66.

[3] H. Eibl, D. Arnold, H. U. Weltzien and O. Westphal, Liebigs Ann. Chem. 1967, 709, 226-230.

[4] C. Gajate and F. Mollinedo, Curr. Drug Metab. 2002, 3, 491-525.

[5] a) R. Andreesen, M. Modolell, H. U. Weltzien, H. Eibl, H. H. Common, G. W. Löhr and P. G. Munder, Cancer Res. 1978, 38, 3894-3899; b) P. G. Munder, M. Modolell, R. Andreesen, H. U. Weltzien and O. Westphal, Springer Semin Immunopathol. 1979, 2, 187-203.

[6] D. Berkovic, Gen. Pharmacol. 1998, 31, 511-517.

[7] P. Hilgard, T. Klenner, J. Stekar, G. Nössner, B. Kutscher and J. Engel, Eur. J. Cancer 1997, 33, 442-446.

[8] S. R. Vink, J. H. M. Schellens, W. J. van Blitterswijk and M. Verheij, Invest New Drugs 2005, 23, 279-286.

[9] P. G. Richardson, C. Eng, J. Kolesar, T. Hideshima and K. C. Anderson, Expert Opin. Drug Metab. Toxicol. 2012, 8, 623-633.

[10] J. Kötting, M. R. Berger, C. Unger and H. Eibl, Cancer Chemother Pharmacol. 1992, 30, 105-112.

[11] R. G. Bagley, L. Kurtzberg, C. Rouleau, M. Yao and B. A. Teicher, Cancer Chemother. Pharmacol. 2011, 68, 1537-1546.

[12] a) J. C. Bendell, J. Nemunaitis, S. J. Vukelja, C. Hagenstad, L. T. Campos R. C. Hermann, P. Sportelli, L. Gardner and D. A. Richards, J. Clin. Oncol. 2011 29, 4394-4400; b) S. Fu, B. T. Hennessy, C. S. Ng, Z. Ju, K. R. Coombes, J. K Wolf, A. K. Sood, C. F. Levenback, R. L. Coleman, J. J. Kavanagh, D. M. Gershenson, M. Markman, K. Dice, A. Howard, J. Li, Y. Li, K. Stemke-Hale, M. Dyer, E. Atkinson, E. Jackson, V. Kundra, R. Kurzrock, R. C. Bast and G. B. Mills, Gynecol. Oncol. 2012, 126, 47-53; c) I. Gojo, A. Perl, S. Luger, M. R. Baer, K. J. Norsworthy, K. S. Bauer, M. Tidwell, S. Fleckinger, M. Carroll and E. A. 
Sausville, Invest. New Drugs 2013, 31, 1217-1227; d) A. Guidetti, C. CarloStella, S. L. Locatelli, W. Malorni, R. Mortarini, S. Viviani, D. Russo, A. Marchianò, R. Sorasio, A. Dodero, L. Farina, L. Giordano, M. Di Nicola, A Anichini, P. Corradini and A. M. Gianni, Clin. Cancer Res. 2014, 20, 5641-5651 e) P. G. Richardson, J. Wolf, A. Jakubowiak, J. Zonder, S. Lonial, D. Irwin, J. Densmore, A. Krishnan, N. Raje, M. Bar, T. Martin, R. Schlossman, I. M Ghobrial, N. Munshi, J. Laubach, J. Allerton, T. Hideshima, K. Colson, E. Poradosu, L. Gardner, P. Sportelli and K. C. Anderson, J. Clin. Oncol. 2011, 29, 4243-4249.

[13] a) C. Belka, V. Jendrossek, M. Pruschy, S. Vink, M. Verheij and W. Budach Int. J. Radiat. Oncol. Biol. Phys. 2004, 58, 542-554; b) S. R. Vink, W. J. van Blitterswijk, J. H. M. Schellens and M. Verheij, Cancer Treat. Rev. 2007, 33 , 191-202.

[14] R. Zeisig, A. Ress, I. Fichtner and W. Walther, Cancer Gene Ther. 2003, 10, 302-311.

[15] N. Settelen, O. Roch, D. Bock, R. Rooke, S. Braun and O. Meyer, J. Control. Release 2004, 94, 237-244.

[16] H. A. Elrod, Y.-D. Lin, P. Yue, X. Wang, S. Lonial, F. R. Khuri and S.-Y. Sun Mol. Cancer Ther. 2007, 6, 2029-2038.

[17] Z. U. Rehman, I. S. Zuhorn and D. Hoekstra, J. Control. Release 2013, 166 , 46-56.

[18] S. Mukherjee, T. T. Soe and F. R. Maxfield, J. Cell Biol. 1999, 144, 1271-1284

[19] R. L. Juliano, Nucl. Acid Ther. 2018, 28, 3

[20] B. Gaillard, J.-S. Remy, F. Pons and L. Lebeau, submitted.

[21] M. C. Georgieva, S. M. Konstantinov, M. Topashka-Ancheva and M. R. Berger, Cancer Lett. 2002, 182, 163-174.

[22] a) P. Pierrat, A. Casset, P. Didier, D. Kereselidze, M. Lux, F. Pons and L. Lebeau, ChemBioChem 2016, 17, 1771-1783; b) P. Pierrat, A. Casset, D. Kereselidze, M. Lux, F. Pons and L. Lebeau, Macromol. Biosci. 2016, 16, 984989; c) P. Pierrat, G. Creusat, G. Laverny, F. Pons, G. Zuber and L. Lebeau, Chem. Eur. J. 2012, 18, 3835-3839; d) P. Pierrat, D. Kereselidze, M. Lux, L. Lebeau and F. Pons, Int. J. Pharm. 2016, 511, 205-218; e) P. Pierrat, D. Kereselidze, P. Wehrung, G. Zuber, F. Pons and L. Lebeau, Pharm. Res. 2013 30, 1362-1379; f) P. Pierrat, G. Laverny, G. Creusat, P. Wehrung, J.-M. Strub, A. VanDorsselaer, F. Pons, G. Zuber and L. Lebeau, Chem. Eur. J. 2013, 19, 2344-2355.

[23] P. Gentine, A. Bubel, C. Crucifix, L. Bourel-Bonnet and B. Frisch, J. Liposome Res. 2012, 22, 18-30.

[24] N. Dan and D. Danino, Adv. Colloid Interface Sci. 2014, 205, 230-239.

[25] I. S. Zuhorn, U. Bakowsky, E. Polushkin, W. H. Visser, M. C. A. Stuart, J. Engberts and D. Hoekstra, Mol. Ther. 2005, 11, 801-810.

[26] J. Rejman, V. Oberle, I. S. Zuhorn and D. Hoekstra, Biochem. J./ 2004, 377, 159-169.

[27] S. Audouy, G. Molema, L. de Leij and D. Hoekstra, J. Gene Med. 2000, 2, 465-476.

[28] S. E. Han, H. Kang, G. Y. Shim, M. S. Suh, S. J. Kim, J. S. Kim and Y. K. Oh, Int J. Pharm. 2008, 353, 260-269.

[29] a) C. L. Chan, K. K. Ewert, R. N. Majzoub, Y. K. Hwu, K. S. Liang, C. Leal and C. R. Safinya, J. Gene Med. 2014, 16, 84-96; b) O. Zelphati, L. S. Uyechi, L. G. Barron and F. C. Szoka, Biochim. Biophys. Acta 1998, 1390, 119-133; c) L. Li, H. M. Song, K. Luo, B. He, Y. Nie, Y. Yang, Y. Wu and Z. W. Gu, Int. J. Pharm. 2011, 408, 183-190.

[30] a) J. Kötting, N. W. Marschner, W. Neumuller, C. Unger and H. Eibl, Prog. Exp. Tumor Res. 1992, 34, 131-142; b) E. A. M. Fleer, D. Berkovic, C. Unge and H. Eibl, Prog. Exp. Tumor Res. 1992, 34, 33-46.
[31] M. C. Parlato, J. P. Jee, M. Teshite and S. Mecozzi, J. Org. Chem. 2011, $76,6584-6591$.

[32] a) H. Eibl and P. Kaufmann-Kolle, J. Liposome Res. 1995, 5, 131-148; b) F. Schuettauf, K. H. Eibl, S. Thaler, K. Shinoda, R. Rejdak, C. A. May, G. Blatsios and U. Welge-Lussen, Curr. Eye Res. 2005, 30, 813-820.

[33] M. Lukac, M. Mrva, M. Garajova, G. Mojzisova, L. Varinska, J. Mojzis, M. Sabol, J. Kubincova, H. Haragova, F. Ondriska and F. Devinsky, Eur. J. Med. Chem. 2013, 66, 46-55.

[34] a) I. Fichtner, R. Zeisig, H. Naundorf, S. Jungmann, D. Arndt, G. Asongwe, J. A. Double and M. C. Bibby, Breast Cancer Res. Treat. 1994, 32, 269-279; b) P. Kaufmann-Kolle, J. Drevs, M. R. Berger, J. Kotting, N. Marschner, C. Unger and H. Eibl, Cancer Chemother. Pharmacol. 1994, 34, 393-398.

[35] R. Zeisig, S. Jungmann, D. Arndt, A. Schutt and E. Nissen, Anti-Cancer Drugs 1993, 4, 57-64.

[36] T. Mosmann, J. Immunol. Methods 1983, 65, 55-63.

[37] J. M. W. Gee, A. Howell, W. J. Gullick, C. C. Benz, R. L. Sutherland, R. J. Santen, L. A. Martin, F. Ciardiello, W. R. Miller, M. Dowsett, P. Barrett-Lee, J. F. R. Robertson, S. R. Johnston, H. E. Jones, A. E. Wakeling, R. Duncan and R. I. Nicholson, Endocr.-Relat. Cancer 2005, 12, S1-S7.

[38] H. J. Lee, G. L. Zhuang, Y. Cao, P. Du, H. J. Kim and J. Settleman, Cancer Cell 2014, 26, 207-221.

[39] W. Huang, L. Q. Chen, L. Kang, M. J. Jin, P. Sun, X. Xin, Z. G. Gao and Y. H. Bae, Adv. Drug Deliv. Rev. 2017, 115, 82-97.

[40] V. Tsouris, M. K. Joo, S. H. Kim, I. C. Kwon and Y. Y. Won, Biotechnol. Adv. 2014, 32, 1037-1050.

[41] Y. S. Shi, X. Pang, J. Q. Wang and G. Liu, Adv. Healthc. Mater. 2018, 7, 15.

[42] D. Merino, N. Lalaoui, A. Morizot, P. Schneider, E. Solary and O. Micheau, Mol. Cell. Biol. 2006, 26, 7046-7055.

[43] S. Shirley, A. Morizot and O. Micheau, Recent Patents Anti-Canc. Drug Discov. 2011, 6, 311-323.

[44] N. Chekkat, C. M. Lombardo, C. Seguin, M.-C. Lechner, F. Dufour, Y Nominé, M. De Giorgi, B. Frisch, O. Micheau, G. Guichard, D. Altschuh and S. Fournel, Oncotarget 2018, 9, 15566.

[45] K. Azijli, I. A. M. van Roosmalen, J. Smit, S. Pillai, M. Fukushima, S. de Jong, G. J. Peters, I. V. Bijnsdorp and F. A. E. Kruyt, Cancer Chemother. Pharmacol. 2014, 73, 1273-1283.

[46] P. M. Nair, H. Flores, A. Gogineni, S. Marsters, D. A. Lawrence, R. F. Kelley, H. Ngu, M. Sagolla, L. Komuves, R. Bourgon, J. Settleman and A. Ashkenazi, Proc. Natl. Acad. Sci. U. S. A.a 2015, 112, 5679-5684.

[47] L. D. Mayer and A. S. Janoff, Mol. Interv. 2007, 7, 216-223.

[48] L. Lebeau, S. Olland, P. Oudet and C. Mioskowski, Chem. Phys. Lipids 1992, 62, 93-103.

[49] M. Kim, A. Pitchaiah, N.-J. Park, I. T. Hwang and K.-I. Lee, Lett. Org. Chem. 2012, 9, 628-631.

[50] J. A. Heyes, D. Niculescu-Duvaz, R. G. Cooper and C. J. Springer, J. Med. Chem. 2002, 45, 99-114.

[51] a) E. D. Goddard, N. J. Turro, P. L. Kuo and K. P. Ananthapadmanabhan, Langmuir 1985, 1, 352-355; b) L. Piñeiro, M. Novo and W. Al-Soufi, Adv. Colloid Interface Sci. 2015, 215, 1-12.

[52] B. C. Evans, C. E. Nelson, S. S. Yu, K. R. Beavers, A. J. Kim, H. Li, H. M. Nelson, T. D. Giorgio and C. L. Duvall, J. Vis. Exp. 2013, 73, e50166. 
Entry for the Table of Contents (Please choose one layout)

Layout 1:

\section{FULL PAPER}

Text for Table of Contents

Layout 2:

\section{FULL PAPER}

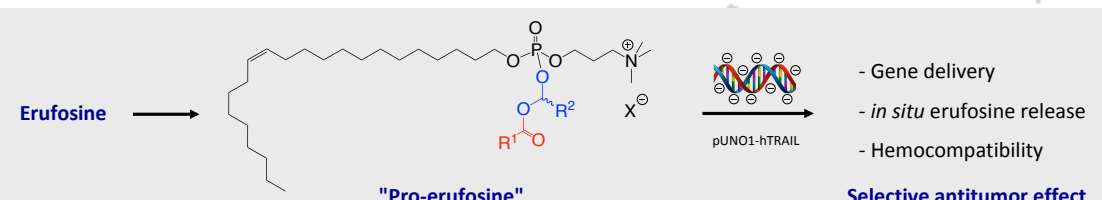

Dual erufosine prodrugs: Biolabile cationic derivatives of the antiproliferative alkylphospholipid erufosine have been synthesized and show combined antitumor activity with a plasmid encoding the tumor necrosis factor-related apoptosisinducing ligand (TRAIL), with selectivity for tumor vs. non-tumor cells.
Author(s), Corresponding Author(s)*

Page No. - Page No.

Title

((Insert TOC Graphic here: $\max$. width: $5.5 \mathrm{~cm}$; max. height: $5.0 \mathrm{~cm})$ )
Boris Gaillard, Cendrine Seguin, JeanSerge Remy, Françoise Pons, Luc Lebeau*

Page No. - Page No.

Erufosine (ErPC3) Cationic Prodrugs as Dual Gene Delivery Reagents for Combined Antitumor Therapy 